FACULDADE DE FILOSOFIA, LETRAS E CIÊNCIAS HUMANAS DEPARTAMENTO DE GEOGRAFIA

PROGRAMA DE PÓS-GRADUAÇÃO EM GEOGRAFIA HUMANA

\title{
ESPECIALIZAÇÃO PRODUTIVA DO TERRITÓRIO E O CIRCUITO ESPACIAL PRODUTIVO DE CELULOSE EM EUNÁPOLIS - BA
}

Carolina Joly

Orientadora: Prof a ${ }^{\mathrm{Dr}}{ }^{\text {a }}$ Maria Mónica Arroyo

Tese apresentada ao programa de Pós-Graduação em Geografia Humana, do Departamento de Geografia da Faculdade de Filosofia, Letras e Ciências Humanas da Universidade de São Paulo, para obtenção do título de Mestre em Geografia.

São Paulo 


\author{
UNIVERSIDADE DE SÃO PAULO \\ FACULDADE DE FILOSOFIA, LETRAS E CIÊNCIAS HUMANAS \\ DEPARTAMENTO DE GEOGRAFIA \\ PROGRAMA DE GEOGRAFIA HUMANA
}

\title{
ESPECIALIZAÇÃO PRODUTIVA DO TERRITÓRIO E O CIRCUITO ESPACIAL PRODUTIVO DE CELULOSE EM EUNÁPOLIS - BA
}

Carolina Joly

Orientadora: Prof a ${ }^{\mathrm{Dr}}{ }^{\text {a }}$ Maria Mónica Arroyo

São Paulo

2007 


\section{DEDICATÓRIA}

Esse trabalho é dedicado aos meus mestres, acadêmicos ou não, que me deram, por um lado, os instrumentos para compreender o mundo, e de outro, o gosto pelo seu questionamento.

A um deles, faço uma dedicatória especial, pois além de meu mestre, é também meu pai, com quem aprendo sempre. 


\section{AgRADECIMENTOS}

Agradeço à FAPESP pela concessão da bolsa de estudos, sem a qual a qualidade desta pesquisa estaria muito diminuída. Agradeço também ao CNPq por ter financiado o trabalho de campo realizado no Espírito Santo, que contribuiu muito para o resultado da pesquisa.

À Mónica minha sincera admiração e carinho, pela sua competência e cumplicidade, inclusive extra-acadêmica.

Aos amigos e colegas do LABOPLAN, pelas boas trocas de referências, experiências e idéias. Valeu!

Aos amigos que foram abrigo, alguns literalmente, quando me hospedaram também em suas casas. Muito obrigada Tomaz, Vovó, Solange, Rita, Camila, Paula, Michele, Paula, Bianca e Vinícius.

Mas é à minha família (Carlos, Lalá, Helô e Soneca) que faço um agradecimento especial, pois o apoio, os conselhos, o carinho e a companhia de vocês foram indispensáveis para que eu chegasse até a conclusão deste trabalho e desta etapa da minha vida. Muito obrigada pela força de sempre. 


\title{
Resumo
}

O presente estudo analisa o processo de inserção do circuito espacial produtivo de celulose na região de Eunápolis, extremo sul da Bahia, através da implantação da empresa Veracel Celulose. Resultado de uma joint-venture entre as empresas Aracruz Celulose e a escandinava Stora Enso, o novo empreendimento conta com uma das maiores plantas industriais do circuito, além de uma área florestal própria, com cerca de cem mil hectares reflorestados, espalhados por dez municípios da região. O trabalho conclui que o recrudescimento da concentração fundiária, implicado pela massiva compra de terras pela empresa, e o grande contingente populacional de migrantes atraídos para Eunápolis com a sua instalação, não são compensados pelos empregos e tributos gerados pela Veracel, trazendo poucas vantagens para quem vivencia a região e o lugar. O discurso do desenvolvimento regional, como conclui a pesquisa, ainda não considera as desigualdades anteriormente impressas no território, ao contrário, só as tem aprofundado.

\begin{abstract}
The present study analyses the insertion of the spatial productive circuit of cellulose in Eunápolis, situated in the extreme south of Bahia state, with the installation of the Veracel Celulose enterprise. Result of a joint venture between Aracruz Celulose and the Scandinavian company Stora Enso, Veracel Celulose is one of the largest industrial plants of the world circuit of cellulose. Its forest area, of approximately a hundred thousand reforested hectares, spreads over ten municipalities of the region. The research shows that land concentration increase, caused by the intensive land purchasing carried out by the company, and the large contingent of migrants attracted to Eunápolis because of its installation, are not compensated by jobs offered and tributes paid by Veracel. So, this large cellulose venture brought little social and economic gains for people living in the region. As a conclusion, we can say that regional development speech still do not consider the inequalities previously imprinted in the territory, on the contrary, it have only deepened them.
\end{abstract}

\section{PALAVRAS-CHAVE / KEY WORDS}

CELULOSE - VERACEL - EUNÁPOLIS-BA - DESENVOLVIMENTO REGIONAL - TERRITÓRIO BRASILEIRO

CELLULOSE - VERACEL - EUNÁPOLIS-BA - REGIONAL DEVELOPMENT - BRAZILIAN TERRITORY 


\section{SUMÁRIO}

Resumo 6

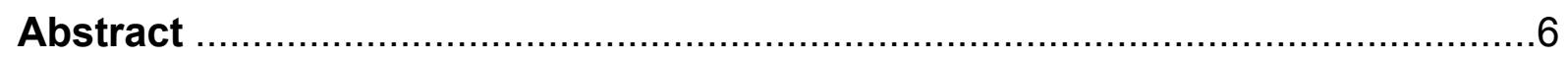

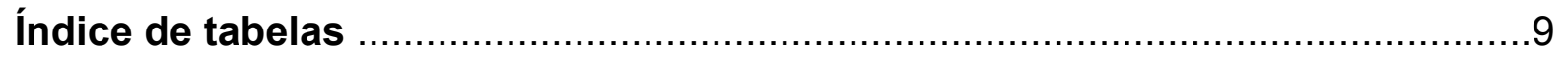

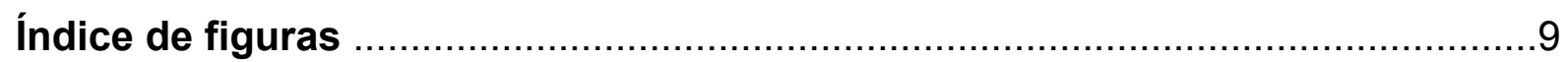

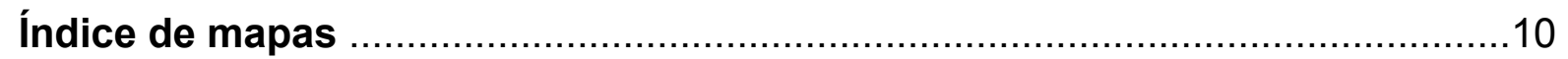

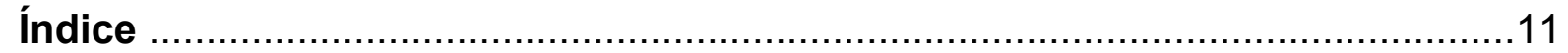

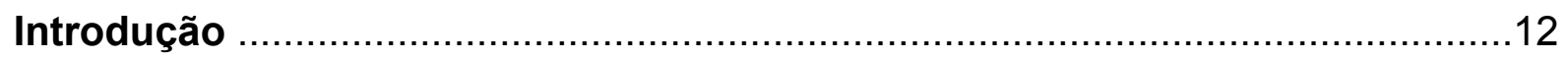

Capítulo 1) O uso do território e especialização produtiva............................14

1.1) O período técnico-científico-informacional e o meio geográfico atual ..........15

1.2) Região, circuito espacial de produção e especialização produtiva do território novos significados para conceitos que permanecem ................................18

1.3) Grandes empresas e a especialização produtiva nos lugares .....................21

Capítulo 2) O circuito espacial produtivo de celulose no território brasileiro e a especialização produtiva do norte do Espírito Santo.......................................27

2.1) origem e consolidação do circuito no país...........................................28

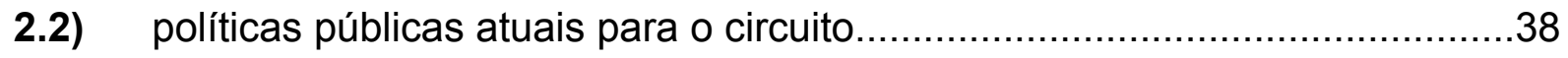

2.3) o papel da sociedade civil organizada contra a expansão da monocultura do

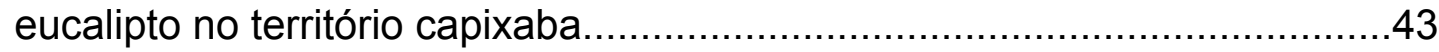

2.4) consolidação da empresa Aracruz Celulose, a especialização produtiva do território capixaba e sua expansão para o sul da Bahia. 
Capítulo 3) A empresa Veracel e a especialização produtiva do território no extremo sul da Bahia - aprofundando contradições

3.1) Mudanças na organização do espaço regional e os principais fatores de atração para o circuito espacial produtivo de celulose 63

3.2) Política territorial da empresa Veracel .74

3.3) Território usado pela Veracel e as principais transformações sócio-espaciais. .86

Considerações finais .90

Referências bibliográficas .94 


\section{ÍNDICE DE TABELAS}

TABELA 1 - ANALFABETISMO FUNCIONAL POR FAIXA ETÁRIA DA POPULAÇÃO..71

TABELA 2 - DISTRIBUIÇÃO DOS FUNCIONÁRIOS DA VERACEL.....................81

TABELA 3 - EVOLUÇÃO POPULACIONAL DE EUNÁPOLIS..............................87

\section{ÍNDICE DE FIGURAS}

FIGURA 1 - NAVIO ATRACADO NO PORTOCEL........................................55

FIgURA 2 - GALPÃO DE ARMAZENAMENTO DO PORTOCEL.........................55

FIgURA 3 - COMPLEXO PRODUTIVO DA ARACRUZ EM BARRA DO RIACHO-ES.56

FIGURA 4 - BARCAÇA ATRACADA NO PORTOCEL.................................59

FIGURA 5 - MÁQUINA DESCARREGA BARCAÇA...................................59

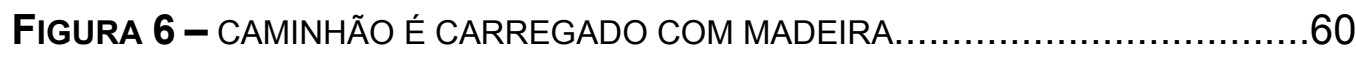

FIgURA 7 - TERMINAL MARÍTIMO DE BELMONTE-BA.............................69

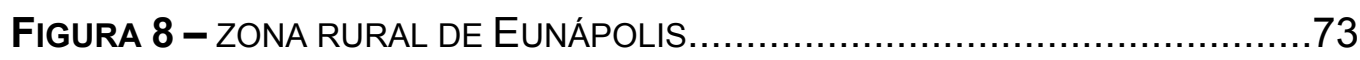

FIGURA 9 - ÁREA DE PLANTIO DA VERACEL.....................................77

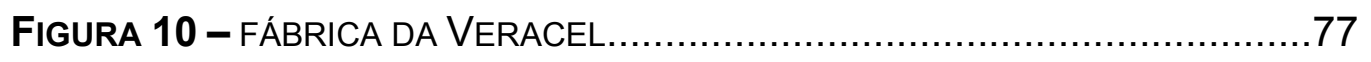

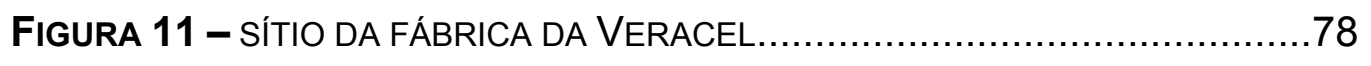

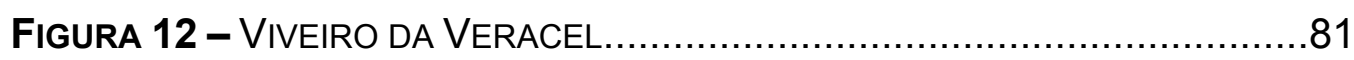

FIGURA 13 - TORAS DE MADEIRA PARA QUEIMA NA FÁBRICA $\ldots \ldots \ldots \ldots \ldots \ldots \ldots . . \ldots 5$

FIgURA 14 - SALA DE CONTROLE OPERACIONAL DA VERACEL....................85

FIGURA 15 - FARDOS DE CELULOSE PRONTOS PARA O EMBARQUE...............86

FIGURA 16 - GRÁFICO INDICA AUMENTO DA CONCENTRAÇÃO FUNDIÁRIA........87 


\section{ÍNDICE DE MAPAS}

MAPA 1- ESPECIALIZAÇÃO PROdUtiVA DE CELULOSE..............................22

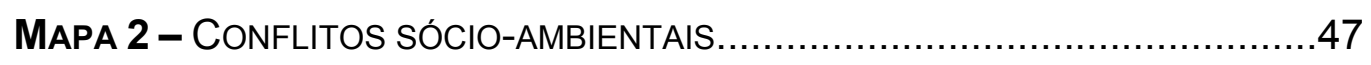

MAPA 3 - FLUXO DE CELULOSE MOVIMENTADO PELO PORTOCEL.................54

MAPA 4 - Topologia dA EMPRESA ARACRUZ Celulose..........................61

MAPA 5 - EXTREMO SUL DA BAHIA E SUAS PRINCIPAIS CIDADES.................64

Mapa 6 - Municípios sob influência da Veracel Celulose..................76 


\section{ÍNDICE}

Introdução 12

Capítulo 1) 0 uso do território e especialização produtiva .14

1.1) o período técnico-científico-informacional e o meio geográfico atual 15

1.2) região, circuito espacial de produção e especialização produtiva do território -novos significados para conceitos que permanecem

1.3) grandes empresas e a especialização produtiva nos lugares .21

Capítulo 2) O circuito espacial produtivo de celulose no território brasileiro e a especialização produtiva do norte do Espírito Santo

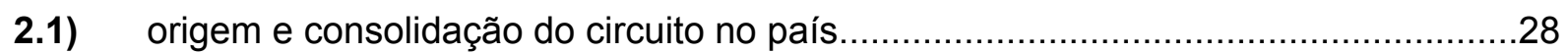

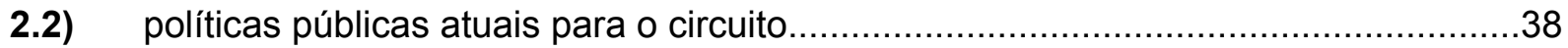

2.3) o papel da sociedade civil organizada contra a expansão da monocultura do eucalipto no território capixaba.

2.4) consolidação da empresa Aracruz Celulose, a especialização produtiva do território capixaba e sua expansão para o sul da Bahia.

Capítulo 3) A empresa Veracel e a especialização produtiva do território no extremo sul da Bahia - aprofundando contradições.

3.1) mudanças na organização do espaço regional e os principais fatores de atração para o circuito espacial produtivo de celulose 63

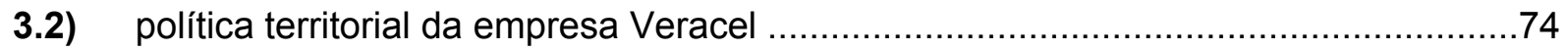

3.3) território usado pela Veracel e as principais transformações sócio-espaciais............86

Considerações finais .90

Referências bibliográficas .94 


\section{Introdução}

O conceito de território usado, criado por Santos (1998), autoriza a análise geográfica apreender não só a materialidade e seus arranjos espaciais, como também o plano das ações, da política, das intencionalidades presentes no bojo das modernizações do atual período.

Quando geografizadas, isto é, espacializadas no território, essas ações qualificam o uso que se faz deste território, como por exemplo, a atuação de um conjunto de empresas que operam em um mesmo circuito espacial produtivo, ou seja, na mesma atividade produtiva. A análise das formas de uso do território onde atua um circuito, pode, por sua vez, nos revelar outro fenômeno espacial, o da especialização produtiva do território, então preparado para servir às empresas do circuito em questão.

A partir do final da década de 70, teve início um franco processo de especialização produtiva do território brasileiro, localizado entre o norte do estado do Espírito Santo e o extremo sul da Bahia. Aí foi instalada uma concentração de grandes empresas ligadas à produção de celulose para exportação, como a Aracruz Celulose e a Bahia Sul Suzano, assim como suas respectivas áreas de floresta, sob forte apoio governamental.

Em 2005, entrou em operação a mais nova empresa produtora de celulose para exportação desta região, a Veracel Celulose, instalada no município de Eunápolis, sul da Bahia. Resultado de uma joint-venture entre a Aracruz Celulose e a sueco-finlandesa Stora Enso, a Veracel possuía, até 2005 , cerca de cem mil hectares de terras reflorestadas, distribuídas entre dez municípios da região.

Esta dissertação, portanto, teve como objetivo investigar em que medida a especialização produtiva de um lugar ou região, como no caso de Eunápolis, a despeito dos empregos e arrecadação tributária gerados, também tem contribuído para aprofundar as desigualdades historicamente constituídas na região, denotando um uso excludente e seletivo do território. A pesquisa constatou que, quanto mais previamente frágil a estrutura sócio-econômica de um lugar ou região, mais negativos serão os desdobramentos das grandes inversões de capital, como as do porte da Veracel, aí instalados. 
A pesquisa teve como embasamento empírico as informações coletadas durante dois trabalhos de campo, realizados em Eunápolis-BA e em Vitória-ES. Ambos se mostraram muito ricos em oportunidades de constatação dos dados aferidos por fontes indiretas de informação, como sites institucionais, publicações científicas e notícias de jornais. A metodologia de pesquisa pôde contar, portanto, com visitas às fábricas da Veracel e da Aracruz Celulose, ao Portocel (único terminal especializado em transporte de celulose do país) e à cidade de Eunápolis propriamente. As entrevistas e observações pessoais, realizadas nos dois trabalhos de campo, foram de fundamental importância para a pesquisa, sem as quais a qualidade do trabalho estaria seriamente comprometida.

A estatística do comércio exterior pode acabar, neste caso, por mascarar mazelas como o aumento da concentração fundiária, o êxodo rural e o desemprego numa das regiões mais desiguais do país. 


\section{Capítulo 1}

\section{Uso do território e especialização produtiva}

Não serei o poeta de um mundo caduco.

Também não cantarei o mundo futuro. Estou preso à vida e olho meus companheiros. Estão taciturnos mas nutrem grandes esperanças.

Entre eles, considero a enorme realidade.

O presente é tão grande, não nos afastemos.

Não nos afastemos muito, vamos de mãos dadas.

(Trecho do poema Mãos Dadas, de Carlos Drummond de Andrade) 
1.1) O PERÍODO TÉCNICO-CIENTÍFICO-INFORMACIONAL E O MEIO GEOGRÁFICO ATUAL

Neste período histórico em que vivemos, assistimos à realização de boa parte das promessas feitas pela humanidade desde o lluminismo, ainda na segunda metade do século XVII, quando nasce a Ciência Moderna. Os ciclos de modernizações sucessivas nos deram cada vez mais liberdade $e$ independência em relação ao chamado meio natural. Essas vagas de modernização se intensificaram após a segunda metade do século $X X$, quando se consolidou a união entre técnica e ciência, nos brindando com tecnologias importantes como a descoberta da energia atômica, o nascimento da engenharia genética e o domínio do espectro eletromagnético. Em pouco mais de duzentos anos, a humanidade conquistou, senão física, pelo menos remotamente, o domínio de todos os rincões da Terra, pois hoje o ecúmeno equivale a todo o planeta.

A chamada totalidade empírica foi, segundo Santos (2000), finalmente concretizada, pois hoje é possível dizer que existe, pela primeira vez na história, um tempo real que une os diversos aconteceres em todos os pontos do globo simultaneamente. Mais do que isso, existe também uma unicidade técnica, que permite a comunicação entre os diferentes lugares do planeta e a verificação desse tempo real, tudo isso através da informação, o novo vetor de modernização do mundo (Santos, 1996).

Através desse movimento modernizante, nosso planeta foi ganhando outra fisionomia, pois as cidades cresceram e os fluxos de toda a natureza aumentaram. Pontes, estradas, linhas férreas, cabos submarinos, prédios, plantações, aeroportos, plataformas de petróleo, pastagens, infovias, torres de celular, represas, gasodutos, etc, se acumularam nas nossas paisagens, e deram ao nosso meio geográfico uma densidade técnico-científica e informacional como nunca houve antes. A soma desses verdadeiros objetos técnicos que hoje compõe as paisagens do globo, garante a circulação dos diferentes fluxos que alimentam o "sistema-mundo" (Braudel, 1979) ${ }^{1}$ como um todo, dando maior ou menor fluidez ao transporte de valores, pessoas, mercadorias, idéias, informação.

\footnotetext{
${ }^{1}$ Apud Santos (1996:128)
} 
Quanto maior a densidade técnico-científica-informacional acumulada pela modernização num determinado território, mais fluido ele se torna. Isso significa que um território equipado com objetos técnicos eficazes (meios de transporte eficientes, boa cobertura dos meios de comunicação, centros de qualificação da mão-de-obra e normas que incentivem a produção) realiza mais rapidamente a transformação da circulação (fluxos) em capital (seja em forma de mercadoria, finanças ou informação). Esse é um dado fundamental que caracteriza o atual período em que vivemos, o período técnico-científicoinformacional (Santos, 1996).

Para Santos (1996),

Como em todas as épocas, o novo não é difundido de maneira generalizada e total. Mas, os objetos técnico-informacionais conhecem uma difusão mais generalizada e mais rápida do que as precedentes famílias de objetos. Por outro lado, sua presença, ainda que pontual, marca a totalidade do espaço. É por isso que estamos considerando o espaço geográfico do mundo atual como um meio técnico-científico-informacional. (Santos, 1996:191)

Contudo, a inserção nesse grau de modernidade, que acompanha a velocidade da informação e da diminuição das distâncias, não ocorre com todos os lugares e pessoas, ao contrário, tornou-se mais um fator de diferenciação, inclusive espacial. A Geografia, no entanto, possui boas ferramentas para tentarmos apreender esse movimento contraditório. Como sugestão de análise teórica dessa realidade, Santos (1994) nos conta como os geógrafos podem entender as transformações que, dialeticamente, insistem em homogeneizar os lugares, mas que na verdade, têm reforçado as diferenças entre eles:

Quando trabalho com o mundo, utilizo todas as suas variáveis em um momento dado. Mas nenhum lugar pode acolher todas nem as mesmas variáveis, nem os mesmo elementos nem as mesmas combinações. Por isso, cada lugar é singular, e uma situação não é semelhante a qualquer outra. Cada lugar combina de maneira particular variáveis que podem, muitas vezes, ser comum a vários lugares. O acontecer global dá-se seletivamente, de modo ímpar, ainda que sempre comandado pela totalidade, e é isso que nos leva imperativamente à necessidade de atentar para a história concreta do hoje, da comunidade humana, sua atualidade, não importa o lugar particular onde o novo se mostre. A teorização depende de um esforço de generalização e de um esforço de individualização. A generalização nos dá a listagem das possibilidades; a individualização nos indica como, em cada lugar, algumas dessas possibilidades se combinam. (Santos, 1994:58)

As modernizações, portanto, não alcançam todos os lugares ao mesmo tempo, pois muitas vezes o velho convive com o novo ou, pelo menos, com a possibilidade do novo. Nos últimos vinte anos, com o fenômeno da globalização, essa densidade técnico-científica-informacional do nosso planeta 
foi ganhando conteúdos cada vez mais seletivos, concentrando em alguns poucos pontos dos territórios o reflexo dessas modernizações.

Os lugares, então, na esperança de poderem abrigar esses modernos objetos técnicos ligados à produção, que na realidade são frutos de investimentos intensivos em capital (como indústrias de ponta, empresas multinacionais, universidades, centros de pesquisa, etc), preparam o seu território para recebê-los, aparelhando-se com a infra-estrutura necessária. Entretanto, a eleição de um lugar para receber esses modernos objetos técnicos têm sido, cada vez mais, pautada não somente pelas condições locais oferecidas, mas também pelo campo da política.

A escolha de Eunápolis, por exemplo, para sediar uma das mais modernas fábricas de celulose do mundo, não foi pautada somente nas boas condições edafo-climáticas da região, ou da sua proximidade com o litoral. Esses fatores contribuíram, de fato, para a escolha do município pela Veracel, mas o apoio político, dado pelas esferas públicas de governo ao investimento multinacional, também pesou na decisão.

O fato da empresa Aracruz Celulose, sócia do investimento da Veracel, já possuir anteriormente terras no sul da Bahia e, além de, na época da implantação do investimento, enfrentar problemas legais para expandir suas áreas de cultivo no seu estado natal (Espírito Santo), influenciaram sim na escolha do sul da Bahia, então visto como uma continuidade natural do norte capixaba. Mas as facilidades oferecidas pelo governo baiano também contribuíram.

Além de ter asfaltado muitas estradas vicinais utilizadas para escoar a produção, ter permitido a construção do terminal portuário exclusivo em uma praia da região e ter isentando a empresa da cobrança pelo uso dos recursos hídricos, retirados de uma bacia hidrográfica interestadual (bacia do rio Jequitinhonha), o órgão de controle agropecuário e florestal baiano (Superintendência de Desenvolvimento Florestal e Unidades de Conservação) deixou de instituir o sistema de cobrança pela madeira que entra na fábrica, por exemplo, ao contrário do órgão equivalente no Espírito Santo. Neste estado, aliás, também foi aprovado, com amplo esforço da sociedade civil organizada, a lei que instituiu o zoneamento agro-ecológico, instrumento legal inexistente na Bahia, que disciplinou as áreas de reflorestamento das empresas no 
Espírito Santo. Além disso, no início da construção da fábrica da Veracel, o prefeito de Eunápolis concedeu um desconto na cobrança de um imposto municipal (ISSQN), mantendo-o no limite mínimo que qualquer prefeitura está autorizada a cobrar (correspondendo a $2 \%$ do faturamento das empresas).

Como é possível perceber, o antigo determinismo geográfico, que costumava explicar a localização de empreendimentos como a Veracel, levando em conta apenas fatores como as condições morfoclimáticas ou a proximidade dos centros consumidores, não é mais suficiente para compreender as escolhas que o capital é capaz de fazer hoje. É preciso considerar, além das possibilidades técnicas disponíveis, também a influência da esfera política nessas escolhas, pois é ela quem, cada vez mais, tem trazido as modernizações do campo da possibilidade para o da realidade dos lugares e das regiões.

Ao mesmo tempo, é bom lembrar que, para abrigar um investimento desse porte, é necessário que o lugar ou a região reúnam condições mínimas de suporte, pois o capital não é tão flexível como aparenta. Eunápolis é o único município da região com centro comercial e rede de serviços (transporte, bancário, manutenção de equipamentos, etc) bem desenvolvido, ocupando uma posição central na hierarquia regional.

\section{2) REGIÃO, CIRCUITO ESPACIAL DE PRODUÇÃO E ESPECIALIZAÇÃO PRODUTIVA DO TERRITÓRIO - NOVOS SIGNIFICADOS PARA CONCEITOS QUE PERMANECEM \\ O edifício regional, por sua vez, também sofreu transformações com o} passar do tempo, perdendo aos poucos o aspecto insular e autônomo para se tornar cada vez mais relacional e interdependente. Essa evolução se deu, principalmente, por conta do aumento gradual e cumulativo da densidade técnica e informacional anexada às regiões do mundo, permitindo o crescimento da circulação de fluxos materiais e imateriais.

Ao longo da história, passamos de uma autonomia relativa entre subespaços a uma interdependência crescente; de uma interação local entre sociedade regional e natureza a uma espécie de socialização capitalista territorialmente ampliada; de circuitos com âmbito local, apenas rompidos por alguns poucos produtos e pouquíssimos produtores, à existência predominante de circuitos mais amplos.(Santos, 1996:203) 
Mesmo a proximidade e a contigüidade, antes condições essenciais para a conformação de uma região, hoje não são mais um pré-requisito. Há lugares, por exemplo, que guardam um nexo regional muito mais forte com outros, fisicamente mais distantes, do que com seus próprios vizinhos. Esse fenômeno é reflexo direto do que Santos (1996) chamou de alargamento dos contextos, referindo-se justamente às transformações sofridas pela ampliação generalizada do campo das relações (comerciais, sociais, políticas, culturais), sobretudo com as novas possibilidades oferecidas pelas tecnologias da informação.

Hoje, a conexão de um lugar ou uma região com o mundo, por exemplo, não precisa, necessariamente, passar pela escala do território nacional. Como se pode perceber, as relações de hierarquia espacial também foram modificadas. Se antes, os campos de influência de uma escala espacial sobre outra seguiam sempre uma linearidade crescente, de acordo com a importância ou a raridade dos serviços e bens de consumo oferecidos pela configuração territorial dos lugares, atualmente as relações inter-escalares podem se dar em diferentes direções, dadas as possibilidades concedidas pelo alargamento. Contudo, como nunca há uniformidade, no que tange às transformações socioespaciais, essas novas relações coexistem com a hierarquia espacial clássica de Christaller (1933), onde as cidades menores se relacionam com os centros regionais e estes, por sua vez, buscam soluções nas metrópoles regionais e nacionais.

Por conta desses novos atributos, chegou-se até a anunciar o fim da região, como recorte espacial e categoria de análise, ocasionado pelas profundas transformações vividas no fim do século passado, que fez com que a antiga configuração regional desmoronasse. Contudo, a região não desapareceu, apenas mudou de conteúdo, agora cada vez mais técnico. Pois hoje, nenhum subespaço escapa ao processo integrado de globalização e fragmentação.

Acostumaram-nos a uma idéia de região como um subespaço longamente elaborado, uma construção estável. Agora, neste mundo globalizado, com a ampliação da divisão internacional do trabalho e o aumento exponencial do intercâmbio, dão-se, paralelamente, uma aceleração do movimento e mudanças mais repetidas, na forma e no conteúdo das regiões. Mas o que faz a região não é a longevidade do edifício, mas a coerência funcional, que a distingue das outras entidades, vizinhas ou não. O fato de ter vida curta não muda a definição do recorte territorial.(Santos, 1996:197) 
O espaço global, portanto, se reorganizou para atender às novas necessidades do processo produtivo, que não conhece mais as fronteiras regionais, territoriais ou culturais. As regiões, na realidade, aparecem como distintas versões da globalização, combinando os vetores modernizantes externos com as potencialidades encontradas localmente. Em decorrência, enquanto se difundem os modernos processos produtivos, a própria produção se especializa regionalmente, fazendo com que as regiões deixem de diversificá-la.

A especialização produtiva das regiões ou dos territórios é reflexo direto do aprofundamento da divisão internacional do trabalho, observado nas últimas décadas. Parte da celulose produzida pela Veracel, por exemplo, é transportada para fábricas de papel na China, que, posteriormente, vendem sua produção para empresas européias que comercializam, principalmente, produtos de higiene pessoal.

O aprofundamento da divisão do trabalho impõe formas novas e mais elaboradas de cooperação e de controle, à escala do mundo, onde é central o papel dos sistemas de engenharia concebidos para assegurar uma maior fluidez dos fatores hegemônicos e uma maior regulação dos processos produtivos, por intermédio das finanças e da especulação. (Santos, 1996:203)

Os sistemas de engenharia aos quais Santos (1996) se refere são, especialmente, os fixos ligados à circulação do capital (seja em forma de mercadoria ou informação), que nunca foi tão fluida como nos dias atuais. $O$ processo produtivo está de tal forma pulverizado pelo planeta que é na circulação, usando o menor tempo possível, que a mais valia se realiza. Este novo funcionamento do sistema trouxe a diminuição dos circuitos produtivos regionais (de alcance espacialmente limitado) e possibilitou o surgimento dos circuitos espaciais da produção, de abrangência global.

O mundo encontra-se organizado em subespaços articulados dentro de uma lógica global. Não podemos mais falar de circuitos regionais de produção. Com a crescente especialização regional, com os inúmeros fluxos de todos os tipos, intensidades e direções, temos que falar de circuitos espaciais da produção. Estes seriam as diversas etapas pelas quais passaria um produto, desde o começo do processo de produção até chegar ao consumo final. (Santos, 1994:49) 
Contudo, a seletividade espacial também é marca desse novo período que o sistema atravessa. O tempo necessário para cruzar distâncias pode ter diminuído de maneira inversamente proporcional aos diferentes modos de fazêlo, mas o acesso a esse privilégio é tão restrito quanto maior for a sua potencialidade técnica e seu alcance espacial. Existe, portanto, uma hierarquia quanto ao uso desses sistemas técnicos que possibilitam uma maior racionalidade no uso do espaço, do território, da região.

O uso seletivo do espaço se daria sobretudo através desse processo, uma vez que, nas condições atuais de circulação rápida do capital, isto é, pela necessidade de rápida transformação do produto em mercadoria ou capital-dinheiro, isto é, nas condições atuais de reprodução, a capacidade maior ou menor de fazer circular rapidamente o produto é condição, para cada firma, de sua capacidade maior ou menor de realização ou, em outras palavras, do seu poder de mercado, o que também quer dizer poder político. (Santos, 1997:62)

Logo, o comando do funcionamento desse meio técnico, há muito, deixou as mãos dos Estados nacionais, e hoje está concentrado nas mãos das empresas, sobretudo as grandes firmas. Estas detêm a primazia sobre o uso dos sistemas técnicos, especialmente no que diz respeito ao comando dos circuitos espaciais, assim como das especializações produtivas nos territórios, regiões e lugares.

\section{3) GRANDES EMPRESAS E A ESPECIALIZAÇÃO NOS LUGARES}

Esta pesquisa identificou a existência de uma especialização produtiva no território nacional, que se estende como uma mancha de meio técnicocientífico-informacional, entre os estados do Espírito Santo e da Bahia, dinamizada pelas quatro grandes empresas do circuito produtivo de celulose que atuam nesta porção do território (Aracruz Celulose, Cenibra, BahiaSul Suzano e Veracel Celulose), como se pode observar no mapa a seguir. 


\section{Mapa 1 - Especialização produtiva de celulose}

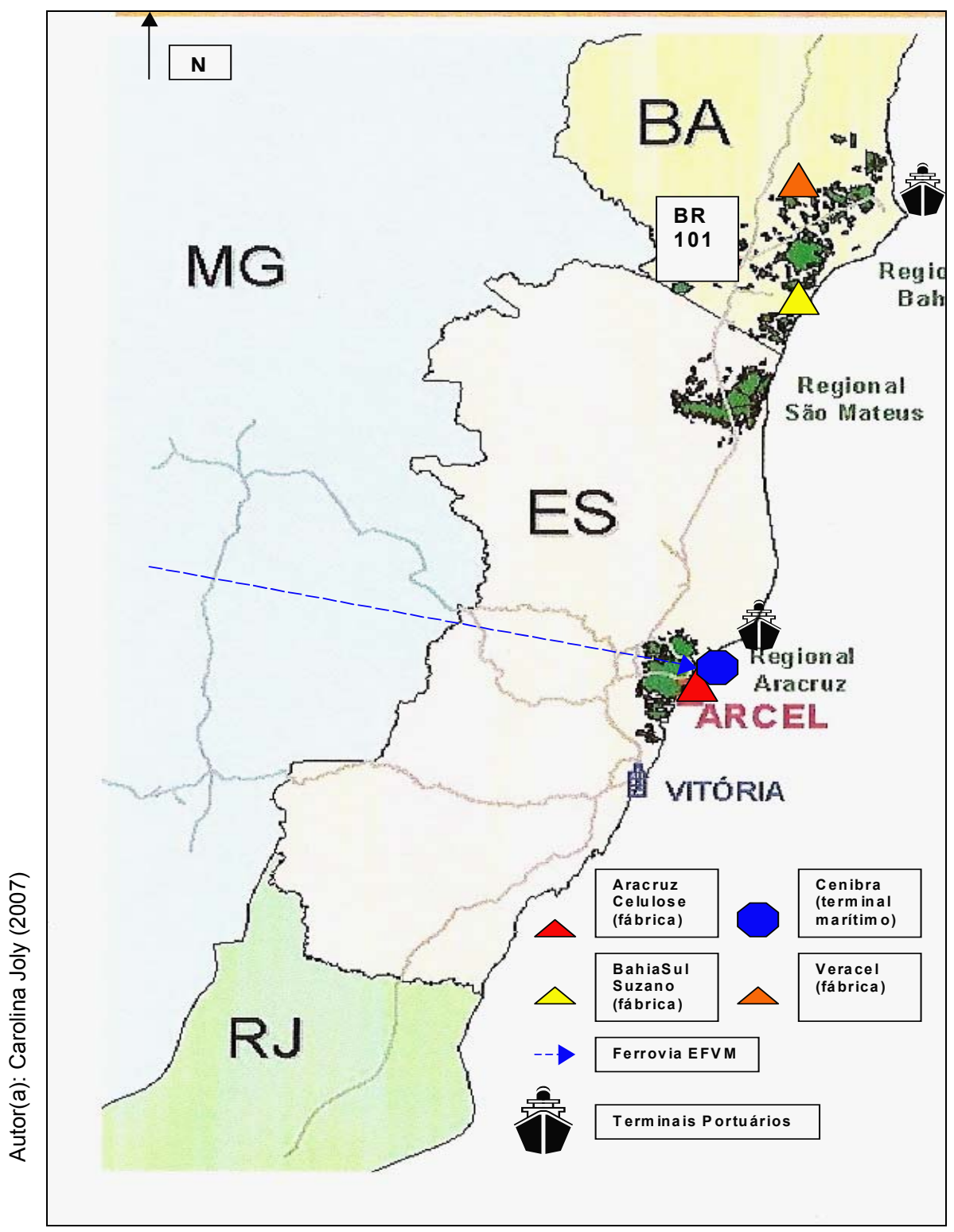

Porém, é na escala do lugar que se torna possível observar, com maior nitidez, os desdobramentos desse uso que as empresas fazem do território. A região ou o lugar são capazes de nos revelar o grau de inserção de um território na economia global, assim como a qualidade dessa inserção, através dos novos tipos de relações que se estabelecem, especialmente com o poder público e com a sociedade locais.

Compreender uma região [ou um lugar] passa pelo entendimento do funcionamento da economia ao nível mundial e seu rebatimento no território de um país, com a intermediação do Estado, das demais instituições e do conjunto de agentes da economia, a começar pelos seus atores hegemônicos. (Santos, 1994:46) 
A história do lugar também pesa, considerando tanto as condições preexistentes à chegada de novos objetos técnicos (como uma indústria, por exemplo) quanto a arquitetura das relações estabelecidas entre o novo e o velho. Por essa razão, o mesmo processo de inserção das localidades na economia mundial tem resultados diferentes, de acordo com as particularidades de cada lugar.

Na medida em que as possibilidades dos lugares são hoje mais facilmente conhecidas à escala do mundo, sua escolha para o exercício dessa ou daquela atividade torna-se mais precisa. Disso, aliás, depende o sucesso dos empresários. É desse modo que os lugares se tornam competitivos. O dogma da competitividade não se impõe apenas à economia, mas, também, à geografia. (Santos, 1996:199)

O município de Eunápolis, por exemplo, ou a localidade onde foi instalada a fábrica da Veracel, foram alvo de escolhas bem mais cuidadosas, por parte da empresa, do que o discurso globalizante da homogeneidade dos lugares nos deseja convencer. Dentre os fatores que podem ter contribuído para essa decisão, estão, por exemplo, a posição de centralidade que Eunápolis ocupa na hierarquia regional, concentrando atividades relevantes também para as empresas prestadoras de serviço para a Veracel, além do comércio, pois é um entreposto importante ao longo da rodovia BR-101.

Segundo a tipologia desenvolvida pelo Instituto Brasileiro de Geografia e Estatística (IBGE) em 2002, Eunápolis não alcançou a categoria de 'cidade média', pois oferece apenas bens (como produtos agropecuários, eletrodomésticos em geral) e serviços (hospital geral, serviços de contabilidade e advocacia, agências bancárias) considerados de baixa complexidade. Contudo, Eunápolis foi classificado como 'centro urbano regional', pois atende aos critérios populacionais (reunindo cerca de noventa mil habitantes), abriga sedes regionais de órgãos públicos estaduais, concentra fluxos regionais locais (possui linhas de ônibus regulares para as cidades próximas e para regiões metropolitanas) e está distante de metrópoles regionais (Itabuna, a mais próxima, está situada a duzentos e cinqüenta quilômetros de Eunápolis).

Outro fator a ser considerado na escolha de Eunápolis foi o forte apoio político dado ao empreendimento, sobretudo das esferas federal e estadual, onde a primeira conferiu crédito, e a segunda ofereceu todo um ajuste logístico 
ao empreendimento, fazendo concessões e asfaltando caminhos para a redução dos custos da empresa.

Certamente a organização do espaço pode ser definida como o resultado do equilíbrio entre os fatores de dispersão e de concentração em um momento dado na história do espaço. No presente período, os fatores de concentração são, essencialmente, o tamanho das empresas, a indivisibilidade das inversões e as 'economias' e externalidades urbanas e de aglomeração necessárias para implantá-las. Tudo isto contribui para a concentração, em uns poucos pontos privilegiados do espaço, das condições para a realização de atividades mais importantes. (Santos, 1997:29)

As modernizações trazem, sempre, modificações significativas para a estrutura sócio-espacial dos lugares, como aconteceu em Eunápolis. Porém, algumas transformações acabam por criar ou aprofundar antigos problemas. Na região de Eunápolis, por exemplo, o preço da terra sofreu um forte processo inflacionário. Desde que a Veracel começou a comprar propriedades na região, em 1996, a valorização do hectare chega a 267\%. Antes de 2004 (ano em que a fábrica começou a ser construída) o hectare custava, em média, $R \$ 1.200,00$, e hoje custa $\mathrm{R} \$ 4.400,00^{2}$. Outra forma de pressão sobre o campo, sentida especialmente pelas pequenas propriedades (impedidas de aderirem ao programa de fomento florestal da empresa, devido às suas dimensões), foi o seu isolamento. Essas propriedades ficaram "ilhadas", rodeadas por imensas plantações de eucalipto, que recobriram até mesmo antigos caminhos de acesso às estradas, dificultando o escoamento da produção dessas propriedades e até mesmo da locomoção das pessoas que ali vivem. As famílias acabam abandonando ou vendendo essas terras, que são anexadas às propriedades maiores e então podem abrigar as plantações de eucalipto. Esses dois fatores acabam funcionando como mecanismos de expansão da monocultura na região, além de fortalecer o movimento de êxodo rural, que já vem ocorrendo.

Entretanto, não podemos afirmar que a empresa é a única responsável por essas mazelas, pois ela obedece às normas que impedem o plantio em propriedades com área inferior ao permitido, além de respeitar todas as normas ambientais de plantio. A rigor, a Veracel cumpre todas as exigências sócioambientais que uma empresa, sobretudo financiada pelo Banco Nacional de

\footnotetext{
${ }^{2}$ Dados publicados no jornal folha de São Paulo, 30/04/06.
} 
Desenvolvimento Econômico e Social (BNDES), é obrigada a obedecer, inclusive mantendo ações de responsabilidade social e ambiental.

$\mathrm{Na}$ realidade, qualquer grande empreendimento, mesmo nos países desenvolvidos, traz consigo transformações nem sempre positivas para o lugar onde se instala. Porém, quando os lugares (como nas formações socioespaciais latino-americanas), já abrigam de antemão os problemas inerentes à desigualdade socioespacial (miséria, êxodo rural, desemprego, concentração fundiária, degradação ambiental), a desestruturação é muito mais profunda, deixando mais latentes as contradições impostas pela maneira como a sociedade atual se organiza e distribui poderes e riquezas.

Pontes (2006), ao analisar as mais recentes inversões em cidades médias nordestinas, como a fruticultura irrigada, a exploração de petróleo e a criação de pólos tecnológicos, concluiu:

Observamos, que de uma maneira geral, verificou-se no curso dos últimos anos, uma tendência à migração campo/cidade em virtude da estagnação de atividades primárias em várias áreas nordestinas. Entretanto, esta migração não tendeu a se fixar nas cidades pequenas, mas, encaminhou-se às cidades médias da região, na tentativa de buscar melhores condições de vida. Porém, tais cidades não tiveram condições de absorver este expressivo contingente populacional em face da sua estrutura produtiva, bem como não dispunham, de uma adequada infra-estrutura urbana que pudesse prodigalizar uma melhor qualidade de vida aos migrantes, acarretando, em virtude de tais problemas, a expansão de periferias urbanas empobrecidas, nas quais a população vive em bairros degradados, com acesso limitado aos serviços de saúde.

Embora, inquestionavelmente, vários centros tivessem conhecido expressivas mudanças e modernizações na sua estrutura produtiva, reconhecendo-se, inclusive, significativos avanços tecnológicos, estes, contudo, não foram capazes de proporcionar melhores condições sociais à população nordestina. $\mathrm{Na}$ verdade, foram grupos hegemônicos que se beneficiaram com as aludidas transformações. (Pontes, 2006:344)

Parte da responsabilidade cabe ao poder público, em todas as suas esferas, que se esforça para planejar e disponibilizar o uso do seu território para as grandes empresas, mas que simplesmente não leva em conta as dinâmicas e particularidades das regiões e lugares que preenchem esse mesmo território.

O discurso populista da geração de empregos e pagamento de impostos costuma seduzir os lugares eleitos para abrigar os empreendimentos bilionários. $E$ as empresas, por sua vez, investem nas doações (perfeitamente 
legais) às campanhas eleitorais locais, como fez a Veracel, no pleito de $2004^{3}$, enredando a psicoesfera dos lugares na ideologia do desenvolvimento local, que, no final, chega para muito poucos.

Em última instância, essa situação, somada à atual crise federativa em que o Brasil vive hoje, leva à prática da guerra fiscal ou guerra dos lugares, como chama Santos (1996), onde todos os atores envolvidos (sociedade e Estado), com exceção das grandes empresas, saem perdendo.

Contudo, é preciso que os lugares percebam que, ao abrigar um grande investimento privado e de ter seu espaço todo reorganizado para melhor servir às demandas das empresas, estes passam a ter uma expressiva vantagem de negociação com as empresas. Afinal, elas estão bem instaladas e deverão permanecer ali por algum tempo, pois dificilmente outro lugar seria tão adequado quanto aquele que já foi adaptado, ao contrário do que prega o discurso globalizante. No caso da Veracel, por exemplo, que possui cerca de cem mil hectares de eucaliptos plantados na região de Eunápolis, fez um investimento de US\$1,25 bilhões e obteve toda uma infra-estrutura logística apropriada para suas atividades, parece pouco provável que deixe a região tão cedo.

O poder de barganha dos lugares, conferido então pelo próprio fato de abrigarem esses investimentos, permite a negociação de contrapartidas, por parte do poder público local, junto às empresas. O governo baiano poderia, por exemplo, incentivar, através de crédito rural, a prática de uso misto do solo nas áreas de plantio de eucalipto. Ao conciliar a área ocupada pela monocultura com outros produtos, como feijão, café ou gado, a produção regional se diversifica e mais mão-de-obra é fixada no campo. Experiências semelhantes têm sido feitas nos plantios de eucalipto fomentados pelo governo capixaba, no norte do Espírito Santo, com resultados positivos.

\footnotetext{
${ }^{3}$ Nas eleições municipais de 2004 , a Veracel doou $R \$ 560.000,00$ para as campanhas de todos os candidatos à prefeitura dos dez municípios baianos onde a empresa possui áreas de plantio. Fonte: ONG Transparência Brasil.
} 
Capítulo 2

\section{O circuito espacial produtivo de celulose no território brasileiro e a especialização produtiva no norte do Espírito Santo}

Outra vez ouço o trem ao me aproximar de Carpina.

Vai passar na cidade, vai pela chã, lá por cima.

Detém-se raramente, pois que sempre está fugindo, esquivando apressado as coisas de seu caminho.

Diversa da dos trens é a viagem que fazem os rios: convivem com as coisas entre as quais vão fluindo; demoram nos remansos para descansar e dormir; convivem com a gente sem se apressar em fugir.

(Trecho do poema O rio, de João Cabral de Melo Neto) 


\section{1) ORIGEM E CONSOLIDAÇÃO DO CIRCUITO NO PAÍS}

A produção de celulose (ao contrário daquela de papel, que tem participação restrita) ocupa atualmente uma posição de destaque na pauta de exportação brasileira, ficando, nos últimos anos, sempre entre os dez produtos mais vendidos pelo país. O Brasil exporta hoje cerca de $52 \%$ da sua produção nacional. ${ }^{4} \mathrm{O}$ circuito está bastante aquecido na América do Sul, com previsão de muitos investimentos representativos, por conta da boa valorização que o preço da celulose tem conquistado no mercado nos últimos anos.

O empreendimento que ganhou maior notoriedade nos principais meios de comunicação recentemente foi aquele gerador da atual disputa política, travada entre os governos argentino e uruguaio, à respeito da implantação de uma fábrica de celulose às margens do Rio Uruguai, que separa os dois países. As multinacionais Botnia (finlandesa) e Ence (espanhola), donas do empreendimento e apoiadas pelo governo uruguaio, tentam a todo custo, iniciar as operações produtivas da fábrica, mas o impasse instaurado por medidas do governo argentino (que alega preocupar-se com questões ambientais envolvidas, sofrendo forte pressão popular contra a instalação) não permitem visualizar uma solução a curto prazo.

Cabe frisar aqui que, para os teóricos que acreditavam no fim das fronteiras nacionais como principal legado da globalização, o exemplo desta disputa, a qual, segundo Alvarado (2006), também ameaça tratados que respaldam o próprio Mercosul, mostra que as fronteiras continuam com a mesma importância geopolítica e até, econômica que sempre tiveram. Para Alvarado (2006),

Durante o último ano, o sul do continente se viu comovido por um intenso e imprevisível conflito entre Uruguai e Argentina, de base claramente territorial. Este conflito, originalmente causado por inquietudes relacionadas com a preservação ambiental na escala local, tornou-se rapidamente em um conflito diplomático de escala internacional, que sobrepôs o ambiental para por em jogo interesses políticos, geopolíticos, econômicos, despertar sentimentos nacionalistas e, inclusive, por em dúvida - por parte do Uruguai - o processo de integração regional.(Alvarado, 2006:1) ${ }^{5}$

No Brasil, a sueco-finlandesa Stora Enso (parceira da empresa Aracruz Celulose na joint venture Veracel) tem interesse na compra de terras para

\footnotetext{
${ }^{4}$ Fonte: Ministério do Meio Ambiente (Fanzeres, 2005).

${ }^{5}$ Tradução nossa.
} 
plantio de eucalipto na região da fronteira entre Brasil e Uruguai ${ }^{6}$. Ao que consta, a empresa já é dona de trinta mil hectares no centro-norte do Uruguai, com o objetivo de chegar rapidamente a cem mil hectares, e de construir, daqui a seis anos, (tempo que o eucalipto leva para chegar à idade de corte) uma nova fábrica de celulose na região.

Segundo o diretor da divisão para a América Latina do grupo Stora Enso, Nils Grafström, a tendência da empresa e do setor é de fechar as fábricas mais custosas do Hemisfério Norte, principalmente nos EUA e no Canadá, e abrir outras no Hemisfério Sul, sobretudo devido ao baixo custo de produção da madeira, inferior a $50 \%$ do custo médio nos países do Norte.

Como as árvores crescem muito rápido, são necessários menos terrenos e podemos estar mais perto da usina, o que reduz ainda mais os custos. O Brasil e o Uruguai são preferidos a outros países da região como o Chile, onde a maioria das terras já estão sendo aproveitadas, e a Argentina, onde as incertezas jurídicas e políticas são maiores. ${ }^{7}$

A Aracruz Celulose, por sua vez, também tem planos de construir, em breve, uma nova fábrica no estado do Rio Grande do Sul, ao lado daquela já instalada no município de Guaíba-RS. A despeito dos ataques de movimentos sociais sofridos pela empresa em março de 2006, ela já começou a ampliar de vinte mil para cem mil hectares o plantio de eucaliptos na região, para que a fábrica entre em operação entre os anos de 2010 e $2015^{8}$.

No extremo sul da Bahia, região onde foram concentradas as investigações desta pesquisa, a Bahia Sul Suzano está, neste momento, duplicando a sua fábrica, instalada no município de Mucuri-BA, próximo à Teixeira de Freitas-BA, com previsão para início de operação no primeiro semestre de 2007. E a Veracel, por sua vez, também deverá ser duplicada em breve, para começar a operar no ano $2010^{9}$.

Estes são apenas alguns exemplos dos futuros investimentos do circuito no território brasileiro, pois há outros menos evidentes sobre os quais ainda há muita especulação. Mas o fato é que o Brasil alcançou um patamar de

\footnotetext{
${ }^{6}$ Informação coletada em entrevista com Eng ${ }^{\circ}$ Figueiredo, executivo da Aracruz Celulose, realizada em 08/06/06.

${ }^{7}$ Entrevista concedida pelo diretor da divisão para a América Latina da Stora Enso, Nils Grafström, à agência de notícias France Presse, publicada no caderno de economia do jornal Correio Popular, de Campinas, em 04/06/06.

${ }^{8}$ Informação publicada no caderno Dinheiro do jornal Folha de São Paulo, em 30/06/06.

${ }^{9}$ Informações publicadas no caderno Dinheiro do jornal Folha de São Paulo, em 12/07/06.
} 
excelência em produção de celulose branqueada de eucalipto, sendo mundialmente reconhecido e nacionalmente muito apoiado pelas políticas industriais das últimas décadas.

Esse bom desempenho atual do circuito no país, no entanto, vem sendo construído há pelo menos um século, e se deve, em linhas gerais, a dois grandes fatores: o primeiro foi a insistência dos pioneiros do setor, que criaram suas empresas, entre o final do século $X I X$ e início do século $X X$, sem qualquer tipo de apoio do Estado; e o segundo fator, ocorrido a partir dos anos 30, mas sobretudo depois da década de 60 , foi o intenso apoio do poder público dado ao circuito, com políticas industriais extremamente direcionadas.

Quanto ao primeiro período mencionado, é preciso lembrar da importância do capital financeiro acumulado pela economia cafeeira, que trazia divisas para os investidores paulistanos, permitindo a construção de estradas de ferro, abertura de bancos, comércios diversos e também indústrias. Como afirma Cano (1998):

Dessa forma, o capital cafeeiro ampliou cada vez mais as bases da acumulação em São Paulo, proporcionando amplo leque de alternativas de inversão para os lucros que podiam vazar da cafeicultura e dos negócios vinculados ao café. Por outro lado, assalariando sua mão-de-obra, criou amplo mercado de bens de consumo para a indústria, que então dava seus primeiros passos. Além disso, ao constituir seu mercado de trabalho com oferta abundante de trabalho, possibilitou também a criação de um mercado de trabalho urbano do qual se serviu principalmente a indústria paulista.

Dessa forma, a partir da década de 1880 inicia-se o capitalismo no país, criando as bases regionais mais sólidas para os primeiros momentos de nossa formação industrial. (Cano, 1998:284)

Contudo, segundo Mamigonian (1976), os "barões do café" se mostraram inaptos a comandar a passagem da economia agrária/exportadora de produtos tropicais para a economia capitalista de base industrial, apesar de terem criado as primeiras manufaturas de São Paulo. Para o autor, além de não possuírem o espírito de livre iniciativa, justamente por enxergarem a indústria como extensão dos negócios da fazenda, esta classe social não consumia seus próprios produtos, pois preferia os artigos importados da Europa.

Já a tentativa da aristocracia paulista de superar seu próprio sistema colonial/latifundiário, tornando-se burguesia industrial, muito mais difícil do que construir estradas de ferro para escoar café, mostro-se simplesmente desastrosa. (Mamigonian, 1976:86) 
Os fazendeiros, via de regra, acabaram perdendo seus negócios industriais para pequenos comerciantes estrangeiros, imigrantes que chegaram à São Paulo nesse período, embuídos do espírito capitalista europeu. Muitos pioneiros, a quem nos referimos, foram, justamente, alguns desses imigrantes, que, à procura de oportunidade no Brasil, acabaram fundando algumas das maiores empresas do circuito de papel e celulose do país até hoje, como a Klabin, a Melhoramentos e a Suzano. Eram empreendedores de visão que começaram seus impérios com pequenos negócios, sem poder contar com apoio de políticas públicas de incentivo, que, até então, se voltavam para o café.

Ainda no final do século XIX, já havia produção industrial de papel nas regiões Sul e Sudeste do país, mas ainda de forma incipiente, utilizando matérias-primas inadequadas, porém, abundantes, que atingia uma demanda interna por papéis menos nobres, utilizados em embalagens. $O$ restante tinha que ser importado.

Nas duas primeiras décadas do século $X X$, entretanto, a demanda por papel começava a aumentar nas cidades do país (especialmente no Rio de Janeiro, em São Paulo e nos núcleos urbanos que as ferrovias desenvolveram até esse período), devido à consolidação do meio de vida urbano e do crescente mercado consumidor, iniciado com o fim da mão-de-obra escrava. Nesse período, é criada no município de Caieiras-SP, a Companhia Melhoramentos de São Paulo (1900). Contudo, estava praticamente falida quando, em 1920, foi comprada pelos irmãos Weiszflog, imigrantes alemães, donos de uma pequena tipografia na capital paulista. Nessa mesma época, o imigrante russo Leon Feffer fundou sua primeira manufatura de papel, em 1923, no bairro paulistano do Brás. Seus negócios foram crescendo até que, em 1940, inaugurou a sua fábrica de papel Companhia Suzano de papel e celulose, na cidade de Suzano-SP. Também nesse período destacam-se os irmãos Klabin e Lafer, imigrantes lituanos, que em 1909, fundaram a Klabin Irmãos e Companhia, no bairro de Santana, em São Paulo e que, atualmente é a maior empresa de papel e celulose da América do Sul.

Segundo Marcovitch (2005), foram 
pioneiros e empreendedores que se tornaram referências na introdução de produtos ou serviços até então inexistentes em nosso parque empresarial e que contribuíram, de forma tangível, para o desenvolvimento da região Centro-Sul. (Marcovitch, 2005:24)

Até a década de 20 , essa produção pioneira contínua com força, mas sempre muito dependente da importação de maquinário, de celulose escandinava para misturar ao produto nacional e de papel de imprensa. Além disso, as primeiras indústrias de papel e celulose que surgiram eram todas integradas, ou seja, produziam (ou importavam da Escandinávia) a pasta de celulose para confeccionar seu papel. Somente mais tarde, em meados dos anos 40, essa lógica de produção é modificada, originando também os segmentos que produzem celulose somente para comercialização, sem transformá-la em papel (a chamada celulose de mercado).

No contexto desse período, cabe a pergunta:

Teria o Estado facilitado ou dificultado o crescimento industrial?

A principal preocupação do Estado não estava voltada para a indústria, mas para os interesses agroexportadores. Entretanto, não se pode dizer que o governo tenha adotado um comportamento atiindustrialista. Houve proteção governamental em certos períodos à importação de maquinaria, reduzindo-se as tarifas da alfândega. Em alguns casos, o Estado concedeu empréstimos e isenção de impostos para a instalação de indústrias de base. Por outro lado, a tendência de longo prazo das finanças brasileiras no sentido da queda da taxa de câmbio tinha efeitos contraditórios com relação à indústria. A desvalorização da moeda encarecia a importação dos bens de consumo e, portanto, estimulava a indústria nacional, mas, ao mesmo tempo, tornava mais cara a importação de máquinas de que o parque industrial dependia.

Resumindo, se o Estado não foi um adversário da indústria, esteve longe de promover uma política deliberada de desenvolvimento industrial. (Fausto, 2000:289)

O marco decisivo de mudança se deu com o início do governo de Getúlio Vargas, em 1930, quando o circuito passa a receber forte apoio estatal. Vargas tinha como objetivo tornar o país auto-suficiente na produção de papel e derivados, através da política de substituição de importações, dada a profunda crise de 1929 que derrubou a economia cafeeira. Dentre as medidas de incentivo, estão a isenção de impostos para a importação de máquinas, insumos, ferramentas, etc., além de auxílio financeiro na construção de unidades fabris, no fornecimento de energia elétrica e nas instalações dos laboratórios de pesquisa. Em contrapartida, o governo exigia a produção mínima de cinco toneladas diárias de papel, além da condicionante de somente utilizar matéria-prima nacional. 
Através desses incentivos, os irmãos Klabin criaram, em 1940, a primeira fábrica de celulose do país, no município de Telêmaco Borba-PR. Até este período, a produção de papel e celulose no Brasil passou por diversas etapas, onde a chave das mudanças foi sempre a inovação da técnica de produção (processos, maquinário, matéria-prima). Associado a este fato, também ocorria um crescente acúmulo de objetos técnicos à configuração territorial das regiões Sul e Sudeste do país, onde estavam concentradas as fábricas de papel e celulose da época. Além de constituírem o "motor" econômico do país, essas regiões também concentravam as reservas florestais (como as matas de araucárias), além dos recursos hídricos abundantes (facilitando a instalação de hidrelétricas) e as redes de ferrovias e rodovias já consolidadas ou em franca expansão. Nesse período, também já existia em São Paulo, o Serviço Florestal (antigo Horto Botânico de São Paulo e futuro Instituto Florestal), que iniciava algumas pesquisas florestais associadas às principais empresas da época. Mas a participação do poder público, arcando com as responsabilidades normativas de incentivo, também foi crucial para a consolidação do setor. Horácio Lafer (um dos fundadores da empresa Klabin), por exemplo, chegou chefiar o Ministério da Fazenda do Governo de Getúlio Vargas.

Em 1957, durante o governo de Juscelino Kubitschek, é lançado o Plano de Metas (1957-1960), no qual as indústrias de papel e celulose sofrem grande expansão da capacidade produtiva, através da combinação entre financiamentos do então Banco Nacional de Desenvolvimento Econômico (BNDE) e também da abertura ao capital externo. As principais empresas do setor (herdeiras do pioneirismo e algumas filiais estrangeiras) se reafirmam no mercado e se tornam grandes empresas. Assim, começa o processo de oligopolização do circuito, percebido até hoje.

Com o início do período militar, em 1964, começa uma verdadeira preparação do território, tanto no aspecto normativo quanto na configuração territorial do país, para dar o grande salto do circuito produtivo, especialmente no segmento de celulose. $O$ objetivo era tornar uma produção que ainda não era capaz de suprir o mercado interno plenamente numa produção com volume e qualidade para exportação de celulose. 
Em 1965, é criado o novo Código Florestal, que contribui para o início das atividades de reflorestamento programado, portanto, para a formação de fontes renováveis de suprimentos de madeira. Em 1966, institui-se o plano de Incentivos Fiscais ao Reflorestamento, que beneficiou sobremaneira o circuito de celulose, pois previa uma série de abatimentos tributários significativos para que as propriedades fossem reflorestadas, aumentando bastante a oferta de madeira para ser explorada. Em 1967, é criado o Instituto Brasileiro de Desenvolvimento Florestal (IBDF), em substituição ao Instituto Nacional do Pinho, a fim de coordenar as políticas florestais no país. Nesse mesmo ano, forma-se a primeira turma de engenheiros florestais de um convênio entre o IBDF e a FAO/ONU. Em 1968, o governo criou o Instituto de Pesquisas Florestais (IPEF), numa iniciativa conjunta da Escola Superior de Agricultura Luiz de Queiroz (ESALQ) da Universidade de São Paulo e das empresas Champion, Duratex, Rigesa, Suzano e Madeirit. Esse instituto teve um papel importante na difusão das técnicas de manejo e seleção das espécies mais aptas para a produção (onde o eucalipto era uma boa promessa).

A descoberta do eucalipto como matéria-prima para a fibra curta merece um capítulo à parte, mas faremos aqui um breve resumo de sua história, que também ajudou o Brasil a conquistar a excelência em produção de celulose que hoje possui. As pesquisas tiveram início ainda nos anos 50, através da empresa Suzano, que pesquisava novas fontes alternativas de fibra para celulose. A empresa chegou a alugar um laboratório de pesquisa na Universidade da Flórida, nos EUA, para descobrir e confirmar as potencialidades do eucalipto. Com a difusão desses conhecimentos agronômicos para outras empresas, através do IPEF e do Instituto Florestal de São Paulo (IF), o eucalipto se tornou uma unanimidade nacional.

Todos esses incentivos representaram, na prática, um franco reforço na criação de barreiras institucionais à entrada de novas empresas no circuito (oligopolização), e, ao mesmo tempo, consolidou as empresas líderes (mais promissoras) para receberem os recursos do BNDES com vistas à exportação.

Segundo afirma Dalcomuni (1990):

Durante a gestão Geisel, e atendendo a reivindicações do setor, o governo instituiu os "distritos florestais", que tinham como função estabelecer um zoneamento florestal de forma a nortear a concessão desses incentivos. Esses distritos florestais abrangiam áreas dos 
estados do Rio Grande do Sul, Paraná, São Paulo, Minas Gerais, Rio de Janeiro, Espírito Santo, Bahia e Pará. Além disso, o governo instituiu o FISET (Fundo de Investimentos Setoriais - pesca, turismo e reflorestamento). Constitui-se, também, neste período uma Comissão de Política Florestal composta por membros de vários ministérios, representantes do setor, do Estado Maior, das Forças Armadas, sendo presidida pelo IBDF. Em complementação a essas medidas institucionais, a canalização de vultosos financiamentos via BNDES e de estatais e a concessão de incentivos e subsídios à exportação conferiram ao Estado brasileiro um papel fundamental na evolução da indústria de celulose no Brasil. (Dalcomuni, 1990:85)

Na década de 70, os impulsos para que o circuito atingisse finalmente 0 mercado externo foram intensos, através do II Plano Nacional de Desenvolvimento (PND), lançado em 1974, dentro do qual foi criado o I Programa Nacional de Papel e Celulose. O governo atraiu fortemente o capital estrangeiro prevendo a formação de "joint-ventures" para o setor, combinando capitais privados nacionais, estatais e externos.

Dentre os fatores que funcionaram como atrativos para o capital externo estão a forte pressão, nessa época, que os movimentos ambientalistas dos países desenvolvidos estavam fazendo sobre suas indústrias poluidoras, dentre as quais as de celulose. Além disso, a FAO/ONU divulgou, neste período, um documento afirmando que a produção mundial de papel e celulose logo seria superada pelo crescente aumento da demanda mundial, fazendo com que o planeta enfrentasse, em breve, um período de escassez de papel. Outro fator de atração se deve ao crescimento impressionantemente rápido do eucalipto, logo, dos maciços florestais, no Brasil. Enquanto as reservas florestais da Escandinávia, do Canadá e dos EUA levam de oitenta a cem anos e algumas espécies entre vinte e cinco e trinta anos para atingirem a idade de corte, no Brasil esse período é de, em média, sete anos. Essa se tornou uma das maiores vantagens comparativas do país.

Desse modo, o circuito produtivo de celulose ganha porte para alcançar a exportação, atingida no final dos anos 70 , com base no padrão eucalipto (celulose de fibra curta branqueada). Internaliza-se no país uma estrutura de produção no setor nos moldes vigentes da indústria mundial, ou seja, com forte concentração de capitais, expressa pelo grande porte das escalas de produção, alto grau de integração vertical das empresas com produção própria de madeira e demais insumos, e integração da transformação industrial e comercialização da produção ${ }^{10}$. A Aracruz Celulose, por exemplo, constituída

\footnotetext{
${ }^{10}$ Dados fornecidos por Dalcomuni (1990).
} 
em 1972, inicia as operações da sua primeira unidade fabril de celulose, no Espírito Santo, em 1978, com uma produção de quatrocentas mil toneladas por ano, destinadas à exportação ${ }^{11}$.

Nos anos 80, o circuito produtivo de celulose constituiu uma exceção em meio à crise generalizada e continuou a crescer, mas houve uma diminuição dos investimentos em novas plantas.

Na década de 90, houve um forte processo de concentração de capital, através de aquisições e fusões, envolvendo também capital externo, pois a abertura comercial neste período foi bastante agressiva. No circuito produtivo de celulose, permaneceram somente as empresas de grande porte e as exportadoras. Elas investiram fortemente em processos de redução de custos, terceirizando boa parte dos serviços de manutenção e fornecimento de insumos. Modernizaram suas fábricas para aumentar a produção sem construir novas plantas. Investiram também na redução dos custos de transporte, armazenamento e embarque da celulose, através da modernização e privatização dos terminais portuários e ferrovias, garantindo assim, as vantagens operacionais. Além disso, apostaram na mecanização e automatização dos processos, desde o plantio e colheita da madeira até os centros de controle da produção. Algumas, como a Aracruz e a Veracel, possuem até contratos com empresas que monitoram remotamente suas áreas de florestas, com sistemas de sensoriamento remoto por satélites e de informação geográfica (SIG).

Nesse período, a pressão do discurso ambiental ganha mais força no país e as empresas passam a fazer investimentos também em sistemas de adequação às normas nacionais e internacionais de controle da poluição. $A$ rede de agências de certificação e auditoria ambiental cresce, pois o mercado comprador da celulose produzida aqui, ou seja, os países desenvolvidos, também começa a ser mais exigente com relação à origem da madeira e aos processos produtivos. Hoje, existe uma cobrança, até mesmo em termos de legislação, para que as empresas adotem práticas de responsabilidade socioambiental, nos lugares onde se instalaram.

\footnotetext{
${ }^{11}$ Dados fornecidos pelo material institucional da empresa, concedido em visita à fábrica, em 08/06/06.
} 
Em termos ambientais, o uso do cloro, por exemplo, utilizado para branquear a pasta de celulose, é abolido pelos órgãos fiscalizadores, por ser altamente poluidor. As empresas, então, tiveram que se ajustar rapidamente a essas normas, instalando filtros e alterando os processos produtivos. A produção de papel reciclado é uma das formas encontradas pelas empresas de agradar esses consumidores, além de ampliar os seus mercados.

Outra nova fronteira de mercado para essas empresas consiste no chamado mercado de carbono. Através de suas reservas florestais elas podem participar do comércio internacional de carbono (criado no contexto do Protocolo de Kyoto, ratificado em 1997), vendendo créditos nas bolsas de valores para os países poluidores do Hemisfério Norte. Apesar de ainda ser um tipo de comércio em desenvolvimento, as empresas já estão se preparando para aumentar suas áreas florestais com intenções de participar desse mercado promissor.

Nos últimos anos, com a estabilização da economia, o circuito volta a fazer investimentos em novas plantas produtivas e em áreas de floresta. $O$ preço internacional da celulose ganha fortes posições e atrai investidores estrangeiros, como a parceira da Veracel, a Stora Enso, para o país. Os processos de concentração de capital continuam, assim como as reduções de custos da produção. As fábricas empregam cada vez menos funcionários, pois a automatização é constante.

Atualmente, é possível perceber claramente que as empresas líderes da esfera internacional do circuito, que em seus países de origem produziam celulose e papel, estão investindo pesadamente na transferência de suas unidades de produção de celulose para o Cone Sul. As fábricas de papel, menos poluidoras e que elaboram um produto com maior valor agregado, permanecem no Hemisfério Norte. Ou seja, elas produzem sua própria matéria-prima, a custos baixíssimos, explorando todo tipo de vantagem locacional oferecido pelos países do Cone Sul (terras e mão-de-obra baratas, know how qualificado, incentivos estatais, menor rigor de normas ambientais e condições climáticas favoráveis), e com comprador garantido, que são as suas próprias unidades fabricantes de papel, localizadas no Hemisfério Norte. É um típico caso de comércio intra-empresa, que reproduz e aprofunda as desigualdades a nível global. 


\section{2) PolíticAs PÚBlicAs ATUAis PARA O CIRCUITO}

Na última década, houve um crescente aumento no consumo mundial de papel e derivados (como embalagens, por exemplo), devido ao aquecimento generalizado da economia internacional, e, em especial, do mercado consumidor chinês. As grandes empresas do circuito espacial produtivo de celulose fazem grandes investimentos em novas unidades produtivas na América do Sul, onde o tempo de desenvolvimento da matériaprima é muito mais rápido que no hemisfério norte, como já foi apontado. O Brasil e o Chile foram os principais parceiros nesses investimentos, que, mais recentemente, também chegaram ao Uruguai. Somando os mercados das principais empresas transnacionais hoje instaladas no Cone Sul, (Botnia, finlandesa, Ence, espanhola, Stora Enso, sueco-finlandesa e Lorentzen, norueguesa), o domínio chega a $80 \%$ do comércio internacional de celulose.

Porém, outros fatores, para além das boas condições climáticas, contribuíram para atrair esses investimentos. Desde a estabilização da economia e da atmosfera política, com o início do Governo Fernando Henrique Cardoso, em 1994, constitui-se um cenário interessante para essas empresas. O Estado brasileiro se colocou numa condição de mero regulador da economia, deixando que as empresas passassem a conduzir o planejamento do território nacional, ou, como ocorre muitas vezes, governando para elas. Isenções fiscais, tributárias, financiamentos, execução de obras de infraestrutura, privatizações, são alguns dos mecanismos de atração de investimentos dos quais o poder público lançou mão para beneficiar a iniciativa privada.

No entanto, havia no território, no final da década de 90, um obstáculo a ser enfrentado pelas empresas estrangeiras do circuito que decidiram investir no país, e mesmo para as empresas nacionais, que desejavam expandir sua produção. O chamado "apagão florestal" inviabilizava a operação imediata das fábricas, que só foram construídas ou ampliadas no início da década seguinte, como a Veracel. As áreas reflorestadas, destinadas a fabricação de celulose, na época, eram insuficientes para acompanhar a demanda crescente por madeira. As soluções encontradas pelas empresas foram a compra de terras 
para plantio imediato e a intensificação do programa de fomento florestal. Mas como as árvores levam até sete anos para atingirem a idade de corte, somente entre 2004 e 2005, quando as fábricas estavam ficando prontas, é que elas começaram a usar, de fato, essa madeira.

O governo federal, para contribuir com a reversão desse quadro de “apagão", lançou em 2003, o Programa Nacional de Florestas, coordenado pelo Ministério do Meio Ambiente, que previa a extensão do fomento florestal não mais vinculado às empresas, mas através do poder público. O Estado, por meio de concessão de crédito do Banco do Brasil, passou a oferecer linhas de crédito especiais para pequenos e médios produtores plantarem pinus e eucalipto.

O Plano Nacional de Florestas, enviado ao Congresso Nacional pelo governo federal prevê, simultaneamente, o incentivo ao plantio, à proteção das matas nativas e a incorporação de milhares de pequenos e médios produtores à atividade florestal lucrativa. A orientação que demos ao BNDES consiste em vincular novos financiamentos ao setor de papel e celulose a um compromisso empresarial com a expansão de pequenos e médios fornecedores de florestas plantadas. (Presidente da República, Luiz Inácio Lula da Silva) ${ }^{12}$

Antes do lançamento desse programa de incentivo, o Brasil plantava, anualmente, cerca de trezentos e vinte mil hectares de madeira, sendo que menos de $8 \%$ dessa área estava concentrada em pequenas e médias propriedades. Hoje, a média de plantio anual é de quinhentos e vinte mil hectares, com 19\% dos reflorestamentos feitos por pequenos e médios produtores. O governo espera, em 2007, chegar à meta de $30 \%$ dos plantios concentrados nessas pequenas e médias propriedades, revertendo definitivamente o "apagão" que predominou nos anos 90. Estima-se que haja, atualmente, cerca de três milhões de hectares cobertos por reflorestamento de eucalipto no país ${ }^{13}$.

No sul da Bahia, por exemplo, desde 2003, o Banco do Nordeste oferece financiamento para atividades de reflorestamento através do Programa Nacional de Agricultura Familiar (PRONAF) Florestal, numa parceria entre o Ministério do Desenvolvimento Agrário, o Ministério do Meio Ambiente e o Governo da Bahia. O financiamento também cobre a elaboração do projeto, o licenciamento ambiental e a assistência técnica, feitos pela Secretaria Estadual

\footnotetext{
${ }^{12}$ Pronunciamento proferido em 28/09/05, em Eunápolis-BA, por ocasião da inauguração da fábrica da Veracel.

${ }^{13}$ Fonte: Ministério do Meio Ambiente.
} 
do Meio Ambiente e Recursos Hídricos da Bahia. O mesmo pacote é também oferecido pelo governo do Espírito Santo, que compra as mudas, por preços especiais, dos viveiros da Aracruz e os repassa aos agricultores.

O Banco do Brasil também oferece linhas de crédito especiais para as atividades de silvicultura em todo território nacional, lançando, em 2005, o Programa BB Florestal, que hoje engloba o PRONAF Florestal. Esse programa é destinado aos mini e pequenos produtores da agricultura familiar e da agricultura empresarial. Sua meta é financiar R $\$ 225$ milhões em cinco anos (R\$ 45 milhões/ano), o que corresponde ao plantio de cerca de cento e cinqüenta mil hectares até 2009 . No seu primeiro ano, a meta de desembolso foi superada em $300 \%$, pois foram liberados $R \$ 135,4$ milhões entre os meses de Janeiro e Dezembro de 2005, correspondentes a 4.891 operações em quatorze estados, com destaque para São Paulo (R\$ 66,6 milhões) e Rio Grande do Sul (R\$36,2 milhões) ${ }^{14}$.

A principal diferença entre os agricultores que adotam esses programas do governo e aqueles que se tornaram fomentados das empresas é que, os primeiros não são obrigados a vender sua produção para as empresas, enquanto os fomentados, por contrato, devem destinar a produção do primeiro e, às vezes, até do segundo corte, para a empresa que o contratou. A madeira financiada pelo Programa BB Florestal pode ser destinada, além da fabricação de celulose, a setores como os de movelaria, carvão vegetal e caixetaria (embalagens, pallets), por exemplo, que também utilizam esses recursos. No Espírito Santo, o governo estadual tem incentivado os agricultores sem contrato de fomento a plantar outras culturas que podem se desenvolver junto com o eucalipto, na sua fase arbustiva, proporcionando a diversificação produtiva desses agricultores, através do uso misto do solo.

Da mesma forma que o governo oferece crédito aos produtores, também o oferece às empresas do circuito de celulose, através dos financiamentos do BNDES, principalmente. No ano de 2005, por exemplo, o circuito recebeu o quinto maior volume de recursos do banco, além de ter recebido o maior volume de recursos para o setor dos últimos dez anos, cerca de $\mathrm{R} \$ 1.415,1$ milhões. ${ }^{15} \mathrm{O}$ mote é sempre a geração de empregos e de

\footnotetext{
${ }^{14}$ Fonte: Ministério do Meio Ambiente.

${ }^{15}$ Fonte: BNDES, Ministério do Desenvolvimento, Indústria e Comércio Exterior.
} 
impostos para a União, como único caminho para o crescimento econômico, no entanto, essas empresas automatizam e terceirizam cada vez mais sua produção. E como quase todas elas são exportadoras, estão isentas de pagamento do Imposto sobre Circulação de Mercadorias e Serviços (ICMS), uma das principais fontes de receita dos governos estaduais, graças à Lei Kandir (lei complementar $n^{\circ} 87 / 96$ ), em vigor desde 1996. Além disso, desde 2002, essa lei sofreu alterações que obrigam o governo federal a compensar financeiramente os estados que perderam arrecadação por causa desse mecanismo de isenção. Ou seja, os cofres públicos pagam duas vezes para abrigar esses investimentos do setor.

O Estado também se preocupa em oferecer condições competitivas na infra-estrutura de circulação do território para esses grandes projetos do circuito espacial produtivo de celulose. Projetos como a modernização dos portos, aeroportos e a privatização de rodovias e ferrovias vêm atender a essa demanda de fluidez territorial dessas empresas. O exemplo da nova unidade produtiva da Aracruz, que será instalada no Rio Grande do Sul entre 2010 e 2015, é bem ilustrativo:

A Aracruz ainda espera do governo, porém, que faça a adequação da infra-estrutura rodoviária para melhorar o fluxo nas estradas, a criação de condições para uso das hidrovias no transporte de madeira e celulose, suporte tributário para viabilizar processos da indústria e a realização de melhorias no abastecimento de energia elétrica para os moradores de Guaíba e Barra do Ribeiro. ${ }^{16}$

O novo empreendimento do Grupo Orsa, no sul do país, também é exemplar:

Rio Grande do Sul e Santa Catarina vão disputar um investimento de $R \$ 160$ milhões do Grupo Orsa, de São Paulo. O projeto consiste na construção de duas fábricas. A previsão é de que a primeira unidade tenha capacidade de produção anual de 100 mil toneladas de embalagens de papelão ondulado, empregado principalmente para o transporte de cargas de alimentos e fumo. A segunda unidade será viabilizada apenas a partir da conclusão da primeira e está orçada em aproximadamente $\mathrm{R} \$ 90$ milhões. Deve produzir papel reciclado para abastecer a primeira fábrica. Atualmente, o grupo vende a partir de São Paulo 50 mil toneladas por ano de papelão ondulado para os dois estados. As negociações com o Rio Grande do Sul foram iniciadas na última sexta-feira, após uma audiência com representantes do grupo (entre eles o presidente da Orsa Celulose, Papel e Embalagens, Jorge Henriques) e o governador Germano Rigotto (PMDB). Com Santa Catarina, de acordo com o presidente do grupo, Sérgio Antônio Garcia Amoroso, até agora ocorreram apenas contatos com prefeituras "de dois pequenos municípios", disse. "Estamos estudando questões de logística para definirmos onde será realizado o investimento", afirmou o executivo. Amoroso disse ainda que pontos como infraestrutura e incentivos fiscais também vão contar na hora de bater o martelo. ${ }^{17}$

\footnotetext{
${ }^{16}$ Artigo publicado no Jornal Folha de São Paulo, Caderno Dinheiro, em 30/06/06.

${ }^{17}$ Artigo publicado no Jornal Gazeta Mercantil, em 09/06/03.
} 
O que a imprensa chama de "suporte tributário" pode ser lido como isenção fiscal e descontos de tributação (consumo de água, energia, IPTU, doação de terreno), que se tornaram um forte componente da atual guerra fiscal, ou guerra dos lugares, como prefere Santos (2000), onde os estados e municípios disputam entre si a sede desses empreendimentos.

A chamada guerra fiscal está, na realidade, intimamente ligada ao grau de respaldo político que os estados podem conferir às empresas que ali se instalarem. Como os investimentos das grandes empresas do circuito são muitas vezes bilionários, o apoio dos governos onde elas se instalam é quase total. Os poderes legislativo, executivo e judiciário daquele estado dificilmente se voltarão contra a empresa. No caso deste circuito, tido como um dos mais poluidores, o rigor da legislação e da fiscalização ambiental de cada estado também conta como fator de atração.

Para ilustrar o funcionamento simbiótico dessa parceria vemos que, no discurso inaugural da Veracel, na Bahia, o diretor-presidente da empresa declarou:

Mas se alcançamos o mundo, com nossas exportações, nossa casa é aqui, neste acolhedor extremo sul da Bahia. Por isso, não posso deixar nesse momento, de também cumprimentar o Excelentíssimo Governador Paulo Souto, grande entusiasta desse projeto desde as suas etapas de concepção, que junto com um secretariado eficaz e com modernos sistemas de gestão, ajudou a Veracel com todo o apoio e ambiente favorável para aqui se instalar. Gostaria de destacar também, o apoio que temos recebido de várias autoridades deste Estado, incluindo parlamentares federais e estaduais e prefeitos da região, que tem formado uma grande rede de apoio à Veracel.(Renato Guéron, Diretor-Presidente da Veracel Celulose) ${ }^{18}$

Outra forma de política pública voltada para o circuito são as parcerias entre as empresas e as instituições públicas de pesquisa, como o IPEF (Instituto de Pesquisas e Estudos Florestais) e a Embrapa (Empresa Brasileira de Pesquisa Agropecuária). Empresas como Veracel, Aracruz, Cenibra, Eucatex, Klabin, Ripasa, Suzano Bahia Sul e Votorantin, são associadas do IPEF. Essas parcerias desenvolvem pesquisas relacionadas tanto ao melhoramento genético das espécies cultivadas como ao processo industrial de produção de celulose ou de papel, buscando sempre aperfeiçoar a qualidade do produto final. O IPEF, por exemplo, disponibiliza sementes selecionadas e mudas clonais, além de manter um amplo banco de material

\footnotetext{
${ }^{18}$ Discurso proferido por Renato Guéron, diretor-presidente da Veracel, por ocasião da inauguração da fábrica, em Eunápolis, em 28/09/05.
} 
genético. O instituto também oferece cursos para capacitação de mão-de-obra técnica qualificada, nas áreas de engenharia florestal e agronomia. E a EMBRAPA Floresta vem desenvolvendo o projeto genoma do eucalipto, base fundamental para outras pesquisas que visem, por exemplo, diminuir o tempo de crescimento das árvores e aumentar sua produtividade por hectare plantado.

A esses mecanismos de suporte operacional do circuito, citados neste capítulo, como os financiamentos oferecidos pelos bancos e as parcerias com os institutos de pesquisa, podemos chamar de círculos de cooperação (Santos, 1997). Segundo o autor, os círculos constituem um recorte analítico, que dá conta dos fluxos imateriais (como capital e informação), ligados ao processo de acumulação de um determinado circuito espacial produtivo. Além dos bancos e dos institutos de pesquisas científicas, o circuito produtivo de celulose também conta com outros agentes nos seus círculos de cooperação, dentre eles estão, por exemplo, empresas certificadoras de qualidade, firmas de consultoria jurídica, consultoria de mercado, agências de publicidade e assessoria de imprensa.

Contudo, se por um lado o circuito de papel e celulose ganha cada vez mais prestígio junto às esferas do poder público, especialmente aquelas ligadas ao planejamento e à economia, por outro, o setor está sendo alvo de fortes manifestações da sociedade civil organizada contra a expansão desse modo de produção das empresas, calcado na monocultura que se estende por vastas áreas, principalmente naqueles estados que convivem, há décadas, com a atuação dessas empresas, como no caso do Espírito Santo.

\section{3) O PAPEL DA SOCIEDADE CIVIL ORGANIZADA CONTRA A EXPANSÃO DA MONOCULTURA DO EUCALIPTO NO TERRITÓRIO CAPIXABA}

A partir dos anos 80, a população residente na Grande Vitória começa a sofrer com a poluição ambiental, decorrente das atividades industriais de grande porte, instaladas durante a década de 70 nas proximidades da capital. Grande concentração de partículas sólidas e gases tóxicos no ar, além de contaminações dos rios e do mar por efluentes das indústrias levaram a uma forte mobilização da população. No intuito de cobrar dos órgãos públicos uma 
fiscalização efetiva, e das empresas uma atitude ecologicamente correta, muitos moradores se associaram e se organizaram em organizações nãogovernamentais (ONG's) muito ativas, politicamente.

Essas organizações conseguiram, através de muita pressão política, a aprovação de uma legislação ambiental mais rígida no estado, transferindo para as empresas, inclusive a Aracruz Celulose (maior produtora de celulose do país e quinta maior do mundo), a responsabilidade de fazer as adequações mínimas nos procedimentos, de acordo com as novas exigências dos órgãos ambientais.

$\mathrm{Na}$ década de 90, essa fiscalização ganha reforço com as certificações e selos de qualidade, aferidos por instituições nacionais e internacionais, que passaram a ser cobrados, principalmente, pelos países consumidores da celulose produzida no país, ou seja, o mercado europeu e norte-americano.

Nossos clientes - entre os quais o editor americano de jornais Times Inc. ou o produtor de embalagens Tetrapak - não compram nossos produtos se não respeitarmos esse critério (estabelecido pelas empresas certificadoras),

afirma o Diretor para América Latina da Stora Enso, Nils Grafström ${ }^{19}$. É importante destacar que, no entanto, as exigências ambientais das fábricas do Hemisfério Norte são ainda mais rígidas que as aplicadas aqui, fato que tem atraído muitas multinacionais do circuito para o Cone Sul.

O uso do cloro elementar, por exemplo, muito usado no processo de branqueamento da celulose, foi abolido em todo o mundo. Contudo, no Brasil e na China, as fábricas têm utilizado o dióxido de cloro, que apenas minimiza mas não anula os efeitos devastadores das dioxinas (compostos organoclorados resultantes da associação de matéria orgânica e cloro) despejadas nos corpos d'água que recebem os efluentes, mesmo depois de tratados. A Europa já usa, há algum tempo, o branqueamento com oxigênio, água oxigenada e ozônio, processo conhecido como total chlorine free (TCF), muito menos degradante para o meio ambiente, mas também muito mais caro.

Mais recentemente, as certificações internacionais também começaram a abranger temáticas sociais, como por exemplo a exploração de trabalho infantil, envolvidas nos processos produtivos, em países como o Brasil. Logo,

\footnotetext{
${ }^{19}$ Em entrevista publicada no jornal Correio Popular, de Campinas, em 04/06/06, concedida à Agência France Press.
} 
as ONG's que lutam no Espírito Santo contra as expansões da monocultura do eucalipto empregados pela Aracruz, ganharam mais força ao se articularem com as organizações européias de consumidores conscientes, que cobram atitudes "socioambientalmente" corretas dos fabricantes.

Desde 1999, essas ONG's resolveram se associar e criaram a Rede Alerta Contra o Deserto Verde, atuando nos estados de Minas Gerais, Espírito Santo, Bahia e Rio de Janeiro, ou seja, na mesma área de atuação da Aracruz, com exceção do Rio Grande do Sul. A Rede, que está mais estruturada no Espírito Santo, é composta hoje por mais de cem entidades, movimentos, comunidades locais, sindicatos, enfim, todos preocupados com o aumento dos plantios de eucalipto em larga escala nos seus estados, promovidos não só pela Aracruz, mas por outras grandes empresas do circuito e também pelo governo federal, através do Programa Nacional de Florestas. São integrantes da Rede, por exemplo, a organização Federação de Órgãos para Assistência Social e Educacional (FASE), criada em 1961, que é originalmente do Rio de Janeiro mas mantém projetos regionais em vários estados, a associação Centro de Estudos e Pesquisas para o Desenvolvimento do extremo sul da Bahia (CEPEDES) e também a Associação dos Geógrafos Brasileiros (AGB) seção Vitória-ES.

A mais importante conquista da Rede, obtida recentemente, foi a retirada da certificação internacional, concedida pelo Forest Sterwardship Concil - Conselho de Manejo Florestal (FSC), a mais conceituada no mercado externo, dos produtos da Aracruz. Segundo Ferreira (2002),

O FSC é uma ONG internacional, fundada em 1993 no Canadá por cientistas, ambientalistas, produtores florestais e movimentos sociais (comunidades indígenas, populações florestais). A organização nasceu com o objetivo de qualificar o manejo florestal através do credenciamento de instituições que possam certificar operações florestais. Dentre as instituições certificadoras, temos órgãos governamentais e entidades privadas com e sem fins lucrativos. No Brasil, o FSC é constituído por: Câmara Social: Instituto Sócio-Ambiental (ISA), Vitae Civilis, FASE, Organização dos Seringueiros de Rondônia, Grupo de Trabalho Amazônico/Centro de Trabalhadores da Amazônia, Federação Nacional dos Trabalhadores da Indústria, Construção Civil e Madeira da (CUT); Câmara Ambiental: WWF, Funatura, IMAZON, Rede de ONG's da Mata Atlântica, Amigos da Terra-Programa Amazônia; Câmara Econômica: Sociedade Brasileira de Silvicultura, Associação Brasileira de Carvão Vegetal, Associação Brasileira dos Produtores de Papel e Celulose, Associação dos Exportadores de Madeira do Estado do Pará, Instituto de Pesquisas Tecnológicas, Federação dos Repositores Florestais do Estado de São Paulo. (Ferreira, 2002:181) 
A Rede Alerta se mobilizou para comprovar as denúncias de que a empresa se apropriou irregularmente de terras indígenas no município de Aracruz-ES e de terras de comunidades quilombolas e de pequenos agricultores no norte do Espírito Santo. Muitos foram expulsos de suas terras quando a empresa se instalou na região, outros ficaram completamente ilhados, cercados por imensas florestas de eucaliptos, sem estradas nem terras para cultivar. Também ficou comprovado que a empresa continua a praticar desmatamentos em áreas de preservação da Mata Atlântica no estado. Hoje, a Aracruz possui somente a certificação nacional CERFLOR, conferida pelo Instituto Nacional de Metrologia, Normalização e Qualidade Industrial (INMETRO), fortemente contestada com relação aos seus critérios de avaliação, além de não ser reconhecida internacionalmente. Contudo, como lembra Ferreira (2002), apenas a madeira extraída pela empresa das plantações do Espírito Santo é que perdeu a garantia de procedência do selo verde, conferido pelo FSC. A madeira extraída pela Aracruz no estado da Bahia, por ser de responsabilidade de outra razão social (Veracel Celulose), manteve o direito à esta certificação, a qual vem pleiteando.

A Rede condena o modelo agro-exportador do circuito, baseado em grandes extensões da monocultura e altamente mecanizado. Esse sistema, que para as empresas se constitui num ganho de produtividade incomparável, é na verdade insustentável, do ponto de vista social e ambiental, segundo as ONG's. Dentre as conseqüências apontadas pela Rede estão a baixa utilização da mão-de-obra, o incremento da concentração fundiária, o enorme volume de água que essa indústria demanda, a perda da biodiversidade local, o êxodo rural e a poluição, causada pelos agrotóxicos e dejetos.

Eles defendem a imediata diminuição dos plantios de eucalipto, que segundo a Rede, alimenta um consumo exagerado de papel pelos países desenvolvidos, os quais poderiam, sem muito esforço, diminuir bastante esse consumo. Também apóiam a reciclagem de papel, embora esta seja uma alternativa menos eficiente que a simples diminuição do consumo, pois também demanda o consumo de água e energia durante o processo.

A Rede Alerta luta para que a terra dos índios do município de AracruzES seja devolvida, assim como as propriedades dos quilombolas, no norte capixaba. Também propõem que a cultura do eucalipto seja substituída pela 
produção de alimentos nos moldes da agricultura familiar, defendendo, portanto, a realização da Reforma Agrária. A recuperação dos ambientes degradados pela poluição, promovida pela monocultura, especialmente a Mata Atlântica, constitui, da mesma forma, um dos seus grandes objetivos.

Os mapas a seguir mostram os principais conflitos sociais causados pela monocultura do eucalipto e foram elaborados por um estudo do Ministério do Meio Ambiente no qual a Rede colaborou com informações importantes.

\section{Mapa 2 - Conflitos sócio-ambientais}

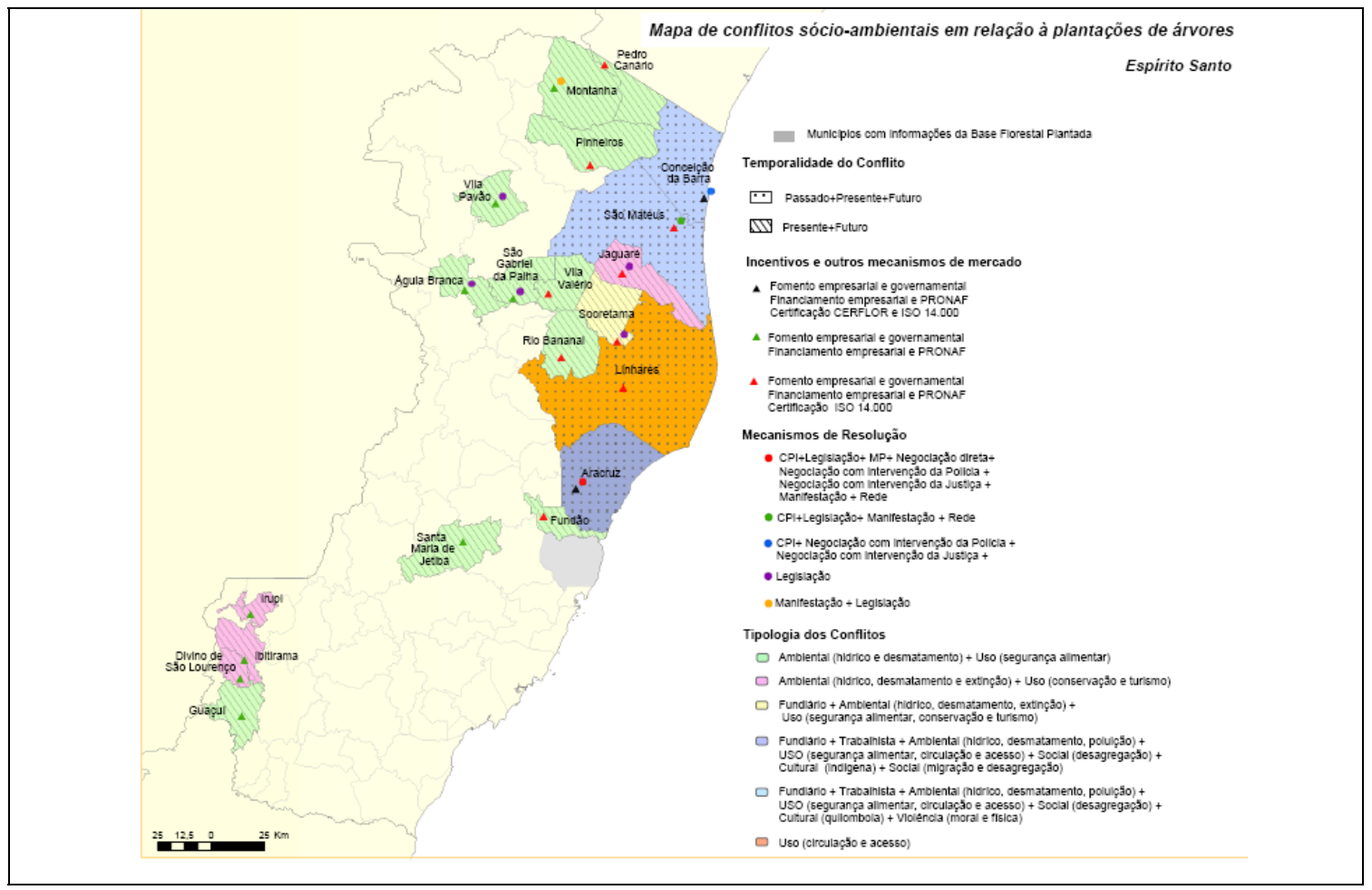




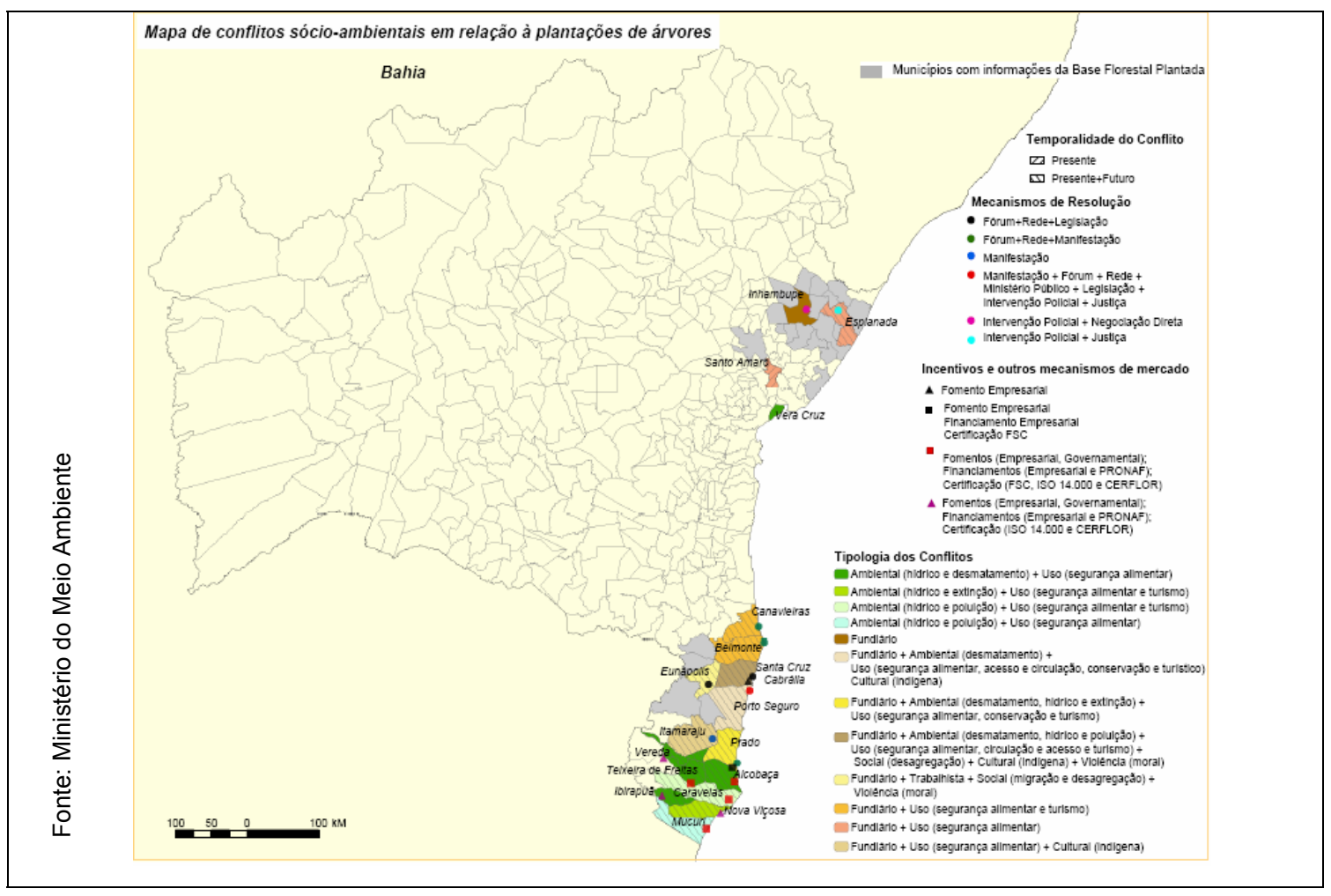

Para implementar e divulgar seus objetivos, a Rede organiza debates nas comunidades afetadas, promove campanhas, mobilizações públicas e materiais informativos, além de estabelecer freqüentes intercâmbios com organizações e especialistas internacionais. E por ser uma associação ativa e participativa que já existe há sete anos, a organização possui certo apoio político, representado no poder legislativo do estado por alguns deputados que acreditam nas proposições da associação. Foram esses deputados que conseguiram aprovar, em 2001, a proibição de novos plantios de eucalipto no estado enquanto não fosse realizado o zoneamento agro-ecológico, embora o poder político da Aracruz Celulose no Espírito Santo seja muito maior. A empresa é uma das maiores financiadoras de campanhas eleitorais do estado.

Por outro lado, há uma lacuna importante na atuação da Rede e de outras organizações ligadas ao tema do combate à monocultura do eucalipto. É latente a falta de diálogo direto entre as organizações e as empresas por elas criticadas. Existe um distanciamento natural nos discursos, afinal, os interesses dos dois agentes são opostos, mas também não há canal algum de comunicação entre as partes. Ambos os agentes são informados sobre os posicionamentos do outro principalmente através da mídia. As empresas e as 
organizações souberam construir pontes de relacionamento estreito com o poder público capixaba, mas não entre si. Segundo Fanzeres (2005),

De maneira resumida, o contexto dos conflitos sócio-ambientais em relação a plantações de árvores, que se expressa em sua integralidade no eixo norte do Espírito Santo - extremo sul da Bahia, é que se, por um lado, as empresas entronizam o discurso de promoção do desenvolvimento rural, por outro lado, camponeses e populações tradicionais, (...) ocupantes históricos desta região, não se percebem inseridos neste modelo agro-exportador. Neste cenário cresceram as empresas articulando e utilizando forças políticas e econômicas em seu favor. Do outro lado, especialmente após a restauração da democracia no país, se organizaram e ramificaram organizações da sociedade civil, como porta-vozes de interesses ambientais e sociais. Estes são os atores que atualmente se confrontam, mesmo sem a utilização de uma arena comum. Na verdade, no processo de elaboração deste Diagnóstico foi constatado que estes atores vivem e constroem suas percepções em universos paralelos. $E$ os momentos de convergência, que eventualmente ocorrem, estão relacionados à eclosão de conflitos sócio-ambientais. (Fanzeres, 2005:49)

As organizações civis, contudo, não podem mais culpar as empresas do circuito por dificultar esse diálogo, pois tem sido justamente elas que têm se esforçado para estabelecer uma comunicação direta, abrindo a empresa inclusive para pesquisas científicas. As firmas fizeram essa aproximação no intuito de mudar sua imagem junto à sociedade, comumente associada à degradação ambiental, como estratégia de marketing. Porém, as organizações não estão sabendo aproveitar essa abertura para, através da interlocução direta com as empresas, construir propostas que beneficiem o lugar, a região. Ao se colocarem, de maneira intransigente, contra qualquer atividade industrial que implique em reflorestamento com espécies exóticas, como o eucalipto, essas organizações da sociedade civil perdem, de pronto, o apoio irrestrito de outras parcelas da sociedade e mesmo do Estado.

É importante exigir das grandes empresas do setor, no mínimo, que obedeçam ao zoneamento agro-ecológico (que corresponde ao planejamento do uso do solo agricultável) vigente e que respeitem o direito à terra das comunidades tradicionais indígenas e quilombolas, garantidas por lei. Esse já seria um grande passo na direção de estabelecer práticas de compensação dos lugares e regiões que já abrigam o circuito produtivo de celulose.

Contudo, a manutenção da base industrial de um território também deve ser visto como aspecto positivo, gerador de empregos, tributos, riquezas. Além disso, o circuito produtivo de celulose brasileiro desenvolve pesquisas tecnológicas de ponta, acumulando conhecimento científico nacional. 0 exemplo mais notório é o do uso do eucalipto na produção de celulose de fibra 
curta, espécie considerada inadequada pelos países produtores tradicionais e que, no entanto, hoje é considerada uma unanimidade entre os principais produtores, graças aos pesquisadores brasileiros. Portanto, não é construtiva a bandeira das organizações civis que se opõe radicalmente contra as indústrias de celulose e suas áreas cultivadas. Afinal, se temos que produzir papel (e a humanidade não dispensa o uso dessa mercadoria desde sua invenção moderna, há cerca de dois mil anos), que seja com o uso de matéria-prima cultivada, e não com as nossas florestas nativas, já tão escassas.

O principal entrave desse circuito produtivo está, na realidade, na grande demanda por vastas extensões de terra de propriedade das empresas (aumentando a concentração fundiária, que, em algumas regiões do país, ainda é a regra), pois ao se constituírem como suas próprias fornecedoras de madeira, as empresas garantem seu abastecimento sem depender de terceiros e controlam o preço da sua matéria-prima. Esta é a maior e mais importante vantagem competitiva das empresas de celulose instaladas nos países subdesenvolvidos. A prática do fomento florestal somente se torna interessante para as empresas quando o preço da terra, na região onde as empresas se instalaram, já atingiu patamares muito elevados (devido ao processo inflacionário gerado pelas próprias empresas). Porém, nunca constituirá a principal fonte fornecedora de madeira para as fábricas.

No entanto, a atitude mais condenável, com relação aos investimentos do capital produtivo desse circuito, como no caso da Veracel, é a disponibilização de recursos (financiamento público, isenções fiscais, mão-deobra especializada e barata, condições biogeográficas favoráveis, logística territorial adequada e know how tecnológico) nacionais para subsidiar custos de um comércio intra-empresa, onde a Stora Enso produz a celulose de que necessita na Bahia e a industrializa (aumentando bastante o valor agregado) nas suas próprias fábricas chinesas, a custos praticamente nulos.

Logo, nos parece pouco provável que a monocultura do eucalipto e o poder das empresas deste circuito no país vão diminuir, em benefício das pequenas propriedades e da produção de alimentos, assim como não é desejável pensar que não deveríamos ter indústrias produtoras de celulose no território brasileiro, sejam de capital nacional ou estrangeiro. O verdadeiro papel das ONG's, como a Rede Alerta, além de denunciar as irregularidades 
cometidas pelas empresas, é, sobretudo, dificultar a sua livre ação. A cobrança de normas que disciplinem o plantio do eucalipto, como a lei de zoneamento agro-ecológico (inexistente na Bahia) junto ao poder público é um bom ponto de partida. Além disso, deve ser estabelecido um canal de negociação freqüente, envolvendo as organizações civis locais, o poder público local e as empresas, sobre as contrapartidas de investimentos destas (especialmente em infra-estrutura urbana e saneamento), nas cidades e regiões que abrigam esses empreendimentos (e o grande contingente populacional que para elas se dirige), contudo, fora do contexto de responsabilidade socioambiental.

De acordo com essa prática empresarial, hoje tão difundida entre as grandes corporações, as empresas é que escolhem onde, em que área, para quem e por quanto tempo desenvolverão suas ações socioambientalmente responsáveis, que retornam como imagem positiva das empresas junto à sociedade. Numa negociação que envolvesse a sociedade civil organizada diretamente atingida por esses empreendimentos do circuito de celulose, 0 poder público local e estadual e as empresas envolvidas, essas escolhas não caberiam mais somente às empresas, mas sim aos interesses locais, revelando as potencialidades da resistência do lugar (Santos, 1996).

\section{4) ConsolidaçÃo da empresa Aracruz Celulose, a especializaçÃo PRODUTIVA DO TERRITÓRIO CAPIXABA E SUA EXPANSÃO PARA O SUL DA BAHIA}

No final da década de 60, o território do estado do Espírito Santo foi sendo preparado para receber a industrialização, tendo em vista a grande crise que atravessava a economia cafeeira, que até então, era a principal atividade econômica do estado. Em 1969, foi construído e pavimentado o trecho da BR101 que atravessa todo o estado e o interliga com a chamada "região concentrada", além de terem concluído, na mesma época, a BR-262, que liga Vitória-ES a Belo Horizonte-MG, antes interligadas apenas pela ferrovia "Vitória a Minas". As duas rodovias foram decisivas para a efetivação da integração viária do estado com a economia nacional. No início dos anos 70 , é inaugurado o porto de Vitória e o estado recebe investimentos na ampliação da rede elétrica. Além disso, a lei federal de incentivo ao reflorestamento no país, instituída em 1966, teve ampla aceitação no estado, tanto que, em 1967, é 
criada a Aracruz Florestal, embrião da Aracruz Celulose, fazendo os primeiros plantios de eucalipto.

O Espírito Santo já abrigava a sede da Companhia Vale do Rio Doce (CVRD) quando o governo federal cria, durante a década de 70 , a série de Grandes Projetos para o estado, inspirado no modelo dos "pólos de desenvolvimento", entre eles: o pólo siderúrgico; o complexo naval; o complexo portuário; e, por fim, o complexo paraquímico, dentro do qual estavam previstos a criação da Aracruz Celulose, fruto da associação de empresários locais e bancos nacionais, e da Flonibra, numa associação entre a CVRD e a Japan Brazil Pulp, empresa japonesa.

Segundo o planejamento estatal, a Aracruz, localizada próximo à Vitória, produziria celulose branqueada para abastecer, inicialmente, o mercado interno. E a Flonibra, que se instalaria no norte do estado, na região de São Mateus, produziria celulose em polpa e cavacos de madeira ("chips") para exportação. A Flonibra acabou não se concretizando, mas a associação entre a CVRD e a empresa japonesa concluiu uma unidade produtiva de celulose em Minas Gerais, no município de Belo Oriente, a Cenibra. Além disso, na década de 80, a CVRD comprou terras no sul da Bahia, no intuito de implantar ali uma nova unidade produtiva de celulose, denominada BahiaSul, que também não se concretizou na época.

Criada em 1972, a Aracruz Celulose foi instalada no município de Aracruz-ES, a oitenta quilômetros de Vitória, próximo à costa. O local escolhido apresentava boas condições edafo-climáticas para o desenvolvimento da monocultura, topografia plana favorável à mecanização, e era também uma região de economia pouco expressiva, embora tivesse boa localização quanto ao sistema viário e era próximo ao mar, facilitando o escoamento da produção pelo porto de Barra do Riacho -ES.

Definida a localização da fábrica, a empresa começou a adquirir terras nas áreas próximas, processo que desencadeou uma forte especulação imobiliária na região, encarecendo o preço da terra. A fim de evitar os altos preços, a Aracruz passou a comprar terras na região de São Mateus e Conceição da Barra, no norte do Espírito Santo, próximas da divisa com o estado da Bahia. Esta seria a área de atuação da Flonibra, que, como acabou 
não se concretizando, vendeu suas áreas já reflorestadas para a Aracruz, a qual adquiriu também áreas próprias no sul da Bahia neste período.

Esses investimentos fundiários foram financiados pelo então BNDE, o qual também ajudou nos gastos com a construção da fábrica, que só começou a ser construída em 1975 e a operar, em escala comercial, em 1979, com uma produção de 400 mil toneladas por ano. É importante ressaltar que o Estado desempenhou, portanto, um papel fundamental no desenvolvimento recente da indústria de celulose, assim como o fez nos anos 50. Para tanto, o Governo instituiu os incentivos fiscais ao reflorestamento, estruturou o modelo exportador (centrado na concessão de isenções fiscais às atividades exportadoras) e viabilizou a concretização de megaprojetos como a Aracruz. Todos esses feitos vieram na esteira do II Plano Nacional de Desenvolvimento e, mais especificamente, do Programa Nacional de Papel e Celulose, que visava transformar o país de importador de celulose em uma potência do mercado externo nesse produto. O objetivo foi alcançado num curto espaço de tempo, pois em menos de dez anos de operação, a Aracruz já era exportadora de celulose.

Na década de 80, a empresa inicia seu programa de fomento florestal, que se revelou uma boa estratégia de aumento de produção, sem o ônus da aquisição de mais terras. Dessa maneira, a Aracruz se estabelece como a única unidade produtiva de celulose do território capixaba, dona de cerca de cem mil hectares no estado, sem contar a sua rede de fomentados. Segundo Dalcomuni (1990), nesse período, a Aracruz também já era detentora de mais cinqüenta mil hectares no extremo sul da Bahia, estendendo seus domínios para além do Espírito Santo.

Segundo denunciam algumas ONG's capixabas, esta empresa desmatou a área de Mata Atlântica no local onde construiu a fábrica, e expulsou aldeias indígenas inteiras de suas terras para ocupá-las com as plantações de eucalipto. Também há denúncias de práticas de coação da empresa sobre os proprietários de terra, que foram obrigados a vender suas terras para a Aracruz Florestal, subsidiária da Aracruz Celulose. A empresa, contudo, nega essas acusações.

Em 1985, a Aracruz, juntamente com a Cenibra (CVRD), participam da privatização do terminal portuário de Barra do Riacho-ES (distrito do município 
de Aracruz), até então controlado pela empresa estatal Portobrás. A celulose produzida tanto pela Cenibra como pela Aracruz, são exportadas por esse terminal, sendo que a produção mineira chega ao porto por meio da Ferrovia Vitória a Minas (EFVM, pertencente à CVRD) e a capixaba chega de caminhão, trazida da fábrica, que fica a dois quilômetros do porto. A Aracruz controla, até hoje, $51 \%$ e a Cenibra $49 \%$ dos ativos do Portocel, novo nome dado ao porto. O mapa abaixo ilustra os fluxos de celulose transportados pelo terminal.

\section{Mapa 3 - Fluxo de celulose movimentado pelo Terminal Marítimo Portocel}

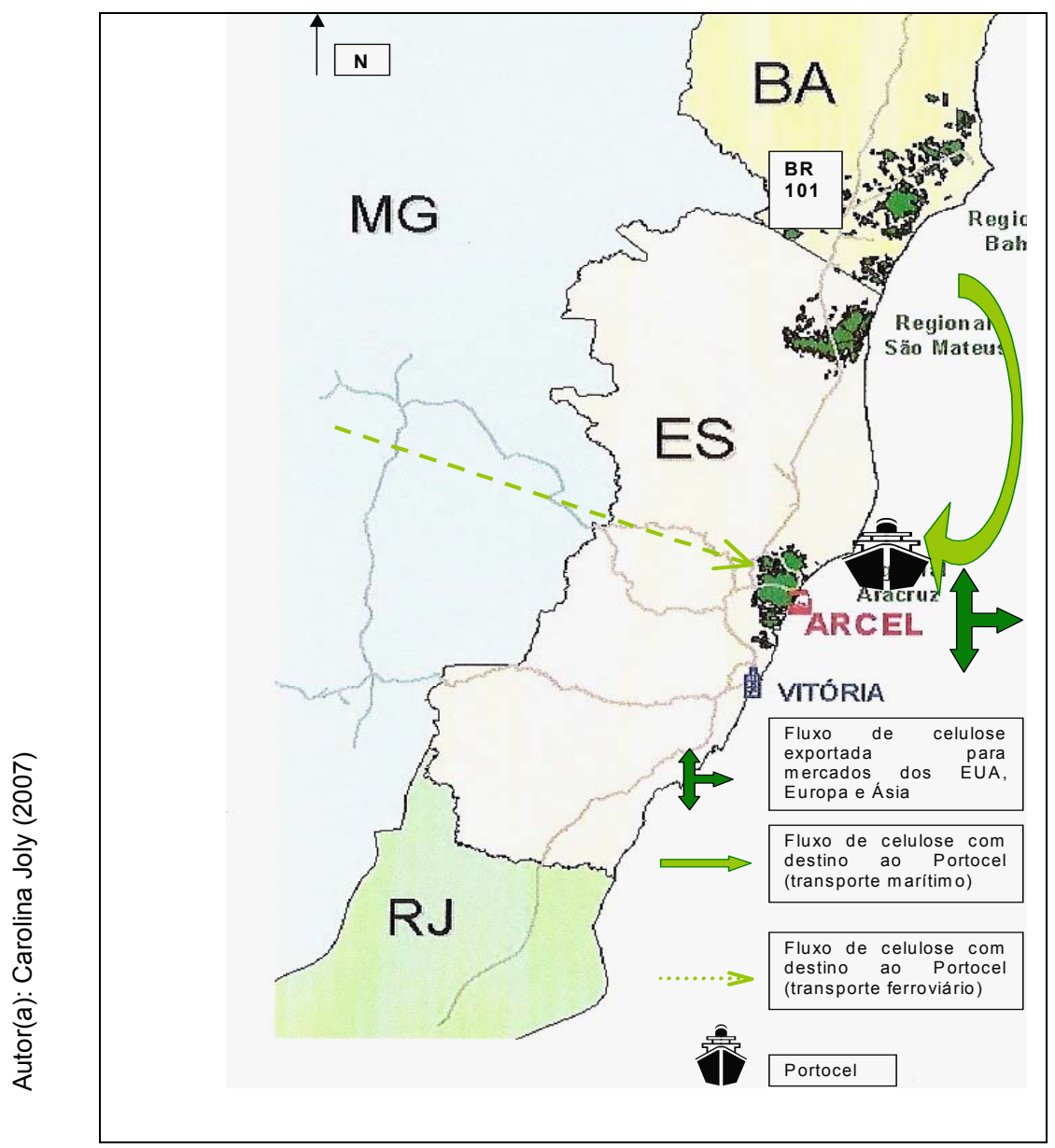

Este porto também opera recebendo alguns insumos usados na fabricação da celulose, como o sal, por exemplo. Uma vez por mês chega um navio carregado de sal, na maioria das vezes vindo de Mossoró-RN, outras de Cabo Frio-RJ, destinado à produção de celulose da Aracruz. O porto também recebe carregamentos de água oxigenada, que é descarregada por dutos 
acoplados ao navio e que vão até a fábrica da Aracruz. Na década de 90, o terminal portuário sofreu várias ampliações, conforme a Aracruz aumentava sua produção. Hoje, o Portocel é um dos portos mais especializados em transporte de celulose do mundo. As fotos abaixo ilustram as operações de movimentação de carga feitas no terminal.

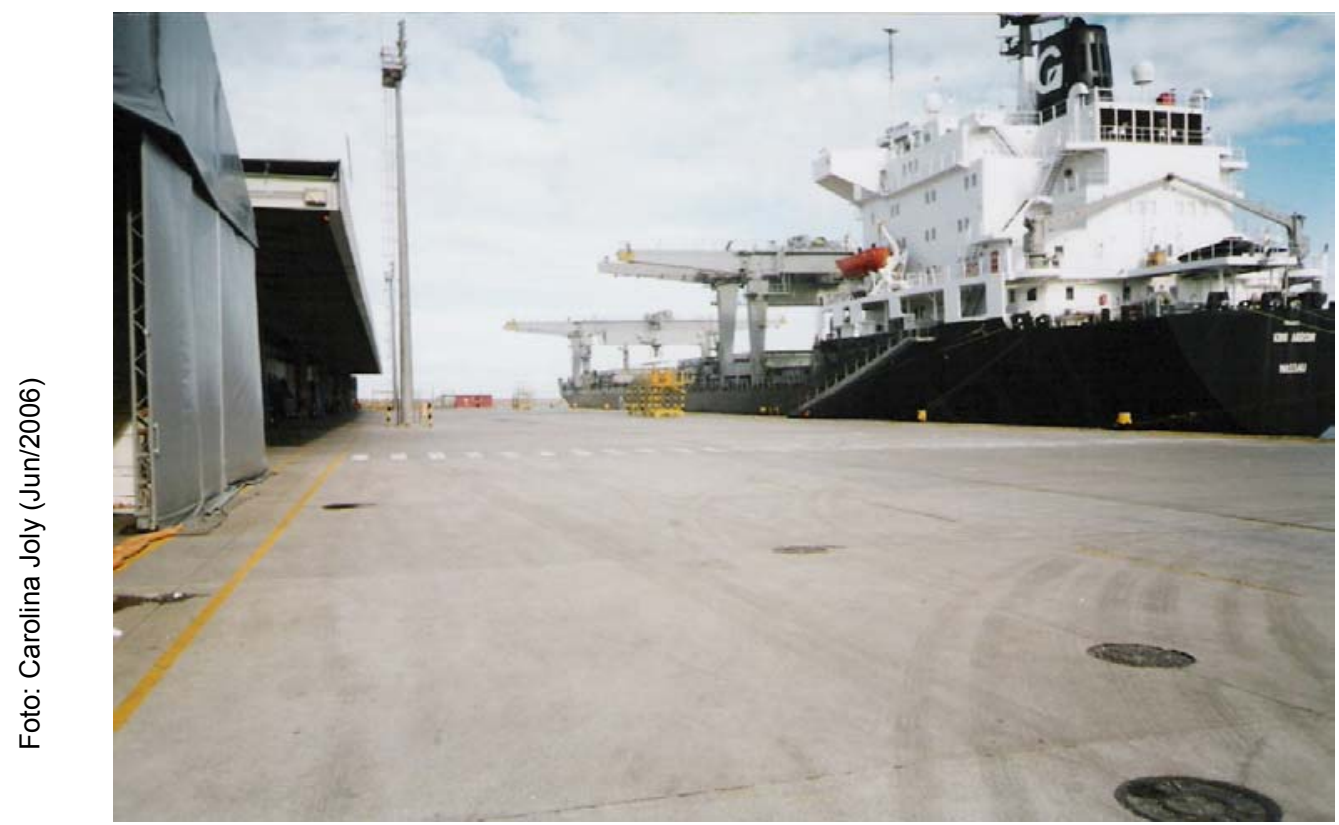

Figura 1 - Navio cargueiro atracado no terminal de embarque do Portocel, pronto para receber o carregamento de celulose.

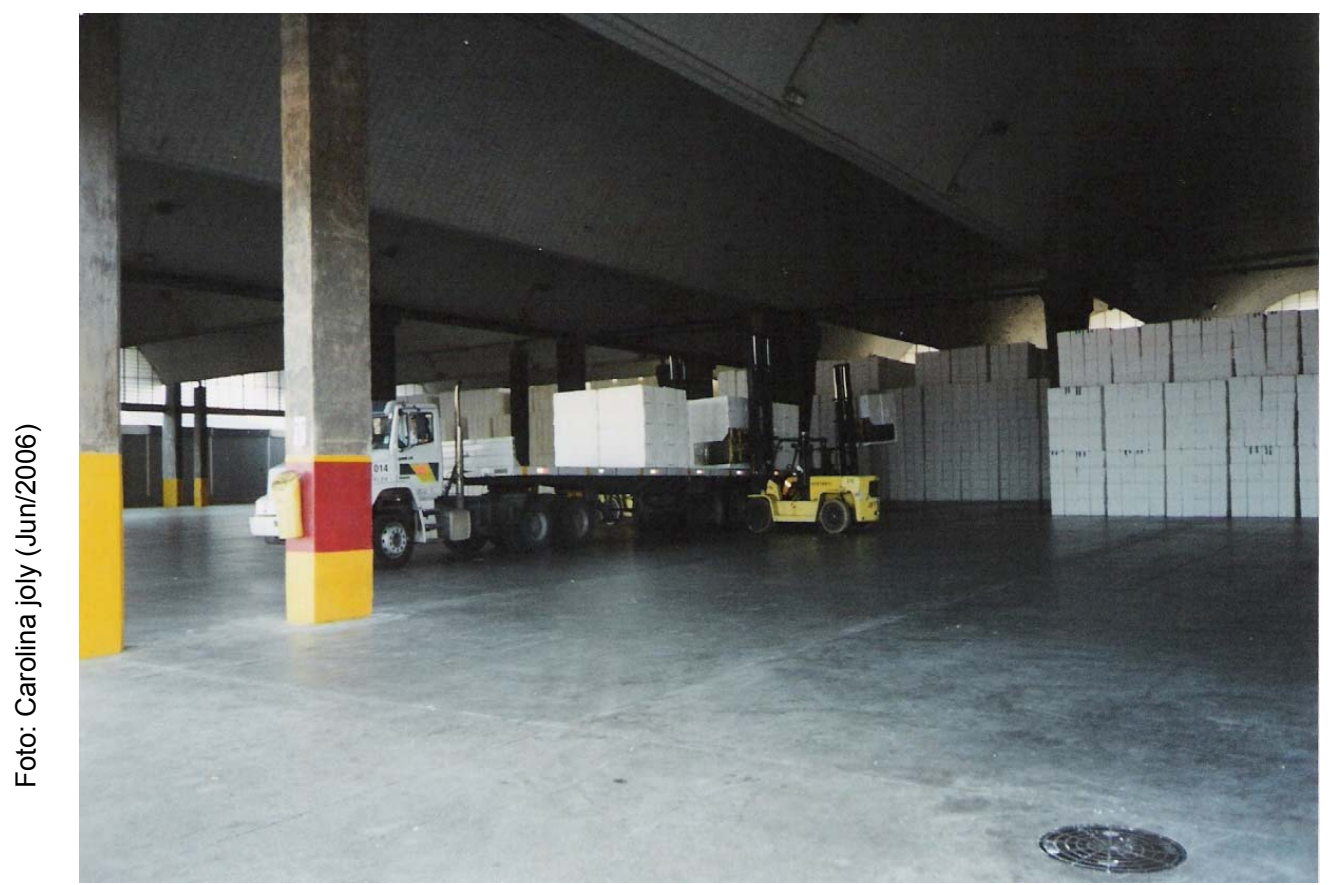

Figura 2 - Um dos galpões de armazenamento dos fardos de celulose já embalados, localizado no terreno do Portocel. 
Ainda na década de 90, a Aracruz Celulose amplia significativamente a sua produção, inaugurando nesse período a fábrica $B$, junto da planta inicial, além de grandes projetos de modernização da produção. O seu escritório comercial, por exemplo, foi transferido para São Paulo, onde hoje estão concentrados seus altos executivos, os contatos com clientes e suas operações financeiras.

Nessa época, chegou a produzir 1,24 milhões de toneladas de celulose por ano, das quais $98 \%$ tinham como destino o mercado externo. A seguir, uma imagem atual da planta da empresa em Aracruz-ES, tendo o terminal Portocel ao fundo, mostra a dimensão do empreendimento.

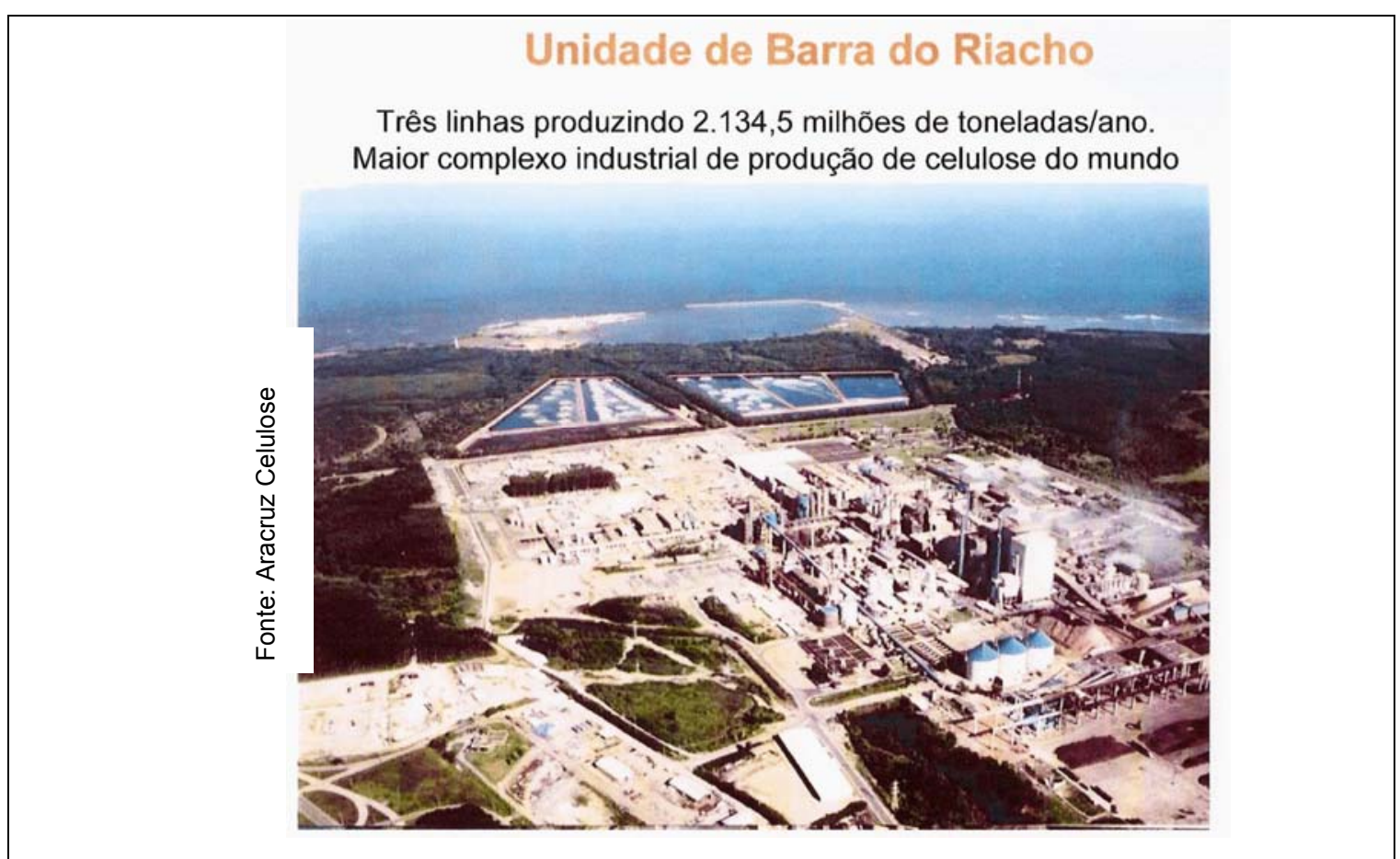

Figura 3 - Foto aérea do complexo produtivo da Aracruz Celulose, no município de Aracruz - ES.

\section{Como aponta Dalcomuni (1990):}

É importante ressaltar ainda que se, por um lado, a implantação dos "Grandes Projetos" no Espírito Santo proporcionou uma significativa elevação no volume e valor da produção industrial no estado, ampliando a oferta de emprego no setor secundário e por essa via influenciando na circulação de renda na "economia capixaba", por outro lado, dado ao grande porte dos mesmos, e à forma concentrada no tempo e espaço com que foram implantados, esses projetos provocaram profundas alterações na estrutura econômica, social e política no Espírito Santo. Estas transformações referem-se principalmente aos processos de concentração industrial, concentração fundiária, modificações no uso do solo e relações de trabalho na agricultura, concentração urbana e agudização de problemas ambientais suscitados pelos mesmos. (Dalcomuni, 1990:209). 
Ao vivenciar essas intensas transformações trazidas com a instalação da Aracruz, parte da sociedade civil do Espírito Santo, como já detalhamos no capítulo 2.3, se organizou em ONG's que combatem as ações da empresa, tentando evitar que sua abrangência de atuação se ampliasse ainda mais no território capixaba. Com o apoio dessas associações, foi aprovada, em 2001, uma lei estadual ( $\left.n^{\circ} 6.780 / 01\right)$ que proibia a Aracruz Celulose de comprar mais terras e de realizar plantios de espécies exóticas (entre elas, o eucalipto) no Espírito Santo, até que fosse elaborado um zoneamento agro-ecológico do estado. Apesar do forte apoio político que a empresa possui no estado, essa lei conseguiu vigorar até 2003, quando se iniciou o primeiro mandato do atual governador reeleito, Paulo Hartung, entusiasta dos "Grandes Projetos" do estado.

Apesar de momentânea, essa proibição interferiu diretamente nos planos de imediata ampliação da fábrica de Aracruz - ES, onde a empresa pretendia inaugurar o complexo $\mathrm{C}$, que elevaria a capacidade total da planta de Aracruz $(A+B+C)$ para dois milhões de toneladas por ano. A Aracruz também pretendia, ao que parece, instalar uma nova unidade produtiva no Espírito Santo, fora do município de Aracruz. Com a aprovação da lei, ela se voltou então para o sul da Bahia, onde já possuía grandes extensões de terras desde os anos 80 , inclusive com plantios de eucalipto.

Ao receber total apoio do governo baiano, a Aracruz decide instalar no sul da Bahia sua nova unidade produtiva (a Veracel), em parceria com a multinacional Stora Enso. O próprio Diretor de Engenharia da empresa, afirmou $^{20}$ :

Os problemas políticos no ES, no final da década de 90 , e as restrições aos aumentos de florestas comerciais para fins de produção de eucalipto levaram-nos a investir no estado vizinho, visto que essas dificuldades eram dirigidas, especificamente, à Aracruz Celulose. No final dos anos 90, como já tínhamos áreas plantadas no sul da Bahia, o Grupo Odebrecht tinha uma parceria com a Stora Enso neste estado que era de $50 \%$ para cada um (em relação ao empreendimento Veracel). Então, compramos parte da participação da Odebrecht, ficando, num primeiro momento, a seguinte situação: Aracruz 45\%, Stora Enso 45\% e Odebrecht 10\%. Em 2003, a Odebrecht vendeu seus $10 \%$ e a constituição passou a ser a de hoje, $50 \%$ para Stora Enso e 50\% para Aracruz.

As terras que a Aracruz Celulose detinha em território baiano já eram na região de Eunápolis e Porto Seguro, pois desde os anos 70 , as terras mais ao

\footnotetext{
${ }^{20}$ Em entrevista realizada em 08/06/06.
} 
sul, próximas da divisa com o Espírito Santo na região de Teixeira de Freitas $B A$, já pertenciam à CVRD, dona da fábrica de papel e celulose Bahia Sul, que operava desde os anos 80 na região. Em 1997, com a privatização da CVRD, a Bahia Sul, cuja fábrica está instalada no município de Mucuri-BA (divisa com o Espírito Santo), foi comprada pela empresa paulista Suzano. Sua produção atual passará de seiscentas mil toneladas anuais para 1,4 milhão de toneladas de celulose por ano, depois do processo de duplicação, pelo qual está passando no momento. A Veracel, que hoje produz novecentas mil toneladas por ano de celulose, em breve também será ampliada, passando a produzir 1,2 milhão de toneladas anuais.

Ambas fazem uso do programa de fomento florestal no território baiano, mas cerca de $80 \%$ da produção estão concentradas em terras próprias das empresas. Atualmente a Aracruz possui agricultores fomentados nos estados do Espírito Santo, Minas Gerais, Bahia e Rio Grande do Sul. Ao todo, são oitenta e um mil hectares, espalhados por 145 municípios do país. Em 2005, também foram incluídos no programa treze municípios do norte fluminense, na região de Campos dos Goitacazes-RJ. Na realidade, a subcontratação na fase florestal (fomento) não se constitui em padrão da produção no oligopolizado mercado mundial do produto, onde a manutenção de base florestal própria constitui-se em um dos principais fatores de concorrência.

A principal inovação logística, demandada pela expansão da abrangência territorial da especialização produtiva, que hoje engloba do centro-norte do Espírito Santo até o extremo sul da Bahia, foi instituída pela empresa Aracruz. O "pulo do gato" está nas operações de transporte, com a inauguração do terminal de barcaças no Portocel, em 2003. Ao adaptar o modelo de embarcação usada em navegação fluvial nas hidrovias, a Aracruz passa a fazer uso da navegação de cabotagem, trazendo para Aracruz-ES madeira do seu porto em Caravelas-BA (para seu abastecimento) e celulose da Veracel (para ser exportada) diretamente do sul da Bahia através do oceano, dispensando o transporte rodoviário, usado até então. A produção da BahiaSul, depois de concluída sua ampliação, também será transportada nas barcaças até o litoral capixaba para, então, ser exportada.

Pouco utilizada no território nacional, a navegação de cabotagem é extremamente mais barata que o modal rodoviário, transformando-se numa 
expressiva vantagem comparativa da empresa. Atualmente, a Aracruz possui quatro barcaças, um rebocador e um empurrador. Cada barcaça transporta o equivalente a cem carretas e a empresa pretende, em breve, obter mais duas barcaças. As fotos abaixo ilustram o funcionamento logístico dessas embarcações atracadas no terminal portuário de Barra do Riacho - ES.

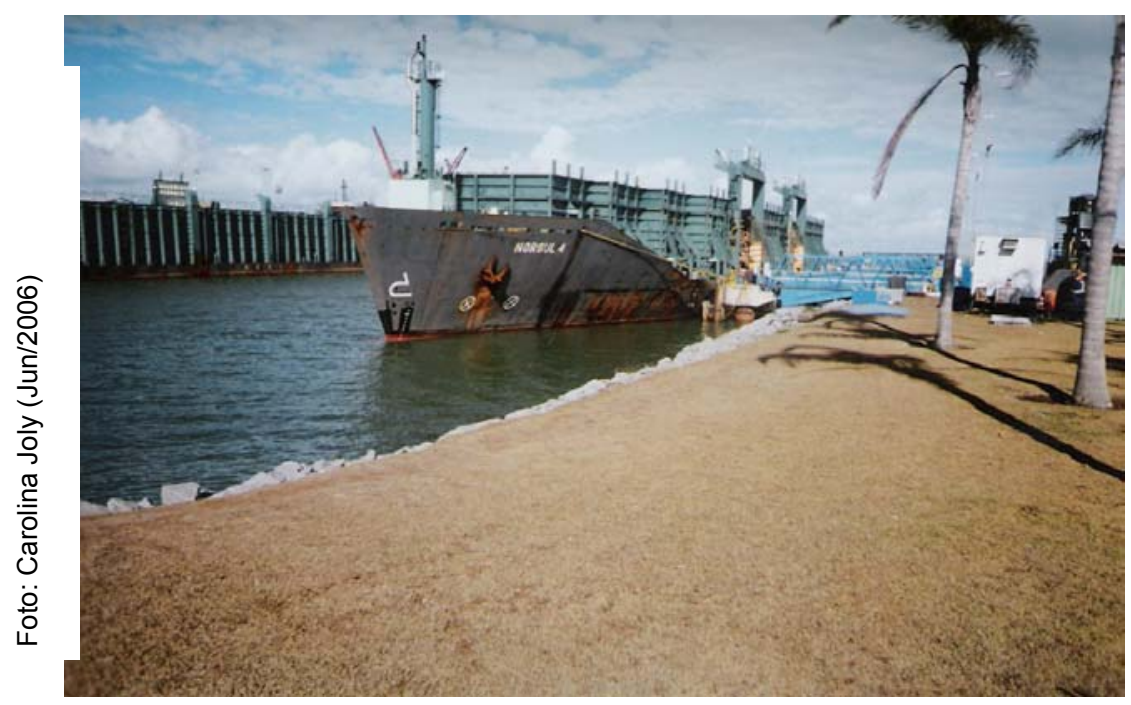

Figura 4 - Barcaça atracada no Portocel para retirada do carregamento de madeira que trouxe da Bahia.

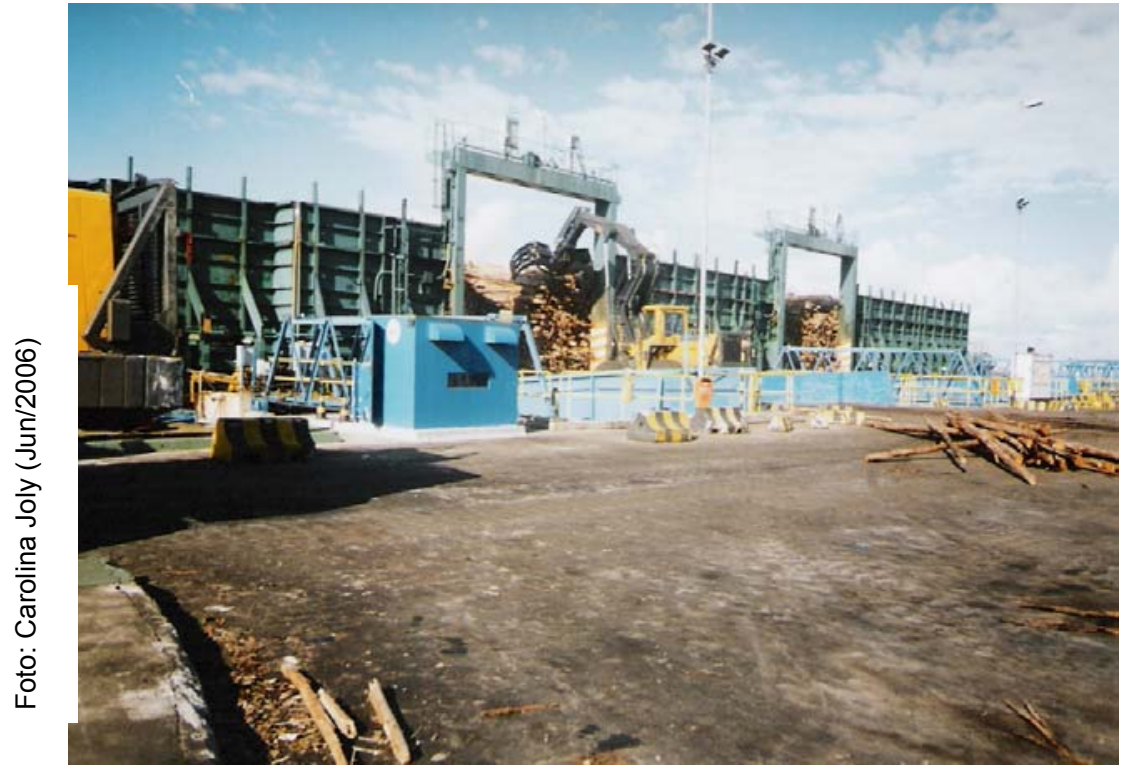

Figura 5 - Máquina retira toras de madeira pela lateral da barcaça, vinda da Bahia. 


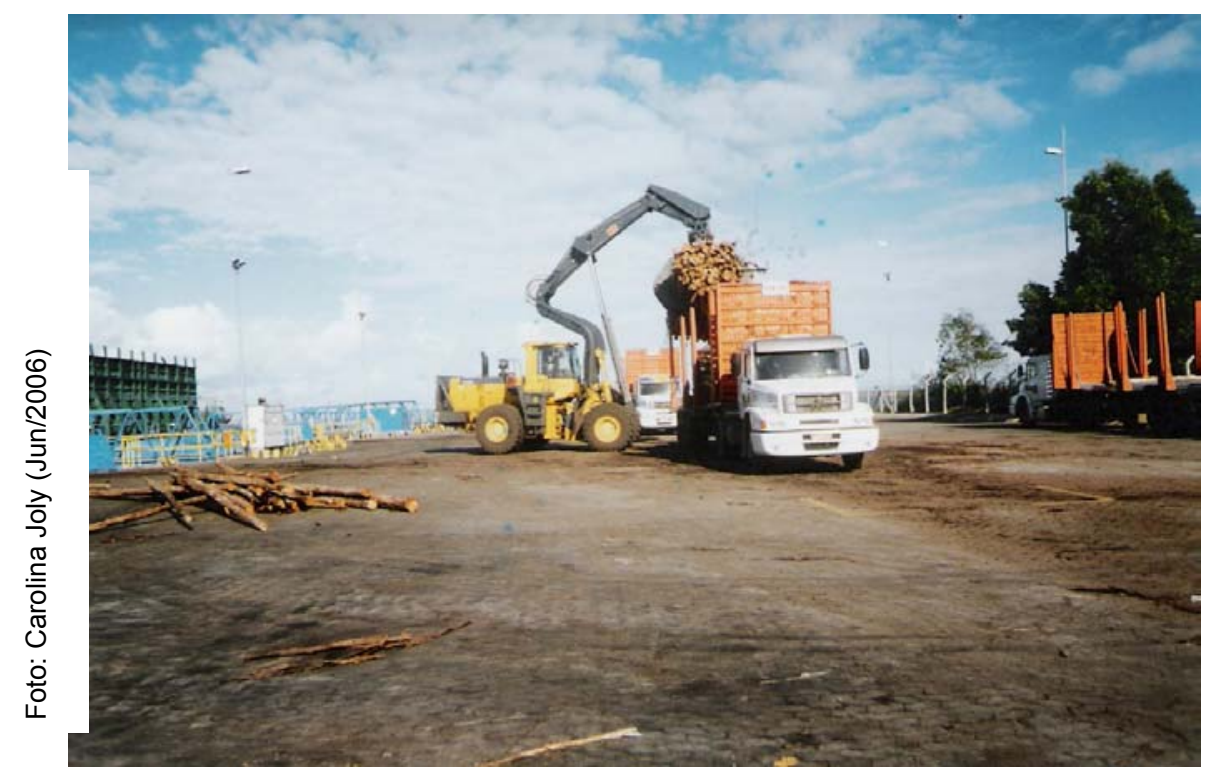

Figura 6 - Carregamento de madeira retirado da barcaça com destino à fábrica da Aracruz Celulose, transportado por caminhões adaptados.

Dessa maneira, é possível compreender como a Aracruz Celulose foi expandindo sua área de atuação em direção ao sul da Bahia, na verdade uma continuação territorial do estado do Espírito Santo. A especialização produtiva dessa região entre o norte capixaba e o sul baiano dotou o território de novos e modernos objetos técnicos, como esse terminal de barcaças e a própria fábrica da Veracel, tida como uma das mais modernas do mundo.

Esses investimentos fizeram da Aracruz a maior produtora mundial de celulose de fibra curta de eucalipto, responsável pelo abastecimento de cerca de $30 \%$ do mercado internacional desse produto ${ }^{21}$. A empresa vive hoje a maior fase de crescimento da sua história, tendo lucrado no ano de 2005 cerca de $\mathrm{R} \$ 1,7$ bilhões, um recorde em sua história. Sua composição acionária atual é a seguinte: Grupo Lorentzen 28\%, Grupo Votorantin 28\%, Grupo Safra 28\%, BNDESpar $12,5 \%$ e acionistas minoritários $3,5 \%$. O mapa abaixo ilustra a atual topologia da Aracruz Celulose e evidencia seu caráter multinacional.

\footnotetext{
${ }^{21}$ Somando a produção de todas as suas unidades em Aracruz-ES $(A+B+C)$, a da Veracel (50\%) e da Riocell (Guaíba-RS), a Aracruz Celulose produz hoje três milhões de toneladas por ano de celulose.
} 


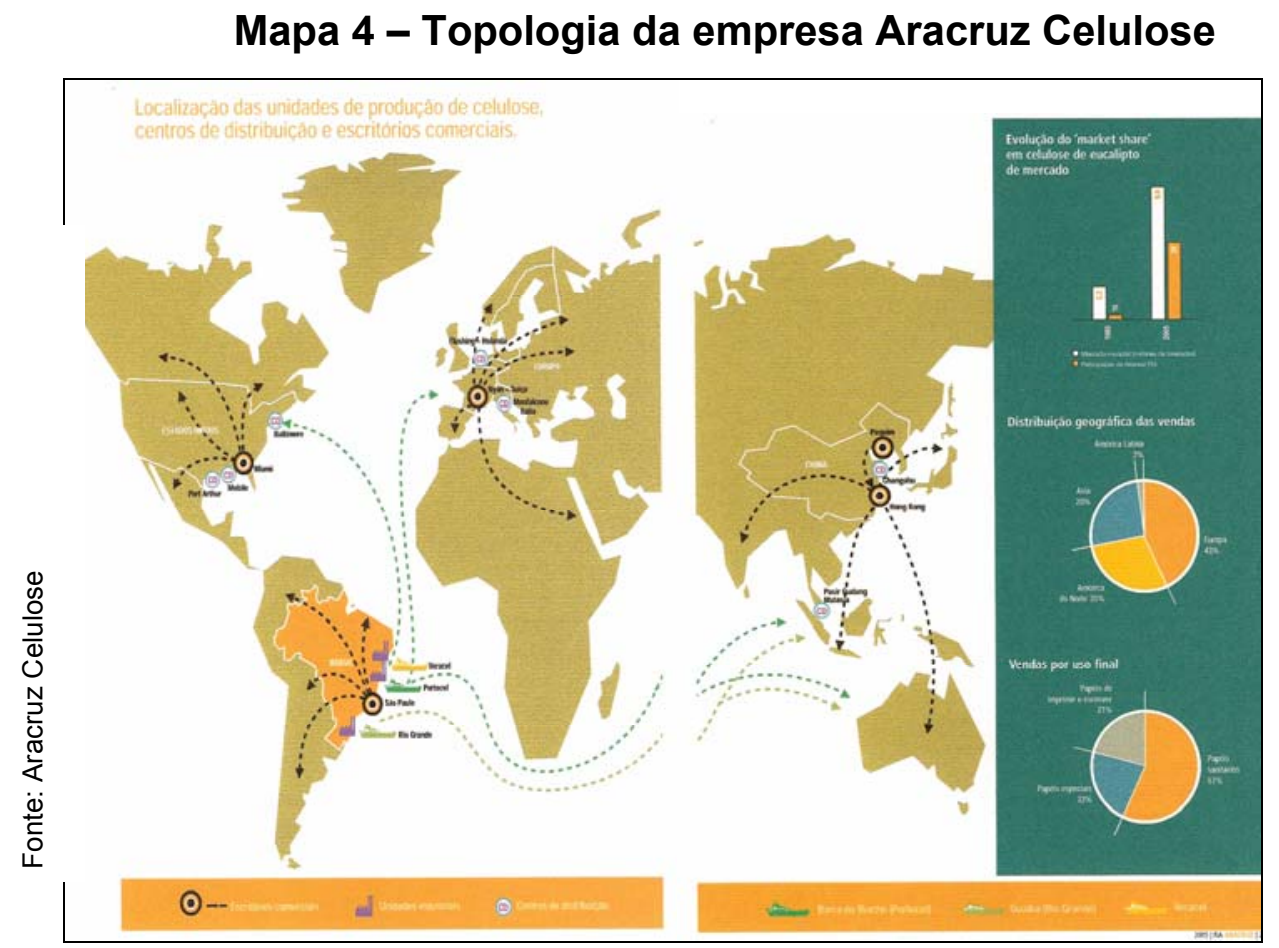

A continuidade do aumento gradual de preços internacionais da celulose projeta bons resultados para o circuito, de maneira geral. O setor opera hoje no Brasil com $93,6 \%$ da capacidade instalada ${ }^{22}$, ou seja, a demanda por celulose e por novas fábricas no país é forte no atual período. Porém, é preciso lembrar que a celulose, ou a madeira, são commodities, têm seu preço balizado pelos níveis das reservas internacionais desses produtos, que no momento, estão abaixo da demanda mundial por papel, daí sua boa valorização atual. No entanto, esse quadro pode se reverter em algum momento, assim que as reservas internacionais, principalmente as dos países nórdicos, voltarem a se estabilizar.

Esse é o maior risco que a especialização produtiva do território pode trazer para as regiões e lugares onde se instala, especialmente quando se trata de commodities internacionais e monoculturas, onde o risco da volatilidade dos mercados e da vulnerabilidade a eventuais mudanças climáticas e pragas é uma certeza. Os agricultores fomentados que assinaram contrato com as empresas, por exemplo, vendem sua madeira às fábricas pelo preço vigente no período do corte, e não do plantio, realizado, no mínimo, com sete anos de intervalo.

\footnotetext{
${ }^{22}$ Estudo da FGV, publicados no caderno Dinheiro, do jornal Folha de São Paulo, de 01/08/06.
} 


\title{
Capítulo 3
}

\section{A empresa Veracel e a especialização produtiva do território no extremo sul da Bahia - aprofundando contradições}

\begin{abstract}
... Agora eu quero contar as histórias da beira do cais da Bahia. Os velhos marinheiros que remendam velas, os mestres de saveiros, os pretos tatuados, os malandros sabem essas histórias e essas canções. Eu as ouvi nas noites de lua no cais do mercado, nas feiras, nos pequenos portos do Recôncavo, junto aos enormes navios suecos nas pontes de Ilhéus. O povo de Iemanjá tem muito que contar.
\end{abstract}

(Trecho inicial do romance Mar Morto, de Jorge Amado) 


\section{1) Mudanças na organização do espaço regional e os principais fatores} de atração para o circuito espacial produtivo de celulose

O sul da Bahia conheceu, há pouco mais de um século, um intenso processo de modernização, trazido pela monocultura do cacau, que afinal também foi fruto de uma especialização produtiva calcada em uma commodity internacional. Essa produção, que chegou a abranger cerca de oitenta municípios do sul da Bahia, fez com que a região perdesse seu caráter de "sertão úmido", onde predominavam as lavouras de subsistência e as culturas incipientes do açúcar, do fumo e do algodão, para abrigar uma produção que chegou a representar, sozinha, $28 \%$ da receita da balança comercial do país, sendo o terceiro maior produto de exportação, na década de 40 . Há que se levar em conta que esta experiência de crescimento econômico era, até então, inédita para esta porção do território brasileiro, pois, o desenvolvimento do extremo sul baiano é considerado tardio, quando comparado ao restante do estado da Bahia e do Nordeste do país.

A dinâmica territorial desta região, segundo Fanzeres (2005), acabou por estabelecer três diferentes zonas de ocupação, associadas aos ciclos econômicos que desenvolveram a área. A primeira a ser ocupada foi a Zona Litorânea, que, com atividades de pesca, agricultura de subsistência e comércio incipiente, abastecia a região do Recôncavo baiano. $O$ acesso pelo mar era então o principal meio de comunicação entre as vilas e povoados, que se assentavam sobre a pequena agricultura familiar. Nesse período, os rios da região desempenharam um papel importante na interligação com a chamada Zona Central, região por onde hoje passa a BR - 101 e se concentram os municípios mais populosos do extremo sul: Teixeira de Freitas, Eunápolis e Itamaraju. Na Zona Central, a ocupação humana se iniciou ao longo dos rios que cortam a região, e se intensificou, no início do século passado, com a construção da ferrovia que ligava a Bahia a Minas Gerais, escoando a produção de cacau e integrando o interior do extremo sul com as rotas marítimas que usavam o porto de Caravelas - BA (na época, o maior entreposto da região). E a terceira região, a Zona Oeste, abriga as vilas e municípios próximos da divisa com o estado de Minas Gerais, historicamente menos povoados e desenvolvidos. O mapa a seguir nos mostra a localização 
das principais cidades do extremo sul baiano, situadas tanto na costa como na chamada Zona Central.

\section{Mapa 5 - Extremo sul da Bahia e suas principais cidades}

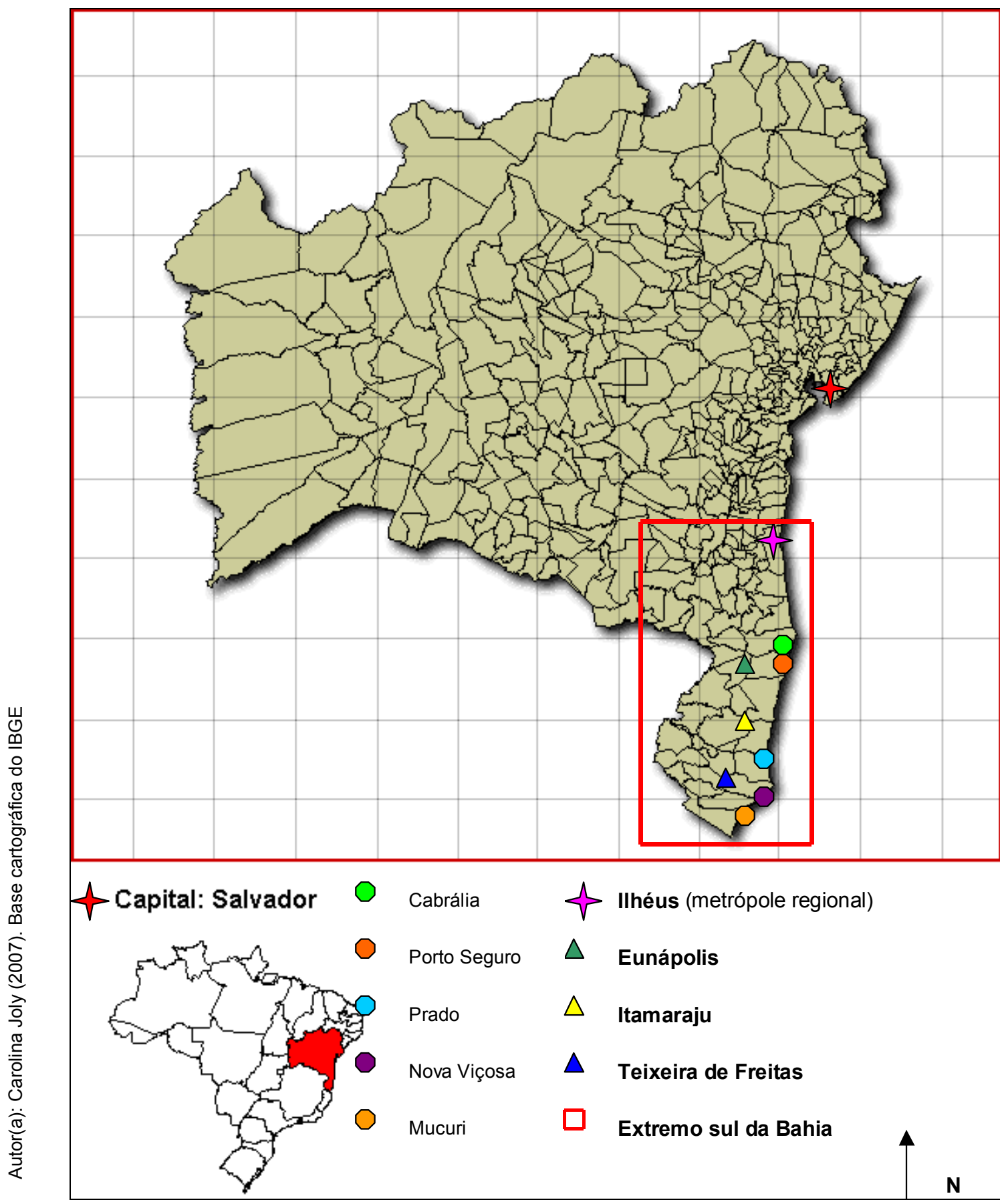

O território do extremo sul foi recebendo, aos poucos, os objetos técnicos e os primeiros sistemas de engenharia, como a ferrovia e a interligação com o porto, fazendo acelerar atividades econômicas como a 
extração madeireira, muito forte na região desde as primeiras ocupações, e induzindo, com a abertura dos pastos, a expansão da pecuária bovina. $O$ processo de crescimento e ocupação do extremo sul baiano teve seu momento de inflexão a partir dos anos 50, quando ocorreu a expansão da cultura cacaueira, e secundariamente, também da pecuária e da exploração de madeira das florestas nativas.

O sistema de normas também induziu o desenvolvimento dessa região do país, direcionando-o para a produção do cacau. Após a criação do ICB (Instituto de Cacau da Bahia), ainda em 1931, pelo governo estadual e da CEPLAC (Comissão Executiva do Plano de Recuperação Econômico-Rural da Lavoura Cacaueira) em 1957, pelo governo federal, estabeleceu-se uma taxa, cobrada sobre as exportações de cacau, a fim de custear os investimentos em infra-estrutura para a região produtora, que recebia um intenso fluxo migratório. Assim, além dos sistemas de circulação, investiu-se também na infra-estrutura urbana (escolas, postos de saúde, saneamento, eletrificação rural, usinas hidrelétricas) dos principais centros produtores regionais, como Ilhéus, Itabuna e Porto Seguro. Também se investiu em qualificação da mão-de-obra local, criando a Escola Média de Agricultura da Região Cacaueira (EMARC). (Garcez e de Freitas, 1979).

Além disso, a produção da monocultura do cacau deixou como herança territorial as primeiras redes técnicas e infra-estruturas de circulação do sul da Bahia. Essa porção do estado foi, aos poucos, sendo recortada por ferrovias, rodovias, portos, e aeroportos, como os de llhéus, em função da produção de cacau, destinada quase que exclusivamente à exportação.

Como a zona produtora se estivesse expandido, sem que o traçado ferroviário acompanhasse essa expansão, a iniciativa particular e dos poderes públicos, seguida de um arrojado plano do Instituto do Cacau dotou a região de uma boa rede viária, que corta a zona cacaueira em todas as direções. (Santos, 1957:67).

Contudo, o período de grande transformação da organização espacial do extremo sul baiano ocorreu na década de 70, durante a construção da rodovia BR-101 (Rodovia Governador Mário Covas). Com a abertura do trecho de interligação entre Vitória-ES e Salvador-BA, iniciou-se um novo ciclo madeireiro no extremo sul, com a participação de empresários vindos, principalmente, do Espírito Santo, incluindo o grupo Aracruz, que comprou 
terras e extraiu madeira na região. Seguindo o rastro do desmatamento, a pecuária também ganhou novo fôlego e ganhou o espaço do cacau na Zona Central, que acabou migrando para o interior (Zona Oeste). É importante lembrar que a pecuária, assim como a extração de madeira, se caracterizou pela manutenção da concentração fundiária na região, com mais de $60 \%$ dos estabelecimentos abrigando áreas acima de quinhentos hectares (Fanzeres, 2005). Nesse período, os dois principais acampamentos do então Departamento Nacional de Estradas de Rodagem (DNER) deram origem aos atuais maiores centros urbanos regionais: Teixeira de Freitas e Eunápolis.

Muito dessa herança territorial, com exceção da BR-101, no entanto, já não existe mais, pois as ferrovias, alguns portos e caminhos, abertos para escoar a produção do cacau, hoje estão desativados, e a estagnação econômica trazida pelo colapso da monocultura cacaueira, levou muitos municípios produtores de volta à recessão, desde fins da década de 80 . Segundo dados da CEPLAC, a produção brasileira de cacau registrou uma grande redução no volume de produção entre os anos de 1990 e 1999, caindo de 356.327 toneladas (safra de 1990 e 1991) para 98.617 toneladas (safra 1999 e 2000), uma redução de cerca de $72 \%$.

Mas ficou impressa no território baiano a marca da principal herança que a "era do cacau" deixou, a integração territorial, seja com o restante do país, através das estruturas de circulação que permaneceram, como a então rodovia BA - 2 (que ligava Salvador-BA à Vitória-ES) que hoje é parte da BR - 101, seja através da consolidação de uma rede de relações na própria região, que levou à integração irreversível entre o "interior" e o litoral do sul da Bahia, potencializando os futuros usos dessa porção do território.

O turismo surgiu, em meados da década de 80 , como uma das principais alternativas, especialmente para os municípios da Zona Litorânea do extremo sul baiano, como Porto Seguro e Santa Cruz de Cabrália, e em menor volume, para Mucuri, Prado e Nova Viçosa. Contudo, essa atividade econômica não foi capaz de absorver toda a mão-de-obra proveniente do êxodo rural, provocado pelo colapso da lavoura cacaueira. As cidades sofreram com o aparecimento de favelas e o comprometimento das já precárias redes públicas de saúde, educação, transporte e saneamento. Este é um processo que continua a ocorrer, com a chegada contínua dos "caatingueiros", como são chamados os 
migrantes do interior da Bahia e do sertão de Minas Gerais que continuam chegando à região de Porto Seguro.

Em 1988, Eunápolis, então distrito do município de Porto Seguro, se emancipa e ganha autonomia. Em pouco tempo, a nova cidade, localizada à beira da BR -101, se tornou um dos principais entrepostos comerciais do extremo sul baiano, hoje com uma população de cerca de noventa mil habitantes, oferecendo serviços especializados de saúde, comércio atacadista que abastece a rede hoteleira de Porto Seguro, e tem a segunda maior praça financeira da região (possui quatro agências bancárias), perdendo apenas para o município de Teixeira de Freitas, mais ao sul do estado. Além do comércio e dos serviços, Eunápolis, assim como toda a região, também se destacou, até a década de 90, pela produção agrícola de frutas, especialmente o mamão, além da produção de café, da pecuária bovina de corte e das atividades derivadas da extração de madeira das matas nativas (produção de lenha, carvão, caixetaria, pallets e venda de madeira de lei) também reforçaram a economia local.

Em 1991, a então Veracruz Florestal Ltda., subsidiária da empresa baiana Odebrecht S.A., realizou as primeiras aquisições de terra em Eunápolis e, em seguida, deu início ao plantio de eucaliptos. Em 1996, a empresa obteve a licença ambiental para construção da fábrica de celulose, gerando expectativa de desenvolvimento para o município e atraindo mais migrantes. Nesse período teve início o processo inflacionário do preço da terra na região, mencionado anteriormente.

Além da importância de Eunápolis na hierarquia regional, do forte incentivo político ao investimento Veracel, das estruturas de circulação consolidadas, da rede de serviços disponíveis e da tradição em atividades madeireiras, outros aspectos, também podem ter atraído a empresa produtora de celulose para Eunápolis, dentre elas as condições biogeográficas desta porção do território baiano, que, segundo a empresa, são ideais para o cultivo de eucaliptos (assim como o norte do Espírito Santo, que possui a mesma formação geomorfológica). Fatores como o clima (quente e úmido, com chuvas bem distribuídas durante o ano), a alta incidência de luz solar, o solo profundo e a topografia predominantemente plana, fazem do sul da Bahia uma das melhores localizações do planeta para o cultivo do eucalipto, segundo a 
Veracel. As plantas ali cultivadas chegam a crescer em ritmo até dez vezes mais rápido do que em alguns países europeus.

O aspecto logístico da localização do empreendimento, aliado às heranças da fluidez territorial rodoviária, deixadas pela cultura do cacau, também se transformou em uma importante vantagem locacional para a empresa. O território do sul da Bahia se mostra ideal para a instalação de empresas que têm sua produção voltada para a exportação, pois as distâncias médias entre o "interior" e a faixa litorânea são de apenas setenta quilômetros. A costa, pouco recortada, facilita a instalação de terminais portuários exclusivos mais perto das áreas produtoras, pois o porto mais próximo, em Ilhéus-BA, fica a cerca de duzentos quilômetros de distância. Em 2002, por exemplo, entrou em operação o terminal marítimo construído pela Veracel, instalado no município de Belmonte. Inicialmente usado para o transporte de madeira, hoje é local de embarque das barcaças da celulose produzida pela Veracel, com destino ao Portocel, em Barra do Riacho-ES, de onde é exportada. A foto a seguir ilustra o funcionamento do terminal.

Esses novos objetos técnicos, como o terminal, quando anexados ao território trazem para o lugar a nova divisão territorial do trabalho, calcada na especialização da produção.

Graças aos progressos da ciência e da técnica e à circulação acelerada de informações, geram-se as condições materiais e imateriais para aumentar a especialização do trabalho nos lugares. Cada ponto do território modernizado é chamado a oferecer aptidões específicas à produção. É uma nova divisão territorial fundada na ocupação de áreas até então periféricas e na remodelação de regiões já ocupadas. (Santos e Silveira, 2001:105). 


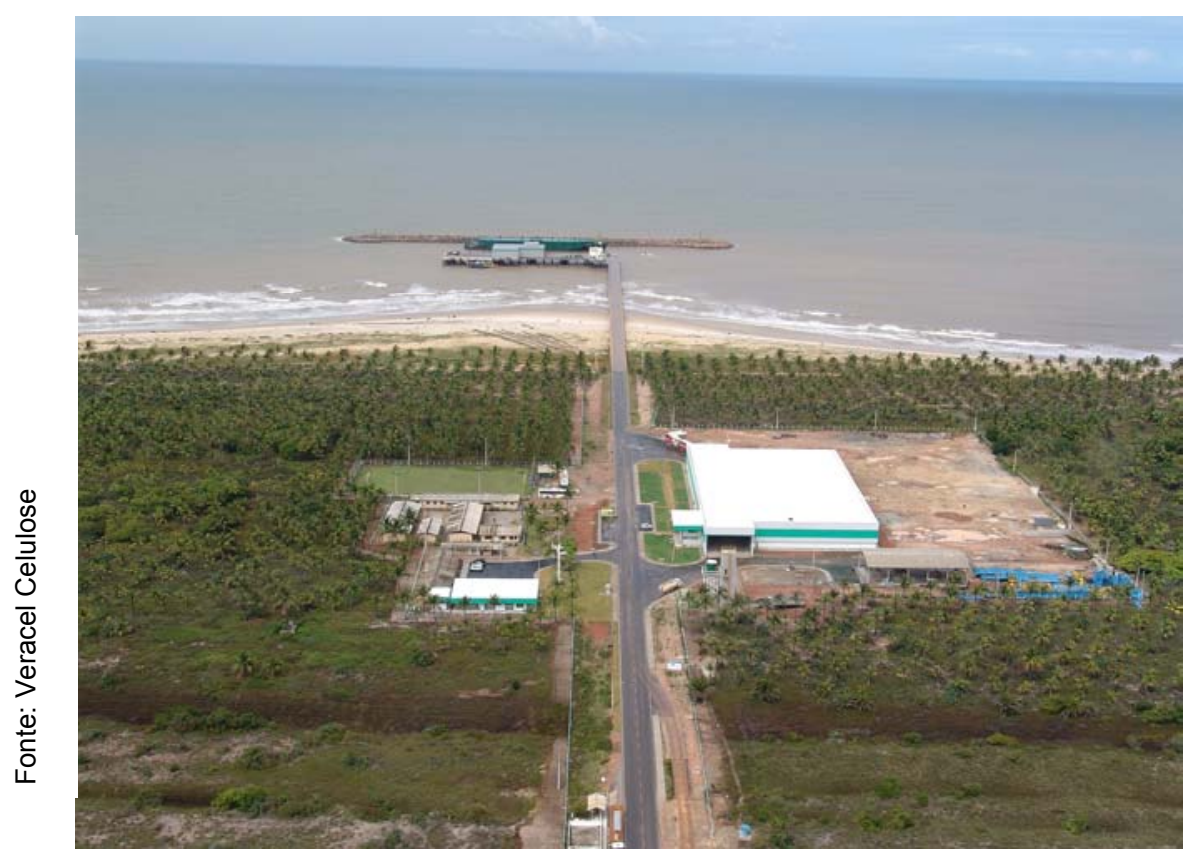

Figura 7 - Vista aérea do terminal marítimo de Belmonte-BA, mantido pela Veracel.

Contudo, um dos principais fatores de atração de empresas, especialmente quando se trata de grandes investimentos como os da Veracel, consiste em estabelecer políticas públicas de incentivo e atração. O governo estadual da Bahia também tem criado, através de seus Planos Pluri-Anuais (PPAs), iniciados na década de 90, uma série de diretrizes que buscam atrair investimentos para o estado. Ao adotar uma política de desconcentração dos investimentos, em geral aglutinados na Região Metropolitana de Salvador (RMS), o governo aposta na estratégia de irradiação dos "pólos de desenvolvimento", a serem instalados em outras regiões do território baiano. Segundo Armando Avena Filho, Secretário de Planejamento estadual, da gestão do governador Paulo Souto (entre 2003 e 2006),

Algumas áreas urbanas do interior estão se consolidando como pólos regionais e oferecendo oportunidades de negócios que o espaço altamente competitivo da RMS nem sempre oferece. É o caso, por exemplo, de Juazeiro, Barreiras, Vitória da Conquista, Eunápolis, Teixeira de Freitas, Porto Seguro, Ribeira do Pombal, Itapetinga, Ilhéus/Itabuna, Jequié e outros. ${ }^{23}$

O governo criou também programas especiais para auxiliar na implementação desta estratégia, como o "Programa Cidades Líderes" (PPA, 2000 - 2003:10), com a missão de promover a interiorização do desenvolvimento nas vinte e cinco maiores cidades do estado (excluindo os

\footnotetext{
${ }^{23}$ Em entrevista, publicada na Revista Cerrado Rural Agronegócios, Dez. de 2005.
} 
municípios da Região Metropolitana de Salvador), em núcleos urbanos de porte médio e de localização estratégica. A cidade de Eunápolis, sede da Veracel, foi uma das escolhidas pelo programa.

Além desses programas especiais, o governo do Estado da Bahia, em seu planejamento realizado na década de 90, designou diferentes áreas do estado para produções específicas, como a soja na região de Barreiras, as frutas tropicais no Vale do Rio São Francisco e o reflorestamento no extremo sul do estado, elegendo os principais eixos de desenvolvimento. Essa visão compartimentada demonstra um tipo de planejamento que enxerga o território apenas a partir de pontos e corredores de circulação, ou seja, fluidez para os circuitos produtivos, enquanto as outras demandas sociais dos baianos são colocadas em segundo plano. Ao contrário da diminuição das disparidades dentro do estado, como é afirmado no PPA (Plano Pluiri-anual 2003 -2006), essa nova ordem de integração competitiva concorre, definitivamente, para o aprofundamento das desigualdades regionais, há tempos presente no território da Bahia.

O governo baiano, então, incentivou a instalação do "polo produtivo de papel e celulose" (PPA, 2000 - 2003:162) na região denominada "Costa do Descobrimento", onde se localiza Eunápolis, estabelecendo parceria com as empresas e com os municípios, e destacando o investimento da Veracel como um dos carros-chefe do desenvolvimento baiano, na época ainda em implantação:

O dinamismo da economia baiana também pode ser avaliado pelos investimentos de $\mathrm{R} \$ 20,8$ bilhões, em parceria com a iniciativa privada, os municípios e o Governo Federal. Avultam-se alguns projetos, (...) em indústrias como a Ford, Montsanto, Veracel e Petrobrás. (PPA, 20002003:6).

Outros dois fatores, no entanto, também concorreram para que as empresas envolvidas no empreendimento da Veracel escolhessem a região de Eunápolis e o estado da Bahia para concretizá-lo. No que tange a rigidez dos órgãos ambientais deste estado, por exemplo, sabe-se que é bem menos severa que a fiscalização e os licenciamentos em outros estados, onde a contestação e a vigilância, até da sociedade, é maior. E o outro fator é propriamente a dificuldade que a população dessa região enfrenta para se organizar coletivamente, seja em associações, sindicatos ou ONG's, devido ao despreparo (pouca escolaridade) e à falta de tradição em reivindicar direitos ou 
denunciar abusos, pois essa é uma região que ainda tem forte na memória as lembranças do coronelismo. Como podemos observar na tabela abaixo, os índices de escolaridade de Eunápolis e de Itabepi (município mais pobre sob influência dos plantios da Veracel), são alarmantes.

Tabela 1 - Analfabetismo funcional por faixa etária da população (2000)

\begin{tabular}{|c|c|c|}
\hline \multicolumn{2}{|c|}{ Eunápolis } & Itabepi \\
\hline 10 a 14 anos, com menos de 4 anos de estudo (\%): & 44,92 & 76,38 \\
15 a 17 anos com menos de 4 anos de estudo (\%): & 17,54 & 44,47 \\
18 a 24 anos, com menos de 4 anos de estudo (\%): & 22,34 & 47,11 \\
\hline 25 anos ou mais com menos de 4 anos de estudo (\%): & 39,21 & 61,69 \\
\hline
\end{tabular}

Fonte: IBGE

Como se pode concluir, empreendimentos desse porte, como a Veracel, escolhem com precisão aonde vão se implantar e dificilmente se concretizam sem o apoio, seja ele direto ou indireto, do Estado. Por mais que este tenha tido seu papel enfraquecido, por conta das ideologias privatizadoras atuais, ainda é o poder público quem legitima as decisões e intervenções territoriais. Cabe ao Estado preparar o território para a chegada das empresas, provendo as infra-estruturas técnicas, principalmente aquelas ligadas à circulação, para então se tornar uma "região ganhadora", no contexto ensejado pela globalização, de competitividade entre os lugares e de fortalecimento do poder hegemônico das grandes empresas frente ao Estado, que agora legitima um planejamento territorial balizado por estratégias de mercado.

Para Cataia (2003), este é um exemplo de "alienação do território". Segundo o autor,

Este diz respeito aos lugares que preparam seu território com todo um conjunto de obras de infra-estrutura e isenções fiscais no intuito de atrair investimentos, mas acabam por se transformar em reféns da política das empresas em função do poder econômico que as empresas transnacionais possuem. (Cataia, 2003:402)

A primazia da circulação é a face que melhor ilustra esse novo planejamento territorial, valendo-se dos atuais sistemas de engenharia (ligados aos transportes e à comunicação) para fazer uso dos territórios com maior eficiência e precisão. 
Se outrora havia a necessidade de implantar sistemas de objetos que assegurassem a produção e, por conseguinte, seu escoamento para o estrangeiro, hoje os sistemas de engenharia devem garantir primeiro a circulação fluida dos produtos, para possibilitar a produção em escala comercial. É a circulação em sentido amplo, que viabiliza a criação e a continuidade das áreas de produção. (...) As firmas desenham suas novas topologias fundadas em suportes territoriais como estradas, ferrovias, hidrovias, portos e aeroportos, (...). (Santos e Silveira, 2001:64).

Neste contexto, entretanto, as desigualdades se aprofundam, assim como a fragmentação do território, que hoje responde mais aos humores do mercado internacional do que aos apelos da população local.

Atraída especialmente por esse ambiente institucional propício, criado pela atmosfera dessa lógica adotada pelo planejamento estatal, a Veracel implementa, no extremo sul da Bahia, a especialização produtiva dessa área. Toda a dinâmica territorial de fluxos e as redes de relações entre os municípios sob influência direta dessa empresa foram rearranjados em função dessa especialização.

Mais do que isso, essa especialização impregnou as localidades produtoras, como Eunápolis, por exemplo, de uma expressiva densidade técnica, informacional e organizacional, conferindo um novo status ao município, dada a envergadura do projeto da Veracel. A cidade de Eunápolis passou a abrigar atividades intensivas em tecnologia, até então inéditas no lugar, que vão desde as técnicas e materiais empregados na construção da fábrica até as formas de plantio, manejo e monitoramento das áreas cultivadas, para uso exclusivo da empresa.

Cabe ressaltar, porém, que a especialização produtiva de Eunápolis em torno das atividades de silvicultura comandadas pela Veracel, não caracterizam um quadro de especialização extrema, como o caso das 'cidades-empresa'ou company towns brasileiras, estudadas por Piquet (1998). Na década de 80, a própria Aracruz Celulose chegou a implantar um bairro residencial, no município de Aracruz - ES, para abrigar seus funcionários. Segundo a autora, a empresa tomou esta decisão principalmente pela ausência, na época, de ligação rodoviária em boas condições que interligasse a região à capital, Vitória-ES, a cerca de cento e vinte quilômetros de distância, dificultando o deslocamento diário dos funcionários e executivos da Aracruz. No caso da Veracel, a empresa preferiu investir no oferecimento de transporte diário aos seus funcionários e 
executivos, que fixaram residência em Porto Seguro-BA, a cerca de oitenta quilômetros da fábrica.

Mas todo esse acúmulo tecnológico e informacional, no entanto, não é visível na paisagem do município de Eunápolis. A densidade técnica e organizacional, promovida pela especialização produtiva, está altamente concentrada no sítio da fábrica. No seu entorno imediato é notório o contraste com a paisagem local, marcada pela presença de objetos técnicos que parecem ter parado no tempo, como casas de taipa e carroças. A foto abaixo ilustra a zona rural de Eunápolis.

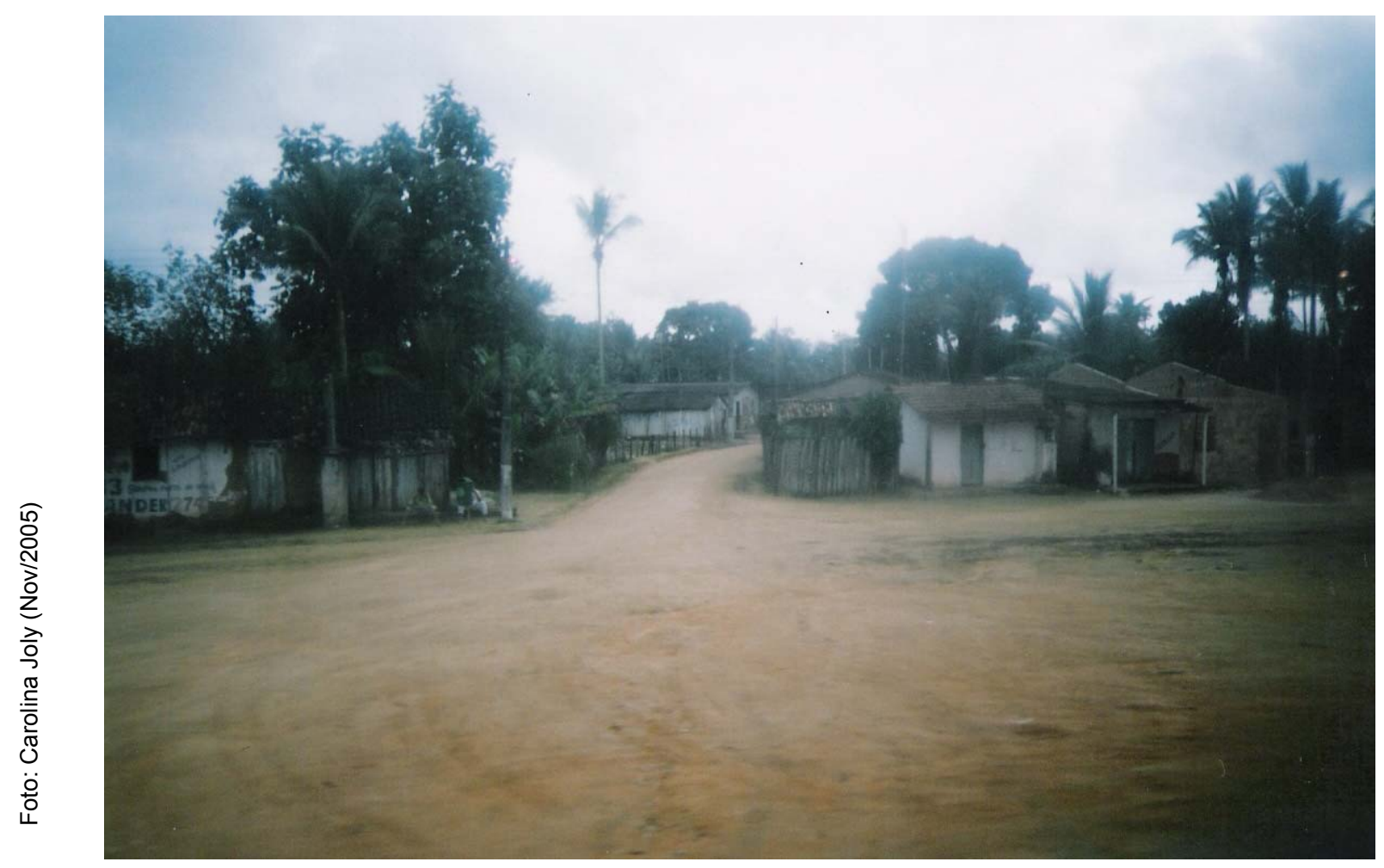

Figura 8 - Zona rural de Eunápolis.

Essa concentração extremamente pontual das modernizações, inseridas no território pelas especializações produtivas denotam, a um só tempo, o grau de intencionalidade das escolhas dos lugares de abrigo dessas modernizações e dos agentes aptos a fazerem uso delas.

A densidade informacional nos indica o grau de exterioridade do lugar e a realização de sua propensão a entrar em relação com outros lugares, privilegiando setores e atores. A informação unívoca, obediente às regras de um ator hegemônico, introduz, no espaço, uma intervenção vertical, que geralmente ignora o seu entorno, pondo-se ao serviço de quem tem os bastões de comando. (Santos, 1999:17) 
A doze quilômetros da fábrica, por exemplo, localiza-se o distrito de Barrolândia, que hoje abriga, além da pobreza, o maior foco de hanseníase do país. Caracterize-se assim, um franco processo de diferenciação espacial, de precisão quase cirúrgica, movido pela extrema especialização produtiva do território e alimentando a sua fragmentação.

\section{2) Política territorial da empresa Veracel}

\section{Histórico de implantação da empresa}

Em 1991, a empresa subsidiária da Odebrecht S/A., a Veracruz Florestal Ltda., incentivada pelo plano do governo da Bahia de destinar o extremo sul do estado para atividades de reflorestamento, adquire as terras, em Eunápolis e na região. Em seguida, dá início ao plantio de eucaliptos, realizando experimentos para a escolha de espécies adequadas às condições edafoclimáticas da região. Em 1996, a empresa obtém a licença ambiental para a construção da fábrica de celulose. Nesse período, a empresa Aracruz Celulose já possuía terras na região de Eunápolis e a Bahia Sul Suzano entrava em operação em Teixeira de Freitas.

Em 1997, a Odebrecht encontra uma multinacional interessada em estabelecer uma parceria para o investimento na fábrica, e então se associa à Stora Enso, multinacional sueco-finlandesa líder mundial na fabricação de papel. Em 1998, as parceiras recebem uma proposta da Aracruz Celulose para esta se juntar à sociedade e decidem mudar a razão social da joint-venture para Veracel Celulose S/A. No entanto, no ano de 2000, a Odebrecht desiste da sua participação, e permite que a Aracruz, assim como a Stora Enso, fique com $50 \%$ das ações.

No ano de 2001, se iniciam as operações de colheita florestal, onde parte da produção é vendida para abastecer as serrarias e carvoarias locais (vendendo a madeira imprópria para a fabricação de celulose), e a outra parte é transportada para a fábrica de celulose da Aracruz, no Espírito Santo. Esse transporte era feito, inicialmente, por rodovias, mas depois da construção do terminal marítimo da Veracel, localizado no município de Belmonte, a madeira 
passou a ser transportada por barcaças até o porto exclusivo da Aracruz (o Portocel), em Barra do Riacho - ES.

Em 2003, iniciam as obras de terraplanagem do terreno da fábrica. No ano seguinte, o financiamento do BNDES é aprovado e a construção da fábrica é iniciada. Em 2005, a empresa obteve as certificações ISO14001 e CERFLOR, a fábrica foi concluída e, no segundo semestre deste mesmo ano, entrou em operação industrial pela primeira vez.

\section{Área de influência da empresa e seus números}

O empreendimento da Veracel está disperso por dez municípios na região de Eunápolis, abrangendo uma população de cerca de trezentos e noventa mil habitantes. Somente o município de Eunápolis, abriga cerca de noventa mil habitantes ${ }^{1}$. Os municípios envolvidos são: Eunápolis, Porto Seguro, Santa Cruz de Cabrália, Belmonte, Canavieiras, Itabela, Itagimirim, Itabepi, Guaratinga e Mascote.

Com exceção de Eunápolis, que por ser o centro regional, tem como atividades econômicas predominantes o comércio e a prestação de serviços, e de Porto Seguro, fortemente voltada para o turismo, os demais municípios são essencialmente direcionados para produção agrícola (em geral, de frutas tropicais como mamão, abacaxi e coco da bahia, além de cacau, dendê e café), pecuária de corte e pesca. Em alguns desses municípios, como Mascote, Itabela Itagimirim e Itabepi, a principal fonte de receita dos habitantes provém do funcionalismo público municipal, entre salários e aposentadorias. Itabepi também recebe royalties por abrigar a usina geradora de energia elétrica da região. O mapa abaixo mostra a localização desses municípios.

\footnotetext{
${ }^{1}$ Fonte: IBGE (2004).
} 


\section{Mapa 6 - Municípios sob influência da Veracel Celulose}

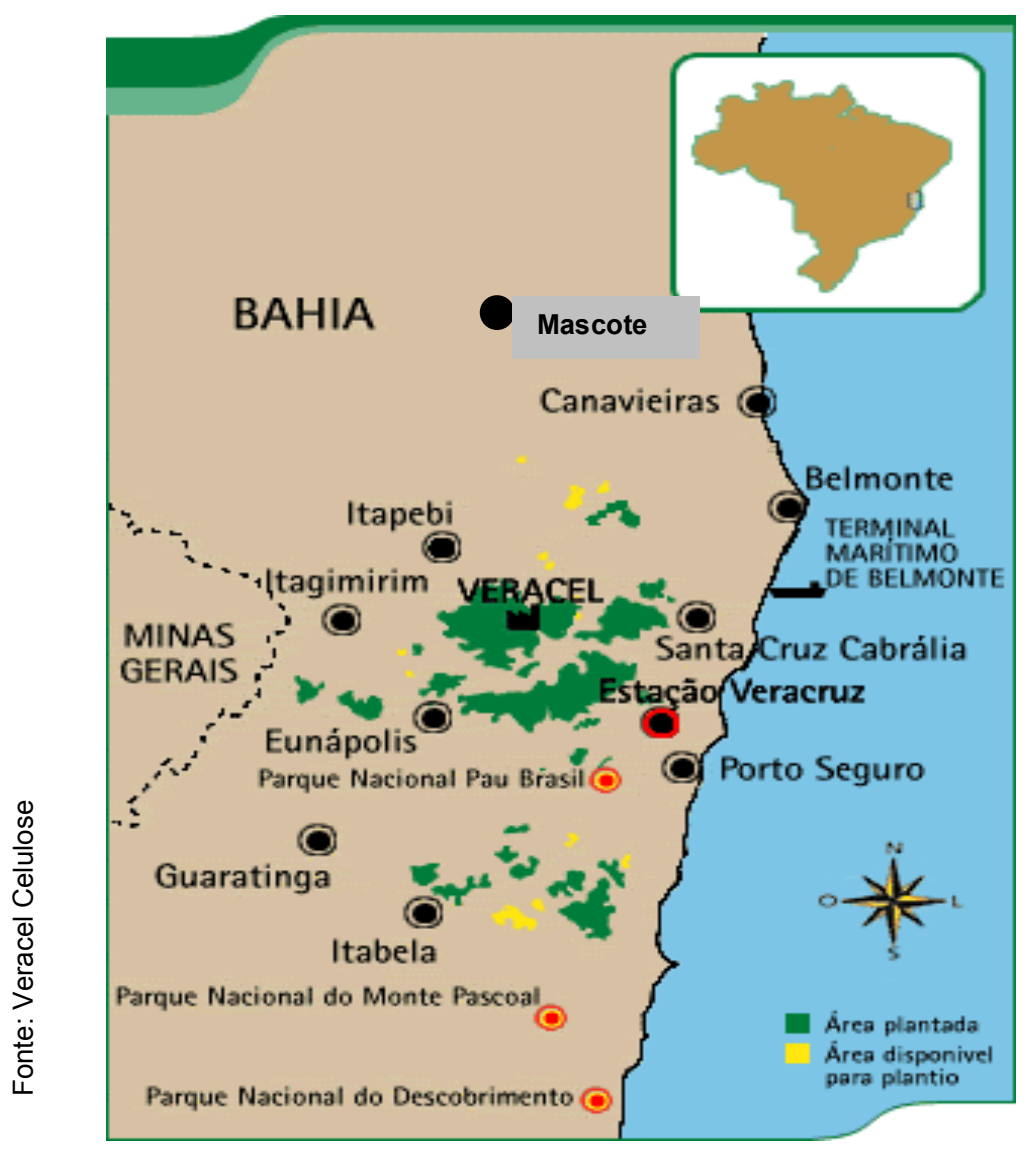

A Veracel é hoje a segunda maior empregadora de Eunápolis, atrás apenas do serviço público, e é a principal fonte de receita tributária do município que, através do recolhimento do Imposto sobre Serviços de Qualquer Natureza $\left(\right.$ ISSQN ${ }^{24}$, sobretudo desde 2005, quando o prefeito atual do município revogou o desconto dado anteriormente à empresa (aumentando de $2 \%$ para $5 \%$ ), reforça os laços da especialização produtiva sobre o lugar. É importante lembrar que o índice fixado pela prefeitura vale para todos os estabelecimentos prestadores de serviços, comerciais e industriais do município, que sofreram com o aumento do tributo.

Localizada na zona rural de Eunápolis, a fábrica da Veracel ocupa uma área de dois milhões de metros quadrados, sendo quatrocentos mil de área construída (ver planta da fábrica, ainda em construção, na próxima página). O

\footnotetext{
${ }^{24}$ Antigo Imposto sobre Serviços (ISS). As prefeituras devem estabelecer a cobrança desse imposto nos valores entre $2 \%$ e $5 \%$ do faturamento dos estabelecimentos, devidamente registrados dentro de seus perímetros municipais.
} 
local do sítio da fábrica fica a cerca de cinqüenta e cinco quilômetros do centro de Eunápolis. A empresa possui hoje uma área de 165 mil hectares de floresta, espalhada em fragmentos dispersos por esses municípios. A área destinada ao plantio de eucalipto corresponde a 78,1 mil hectares (47,5\% da área total), à área de reserva legal e de preservação ambiental corresponde a 79 mil hectares (48\%), e as áreas destinadas às infra-estruturas (estradas, acessos) completam 7,5 mil hectares $(4,5 \%)$. As fotos abaixo ilustram as áreas de plantio e a fábrica da empresa.

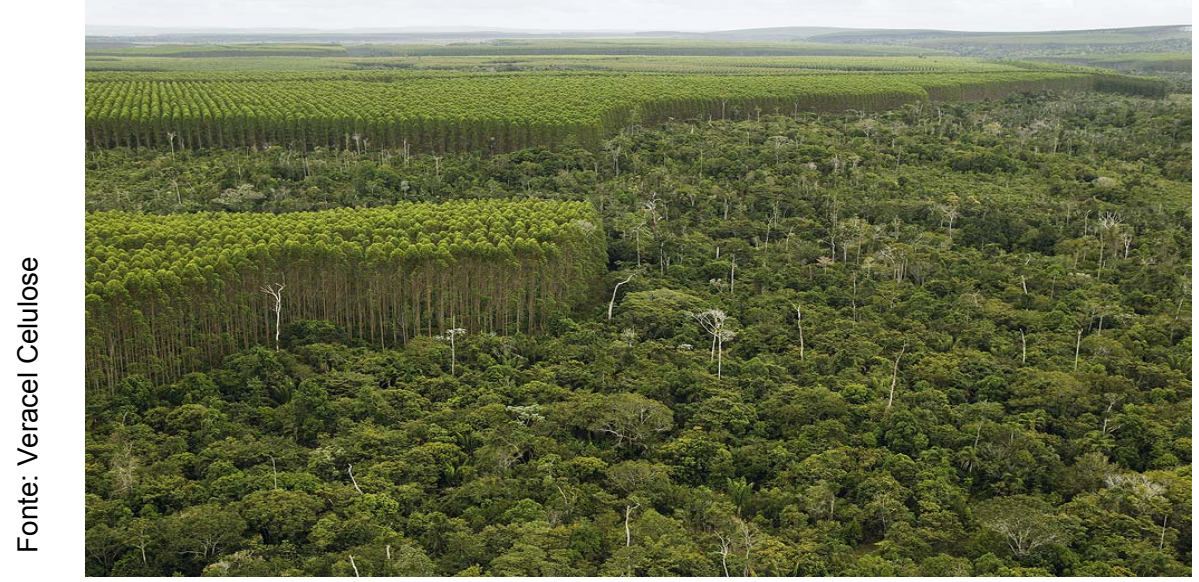

Figura 9 - Vista aérea de uma área de plantio junto da área de preservação.

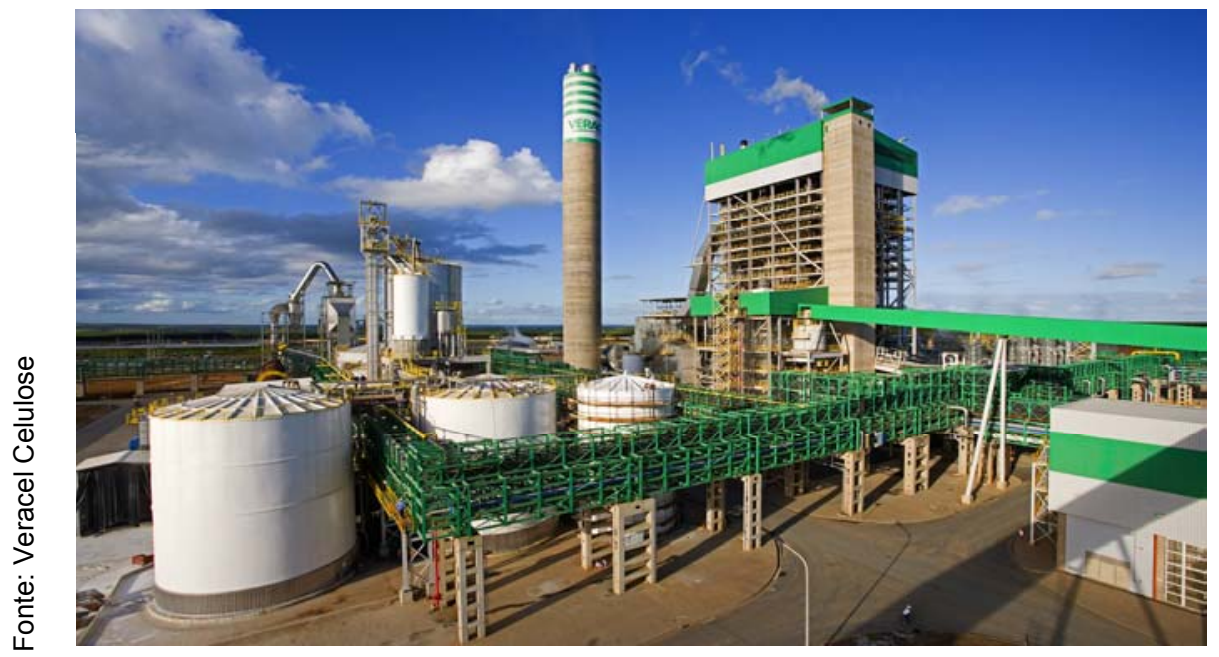

Figura 10 - Fábrica da Veracel 


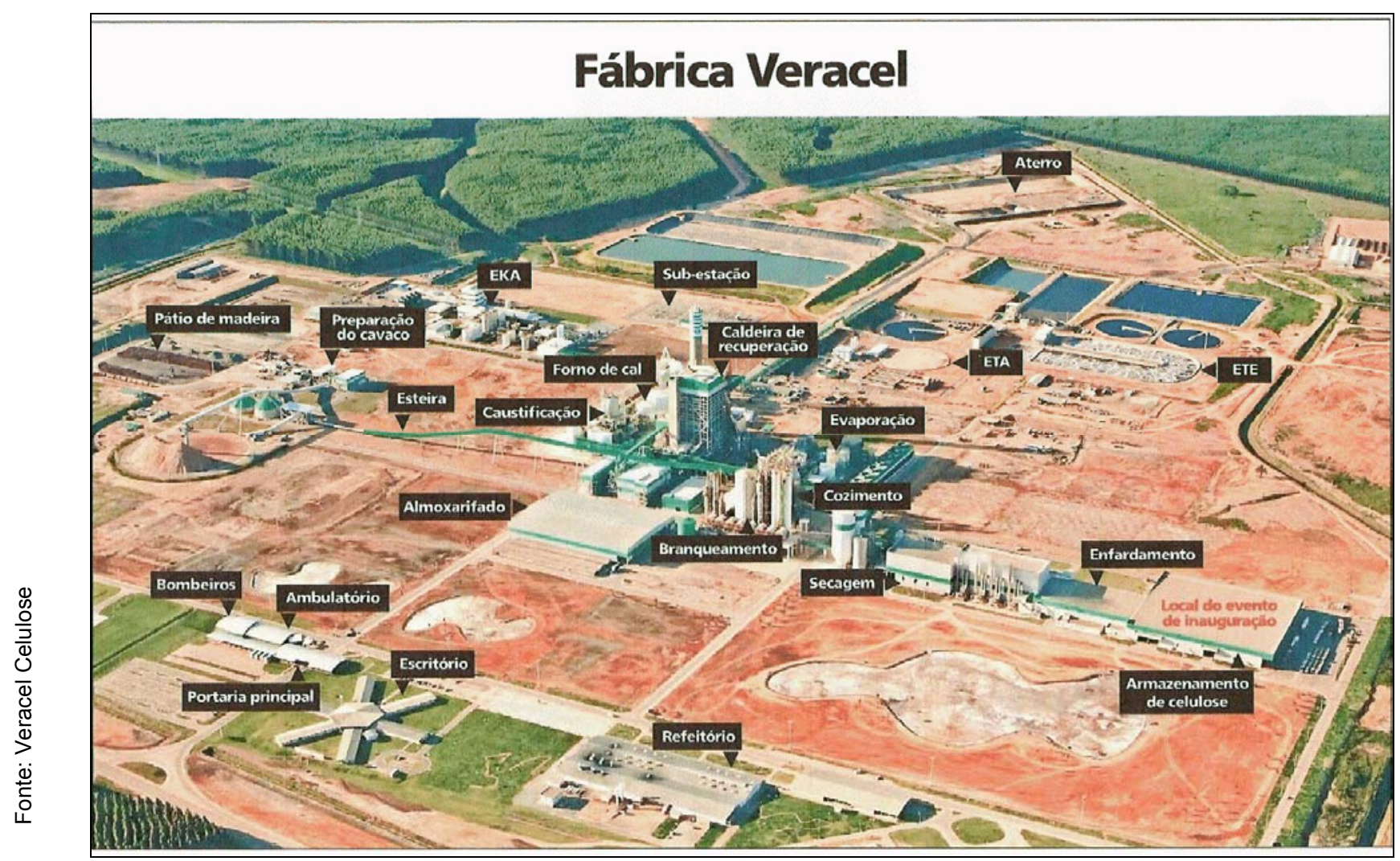

Figura 11 - Sítio da fábrica, ainda em fase de construção.

$\mathrm{Na}$ área destinada à preservação ambiental, está inclusa uma das maiores reservas particulares de patrimônio natural (RPPN) do país, com cerca de seis mil hectares, situada entre Eunápolis e Porto Seguro, denominada Estação Veracruz. Esta é, atualmente, a maior reserva particular de Mata Atlântica do país, correspondendo a $18 \%$ da área de proteção ambiental, sob propriedade particular, de todo o estado da Bahia. A Estação Veracruz constitui um dos últimos remanescentes de floresta primária do sul da Bahia, com alto índice de biodiversidade, abrigando muitas espécies endêmicas sob risco de extinção. A área faz parte do chamado Corredor Central da Mata Atlântica, que compreende as unidades de conservação deste bioma que se estendem desde a região do centro-norte do Espírito Santo e percorrem todo o sul da Bahia. Aberta para a visitação pública, a Estação recebe cerca de dois mil visitantes por ano.

A manutenção de uma área particular de dimensões tão expressivas contribui positivamente para a imagem pública da empresa Veracel, que, no entanto, é obrigada legalmente a criar e manter uma unidade de conservação. Segundo Lei $n^{\circ} 9.985$ (18/07/00), em seu artigo 36, nos casos de licenciamento 
ambiental de empreendimentos de significativo impacto ambiental, como no caso da Veracel, o empreendedor é obrigado a manter uma unidade de conservação de proteção integral, cujo montante não poderá ser menor do que $0,5 \%$ dos custos totais do empreendimento ${ }^{25}$.

Quanto à área destinada ao plantio de eucalipto, a Veracel ainda dispõe das plantações contabilizadas pelo programa de fomento florestal, oferecido pela empresa. É um sistema de parceria, onde o fazendeiro, desde que obedeça aos pré-requisitos do contrato (é preciso ter mais de cinqüenta hectares e a uma distância máxima de cento e cinqüenta quilômetros da fábrica, por exemplo), oferece suas terras e a empresa oferta toda a assistência técnica e o plano de manejo necessário, desde o plantio até a colheita (equivalente a um período de sete anos, em média). No contrato, consta que o fazendeiro receberá um "aluguel" anual pelas terras e que, depois da colheita, deve vender a madeira para a Veracel, pelo preço vigente no mercado no momento do corte, geralmente aferido pela empresa. O programa de fomento está implantado nos municípios de Eunápolis, Santa Cruz de Cabrália, Belmonte, Itagimirim, Itabepi, Guaratinga, Porto Seguro e Mascote, totalizando cerca de trinta mil hectares.

É dessa forma que a Veracel pretende ampliar a cobertura vegetal de eucalipto na região, sem comprar mais um hectare de terra se quer, e viabilizar a futura ampliação da produção de celulose, em uma etapa denominada pela empresa de Veracel II. O sistema de fomento florestal é muito interessante para as empresas deste circuito como um todo, mas a área plantada nesse sistema nunca vai superar as áreas de plantio próprio das empresas, pois mantendo-se como suas maiores auto-fornecedoras de matéria-prima, elas detém maior controle sobre o preço da madeira (monopólio), que, como já foi lembrado, consiste em um forte componente de competitividade, inclusive internacional.

Mas, atualmente, com os incentivos do governo federal, através do Plano Nacional de Florestas, é possível encontrar facilmente linhas de financiamento e crédito para os agricultores da região que se interessem em cultivar eucalipto, inclusive com linhas exclusivas para o PRONAF (Programa Nacional de Agricultura Familiar). O Banco do Nordeste, por exemplo, possui um fundo estadual específico para o plantio de eucalipto, o FNE Verde. Segundo este

\footnotetext{
${ }^{25}$ Fonte: Roteiro metodológico para elaboração de plano de manejo para reservas particulares do patrimônio natural (RPPN) - IBAMA, Ministério do Meio Ambiente.
} 
banco, o financiamento para atividades de reflorestamento tem tido muita procura na região, e é hoje a atividade agrícola mais rentável, superando os ganhos com o gado de corte, porém, empregando pouca mão-de-obra. De acordo com estudos realizados pelo Centro de Estudos e Pesquisas para o Desenvolvimento do extremo sul da Bahia (CEPEDES), a relação entre a área de cultivo necessária para geração de empregos é a seguinte:

As mudas de eucalipto que abastecem os plantios da empresa e de seus fomentados são produzidas no próprio viveiro da empresa, localizado em Eunápolis, que chegou a produzir, em 2004, dezessete milhões de mudas clonais de eucaliptos, além de duzentas e cinqüenta mil mudas de trezentas e cinqüenta espécies nativas diferentes. A idade média de uma árvore para o primeiro corte é de sete anos, sendo necessárias dez árvores para produzir uma tonelada de celulose.

A área de floresta necessária, por exemplo, para atingir a produção diária da fábrica corresponde a 31,6 hectares por dia. E o volume necessário de árvores para a produção de uma tonelada de polpa é de aproximadamente dez indivíduos.

A empresa cultiva, basicamente, duas espécies diferentes de eucaliptos, sendo uma mais resistente e com fibras de alto rendimento, e outra espécie de rendimento menor.

A primeira espécie é destinada à produção de celulose, enquanto a segunda é usada como combustível de queima para geração de energia na fábrica. As espécies nativas são usadas nos programas de recuperação de matas ciliares nas propriedades da Veracel.

A foto a seguir, mostra os funcionários trabalhando no viveiro da empresa, onde são cultivadas as mudas clonais de eucalipto. O viveiro está localizado na periferia de Eunápolis, à beira da BR-101, distante cerca de oitenta quilômetros do sítio da fábrica. 


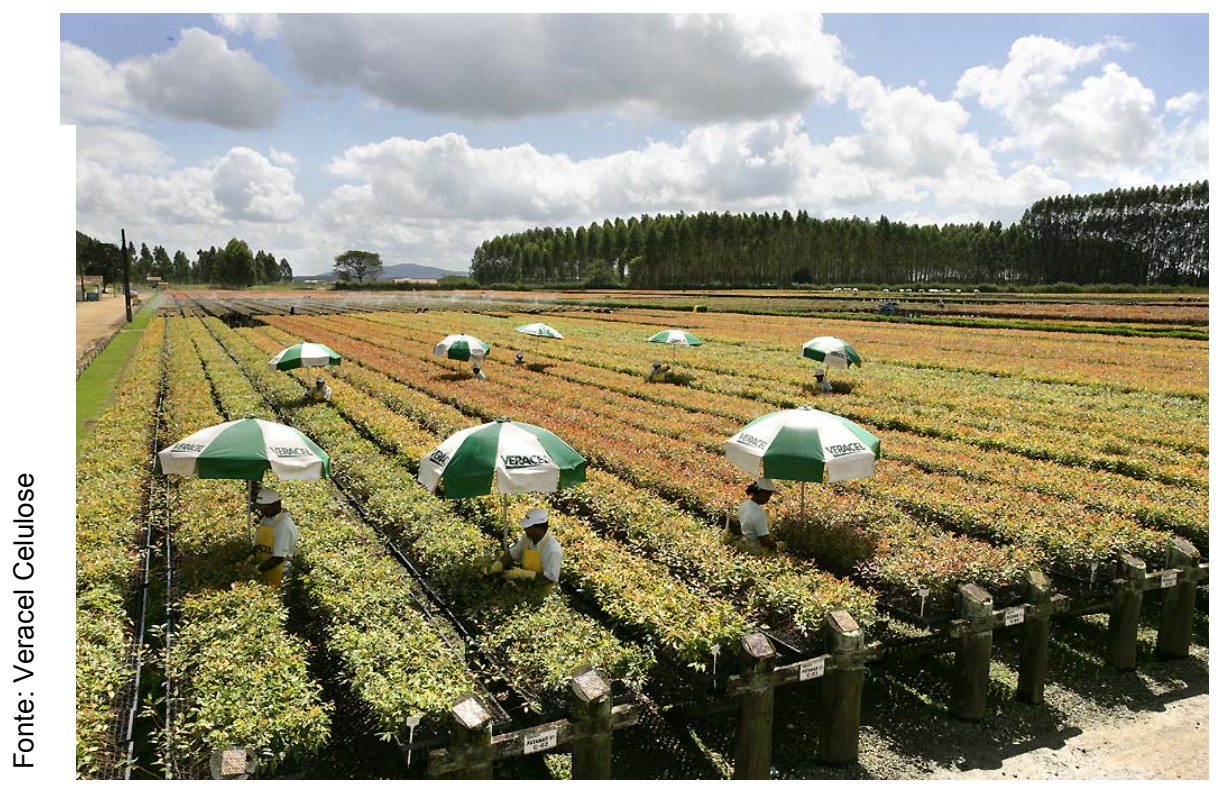

Figura 12 - Viveiro da Veracel

A empresa emprega hoje 3.639 funcionários (empregos diretos), lotados da seguinte forma:

Tabela 2 - Distribuição dos funcionários da Veracel

\begin{tabular}{|l|r|r|}
\hline Áreas & Próprios & Terceiros \\
\hline Florestal & 375 & 1836 \\
Industrial & 234 & 204 \\
Corporativa & 92 & 467 \\
Projeto & 10 & - \\
Apoio & - & 421 \\
Total & 711 & 2,968 \\
\hline \multicolumn{2}{|c|}{ Fonte: Veracel }
\end{tabular}

Durante a construção da fábrica, que durou dezessete meses, a Veracel chegou a empregar, no pico da obra, em Outubro de 2004, oito mil empregados (entre próprios e terceiros), sendo $50,14 \%$ da Bahia e $49,86 \%$ de outros estados e países. Nesse período foram contratadas e subcontratadas cento e sessenta e cinco empresas.

A Veracel também mantém investimentos em projetos sociais na região, mantidos com parte do financiamento do BNDES (correspondente a $\mathrm{R} \$ 21$ milhões, destinados a esse fim). Foram contempladas as áreas de saúde, educação e saneamento, em algumas das cidades que abrigam investimentos da Veracel. 
Atendendo às exigências internacionais de controle de efluentes, a empresa afirma que mantém um rigoroso controle ambiental de suas emissões. Uma parte dos resíduos sólidos (lodo biológico) é transformada em adubo na unidade de compostagem para ser comercializada. A estação de tratamento de resíduos líquidos, no entanto, mesmo sendo de última geração, consegue tratar, no máximo, cerca de $85 \%$ do efluente que retorna para o rio (ou seja, $15 \%$ de seus resíduos são lançados sem tratamento no Rio Jequitinhonha). Segundo a empresa, ainda não existe tecnologia que permita o re-uso da água na produção, mas o ponto de captação de água da Veracel foi instalado à jusante do local onde são jogados os efluentes.

A produção de celulose da Veracel é totalmente voltada para a exportação, sendo vendida para fábricas de papel da Europa, dos EUA e da Ásia. Cada uma das acionistas, a Aracruz e a Stora Enso, possui metade da produção. E a empresa sueco-finlandesa, por contrato, não pode revender a sua celulose para terceiros, devendo usá-la apenas em suas próprias fábricas, localizadas na Escandinávia e na China. A parte da produção que pertence à Aracruz é exportada para os EUA e para a Europa. A celulose produzida pela Veracel, que é de alta qualidade, se destina principalmente à fabricação de artigos de higiene pessoal, além de papéis para imprimir e escrever.

\section{Logística da produção}

A capacidade de produção da fábrica atual é de novecentas mil toneladas de celulose branqueada por ano, ou 2.543 toneladas por dia. Com a implementação da Veracel II, essa produção deve dobrar, chegando a quase dois milhões de toneladas por ano. Esta segunda etapa pode começar a operar dentro de cinco ou seis anos, dependendo da disponibilidade de madeira. Os custos, segundo a previsão da empresa, serão menores dos que os da implantação da empresa, além disso, serão necessárias menos terras.

Toda a área de floresta da empresa é coberta por um SIG (sistema de informação global) de gestão florestal, com softwares específicos para esse fim, que ajudam a manejar e organizar as áreas florestais, informando, por exemplo, a produção por classe de distância das fazendas, a distância média das unidades por corte, a taxa de incremento médio anual por fazenda ou o 
rendimento de madeira aproximado dos talhões. As áreas plantadas já estão organizadas e mapeadas de acordo com a espécie e o material genético, o espaçamento e a idade do plantio, o tipo e a declividade do solo, além da previsão de precipitação para cada mês.

A queima de madeira combustível torna a fábrica auto-suficiente em energia, alimenta um turbo gerador de grande capacidade (com um consumo de 126,6 MW/h, ou o equivalente ao consumo de uma cidade de quinhentos mil habitantes) e ainda gera uma sobra energética, que é vendida. Apenas durante a construção da fábrica foi usada energia da rede básica, provinda de Itapebi. A energia gerada abastece toda a fábrica e ainda supre a empresa química Eka Chemicals (sueca), instalada na mesma planta da Veracel, que produz o clorato e o dióxido de cloro, usados na fabricação da celulose. Os demais produtos químicos são comprados de outros fornecedores e estocados pela Eka.

A água utilizada na produção é retirada do Rio Jequitinhonha (sem qualquer tipo de cobrança, apesar de se tratar de um rio interestadual), o principal rio da região, que fica a seis quilômetros da fábrica. A Veracel consome cerca de $2900 \mathrm{~m}^{3} / \mathrm{h}$ (equivalente ao consumo de uma cidade de quarenta mil habitantes). Os efluentes do processo produtivo também são despejados no Rio Jequitinhonha, depois de passar pelo tratamento de lodo biológico, processado na unidade de compostagem. A capacidade de tratamento é de $2300 \mathrm{~m}^{3} / \mathrm{h}$ de efluente líquido.

A Veracel possui um modo de produção que as empresas chamam de "processo integrado", ou seja, todas as etapas da produção encontram-se espacialmente sequenciadas no sitio da empresa, além deste se manter pouco distante das áreas florestais e do terminal de embarque final da produção, otimizando o tempo do processo produtivo. Esta integração logística se traduz em expressivos ganhos de competitividade, que fazem da Veracel um dos maiores empreendimentos do circuito de celulose no mundo com essa configuração espacial. Além disso, o plantio e a colheita dos eucaliptos hoje são feitos mecanicamente, com o auxílio de máquinas desenvolvidas para este fim, empregando ainda menos mão-de-obra.

Podemos dizer que a fábrica da Veracel constitui um verdadeiro objeto técnico-informacional, pois “(...), graças à extrema intencionalidade de sua 
produção e de sua localização, eles já surgem como informação". (Santos, 1996:238)

Durante o processo produtivo, a cada vinte e quatro horas são feitas cerca de cento e oitenta viagens de caminhões, carregados de madeira, que chegam à fábrica. A distância média de transporte de madeira, desde as florestas até a fábrica, é de quarenta e sete quilômetros. Todos os caminhões são equipados com um chip eletrônico, que guarda informações sobre aquele carregamento de madeira (procedência, idade, tipo). Ao passar pela cancela da fábrica, essas informações são conferidas por computadores para liberar a entrada dos caminhões. As toras são empilhadas e organizadas conforme seus usos (queima ou fabricação de celulose).

A produção fabril da celulose é quase totalmente mecanizada, usando maquinário moderno e operado por funcionários especializados. Todas as etapas da produção, inclusive o despejo de efluentes, são rigorosamente monitoradas, usando um complexo sistema de câmeras e sensores espalhados pela planta da fábrica, observados vinte e quatro horas por técnicos na sala de controle operacional.

A capacidade de armazenamento de celulose pronta, no estoque da fábrica, é de quarenta e duas mil toneladas, que equivalem a dezesseis dias de produção. Os fardos de celulose, já embalados e carimbados com o nome da empresa dona daquele carregamento (Aracruz ou Stora Enso), são transportados em caminhões pela rodovia BA-275 (asfaltada para a utilização da empresa) até o terminal marítimo de Belmonte. A distância entre a fábrica e o terminal é de cinqüenta e sete quilômetros, e sua capacidade de armazenamento é quatorze mil toneladas, ou seis dias de produção. A celulose é transportada em barcaças até o terminal Portocel da Aracruz, em Barra do Riacho, norte do Espírito Santo, onde a celulose da Stora Enso é embarcada em navios transatlânticos. A distância entre o terminal da Veracel e o da Aracruz é de aproximadamente quinhentos quilômetros ou duzentas e oitenta milhas náuticas. As fotos abaixo ilustram algumas dessas etapas da produção. 


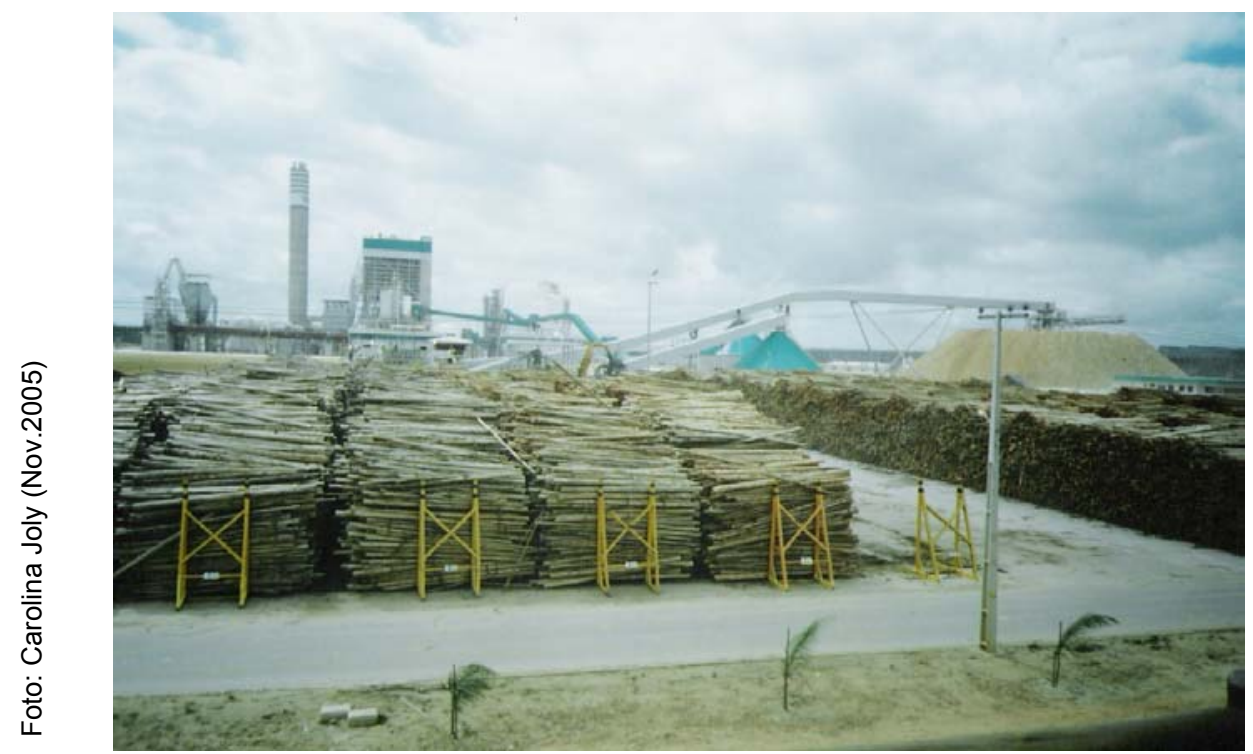

Figura 13 - Toras de eucalipto separadas para a queima e geração de energia.

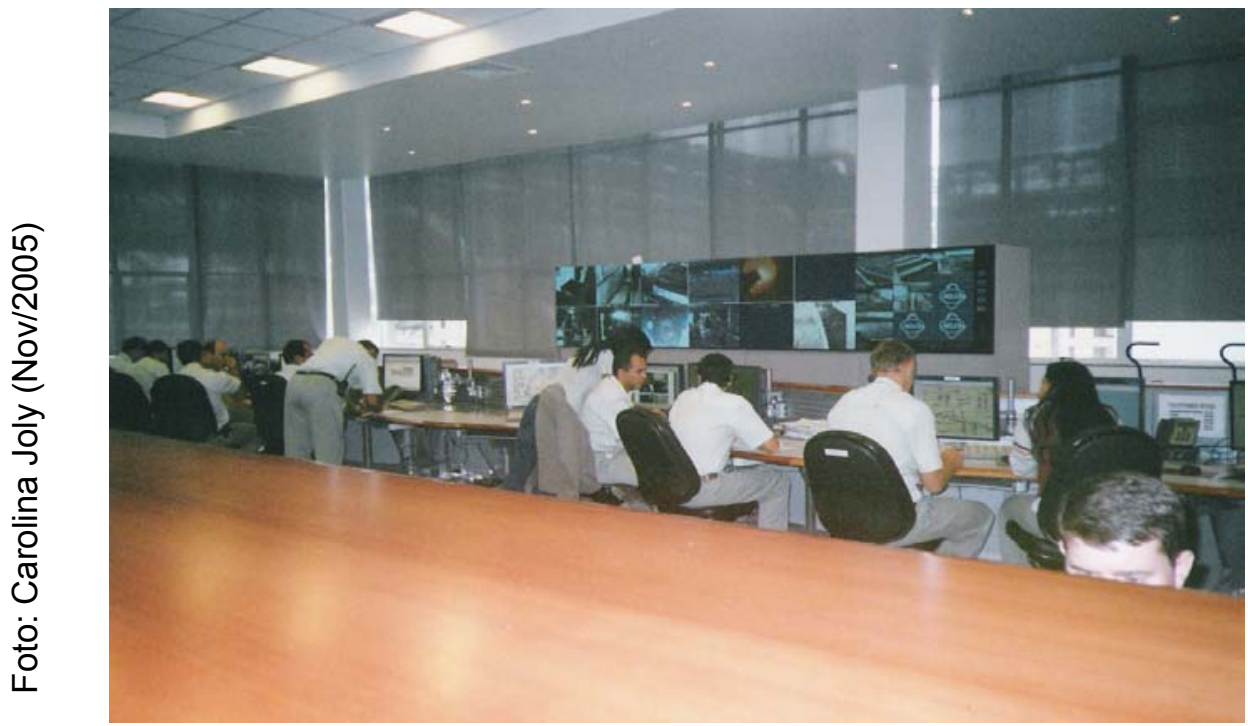

Figura 14 - Sala de controle e monitoramento de operações da Veracel 


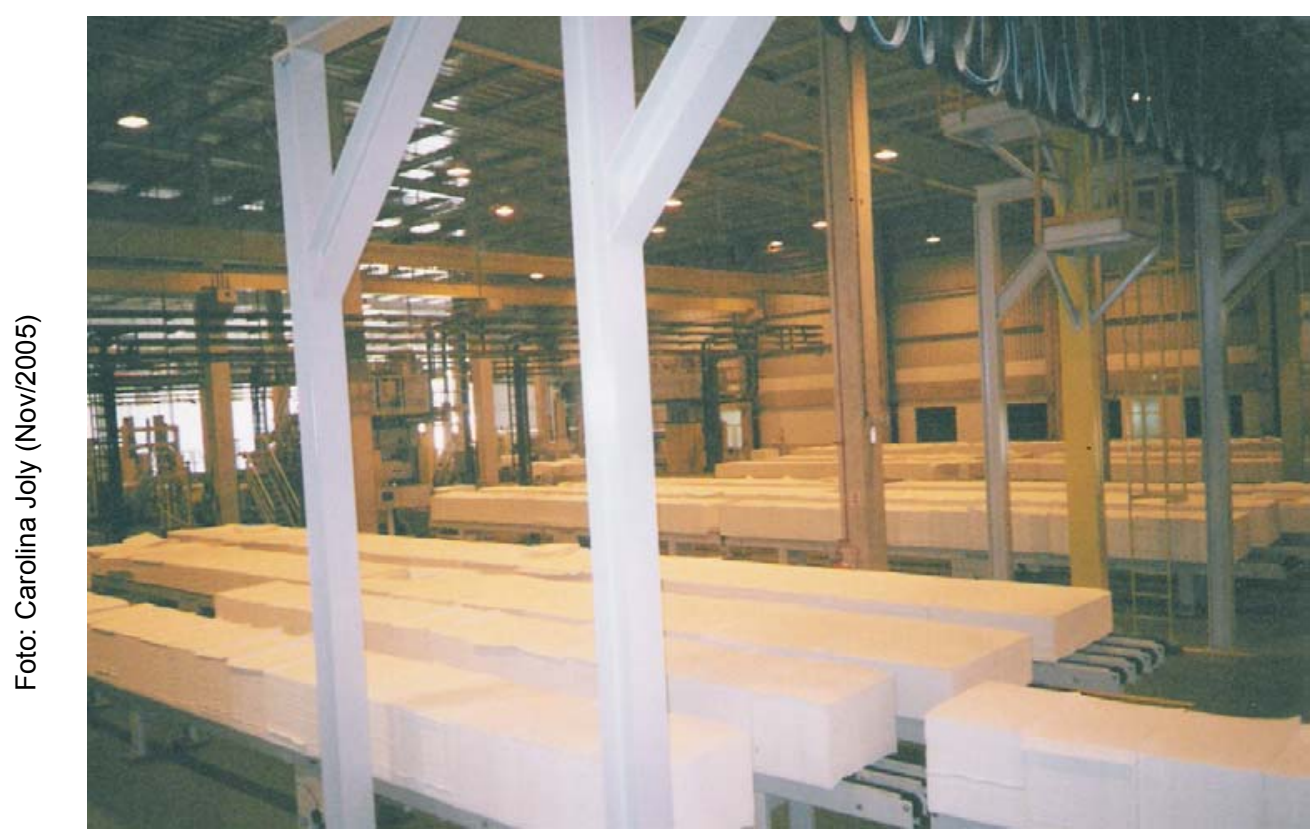

Figura 15 - Galpão de corte e embalagem dos fardos de celulose, já prontos para o transporte de caminhão até o terminal de Belmonte.

O sítio da fábrica constitui uma verdadeira ilha de excelência em sistemas de controle e informação, abrigando máquinas modernas e estruturas prediais inteligentes, mas cercada por paisagens rurais que não possuem nem mesmo luz elétrica.

\section{3) Território usado pela Veracel e suas principais transformações} sócio-espaciais

A chegada da especialização produtiva a um território, seja qual for o circuito espacial, traz consigo, inevitavelmente, a imposição de novos arranjos espaciais, alterando a organização do espaço vigente. Ou seja, traz desequilíbrios de toda sorte. $E$ as especializações calcadas no uso da terra e na monocultura, como o cultivo de eucaliptos, são ainda mais desestruturantes, pois interferem tanto na cidade como no campo. Dados mostram que no período entre 1991 e 2002 (período entre o início da compra de terras pela Odebrecht e a aprovação do empréstimo do BNDES concedido à Veracel) a população rural de Eunápolis sofreu uma redução de $59,37 \%$, enquanto a média nacional neste período foi de $28 \%{ }^{26}$

\footnotetext{
${ }^{26}$ Fonte: IBGE, em pesquisa feita pelo Centro de Estudos e Pesquisas para o Desenvolvimento do Extremo Sul da Bahia (CEPEDES).
} 
Tabela 3 - Evolução populacional de Eunápolis (2002)

\begin{tabular}{|c|c|c|c|c|}
\hline \multicolumn{2}{|c|}{ Município de Eunápolis } & Habitantes & Urbano & Rural \\
\hline Censo 1991 & & 70.545 & 63.540 & 7.005 \\
\hline Censo 2000 & & 84.120 & 79.161 & 4.959 \\
\hline Pop. Rural (1991): & $9,92 \%$ & Redução da pop. & (1991-2002): & $40,60 \%$ \\
\hline Pop. Rural (2002): & $5,89 \%$ & Redução da pop. & (1991-2002)nacional: & $28 \%$ \\
\hline
\end{tabular}

Fonte: CEPEDES (IBGE)

Atualmente, cerca de $73 \%$ da área agricultável do município de Eunápolis esta coberta por eucaliptos. ${ }^{26}$ Depois da chegada da empresa à região, na década de 90, o preço das propriedades rurais sofreram um forte processo inflacionário e muitos fazendeiros venderam suas terras. Logo, outra conseqüência imediata da chegada da empresa foi o aumento da concentração fundiária na região. O gráfico abaixo ilustra esta situação.

1985

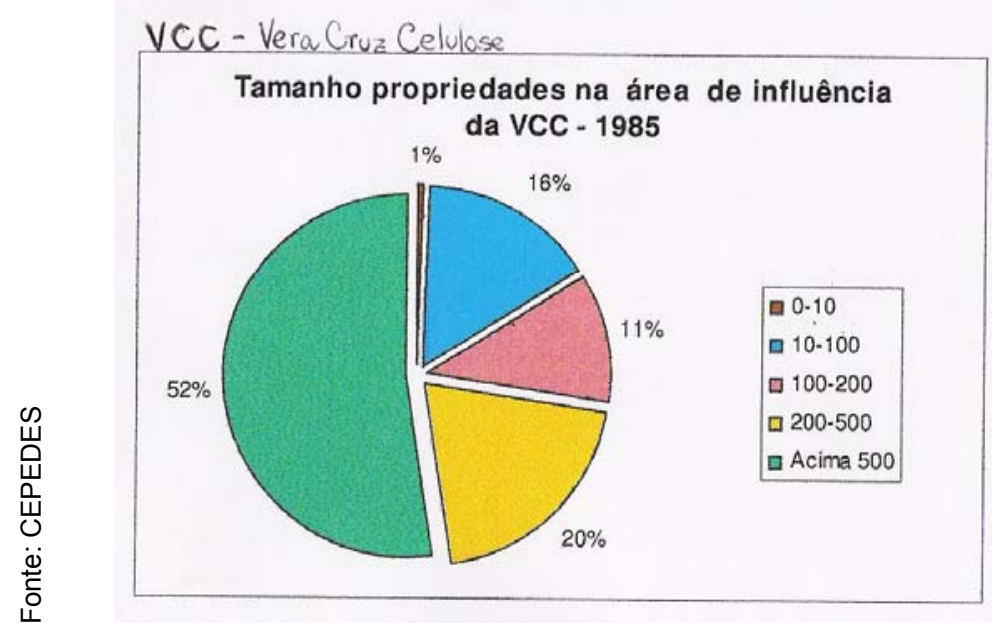

1995

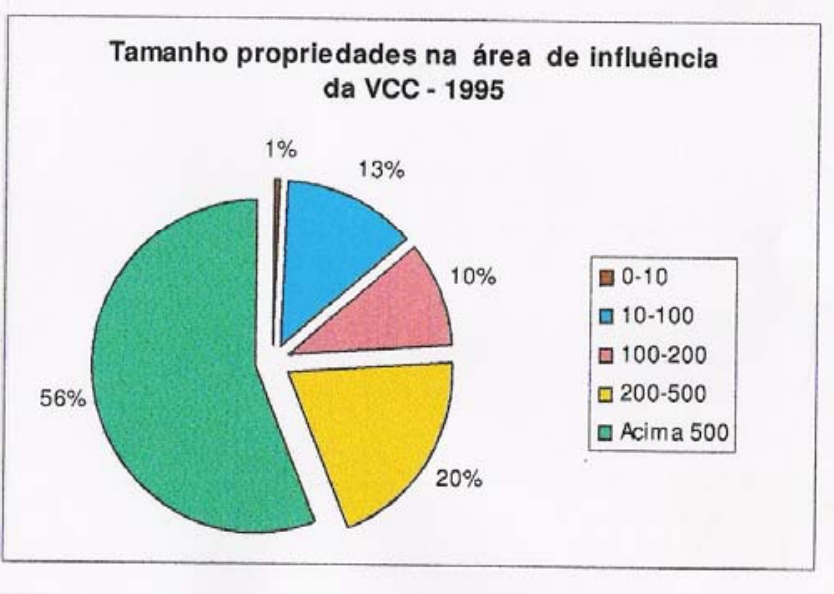

Figura 16 - Gráfico indicativo do aumento da concentração fundiária nos municípios sob influência da Veracel (antiga Veracruz), depois da chegada da empresa na região.

O desemprego no campo fez inchar a cidade e a periferia de Eunápolis cresceu, assim como os seus índices de violência. Dos empregos gerados pela empresa, com exceção do período de construção da fábrica, muitos não foram destinados aos habitantes de Eunápolis. Poucos são aqueles que conseguiram

\footnotetext{
${ }^{26}$ Fonte: dados fornecidos pelo material institucional da empresa Veracel.
} 
vagas na empresa, depois de concluída a fábrica. A justificativa da Veracel é a falta de qualificação da mão-de-obra local, com pouca escolaridade, como demonstrado na tabela 1 (página 72).

Muitos migrantes, vindos do norte de Minas Gerais, do Espírito Santo e do interior da Bahia, também chegaram a Eunápolis em busca de emprego durante a fase de construção da fábrica, e muitos não regressaram. No fim do período de obras, do dia para a noite, havia cerca de seis mil pessoas desempregadas, muitos sem ter meios de regressar às suas cidades, e acabaram por sobrecarregar os serviços públicos do município, como os hospitais e o abastecimento de água, por exemplo. Segundo o Secretário de Desenvolvimento do município, a taxa de desemprego na cidade, antes da construção da fábrica (2003) era de 19\%. Imediatamente depois de sua construção (nov. de 2005) esse número subiu para $28 \%$. De acordo com estudo do CEPEDES (2005):

A população urbana cresceu por conta do êxodo e relacionada à propaganda institucional das empresas da monocultura do eucalipto e dos governos estadual, federal e municipal que anunciaram a criação de 12 mil empregos segundo reportagem de $A$ Tarde em 24 de julho de 1994, o que chamou a atenção de um número muito grande de trabalhadores desempregados do Estado da Bahia e estados vizinhos como nordeste do Estado de Minas Gerais e norte do Estado do Espírito Santo. Inclusive houveram relatos que vários trabalhadores estavam chegando dos municípios do norte da Bahia, como Juazeiro e até mesmo de Pernambuco, como Petrolina, num raio de distância de aproximadamente mil quilômetros. (Relatório CEPEDES, 2005)

As serrarias da região também tiveram que despedir funcionários, pois o fornecimento de madeira, vendido pela Veracel, foi repentinamente interrompido depois do início da fabricação de celulose. Esse desabastecimento repercutiu também no campo, pois não havia madeira nem mesmo para a confecção das caixas de embalar frutas, dificultando o seu transporte e comercialização.

O comércio de Eunápolis também sofreu, pois os comerciantes investiram na diversificação e em ampliações dos estabelecimentos, esperando uma injeção de capital com a chegada dos executivos e funcionários da empresa à cidade. No entanto, estes preferiram não fixar residência em Eunápolis, e sim em Porto Seguro, apesar da distância diária de oitenta quilômetros a ser percorrida até a fábrica.

As rodovias que cortam a cidade (a BR-101 e a BR-367) sofreram um aumento brutal no volume de tráfego, especialmente de caminhões, 
transportando madeira e celulose em direção ao Espírito Santo, até que o terminal portuário de Belmonte-BA ficasse pronto. Além de deteriorar mais rapidamente as condições das rodovias, houve um significativo aumento do número de acidentes nessas estradas, segundo informou em entrevista o engenheiro florestal Florisval Lima.

Para a população de Eunápolis, que sempre conviveu com a carência dos serviços públicos básicos (saúde, educação, saneamento) e que viu as desigualdades aumentarem em tão pouco tempo, as parcas ações realizadas pela empresa, a título de cumprir com sua responsabilidade socioambiental, representam muito pouco. Como afirmou em entrevista o Padre Eclésio, "o sentimento geral da população é de angústia social".

Em entrevista, tanto o Secretário do município, como o engenheiro e o padre afirmaram que a vinda da empresa trouxe benefícios inegáveis, entre eles os empregos, o aumento na arrecadação de impostos e a queda expressiva do desmatamento nas áreas ainda cobertas pela Mata Atlântica na região. Mas foram unânimes quanto ao entendimento de que a empresa trouxe mais problemas do que soluções para a sociedade.

Como é possível perceber, a chegada do circuito espacial produtivo de celulose à região de Eunápolis foi realmente impactante e transformadora, tanto do ponto de vista das novas relações que se estabeleceram como também sobre o aspecto da paisagem local, agora recoberta por milhares de hectares de eucaliptos. Dentre as novas relações estabelecidas pela especialização produtiva implantada, especialmente por se tratar de um produto semi-industrializado voltado para a exportação como a celulose, está o atrelamento de todo o funcionamento deste circuito, logo, desta região, desse lugar, ao mercado internacional, e, por conseguinte, à sua instabilidade e vulnerabilidade intrínsecas. Como nos lembram Santos e Silveira (2001),

Alargam-se os contextos ao mesmo tempo em que as regiões perdem o controle sobre o que nelas acontece, contribuindo para uma verdadeira fragmentação territorial. As novas vocações regionais são amiúde produtoras de alienação, pela pressão da ordem global sobre as populações locais. (Santos e Silveira, 2001:106).

Por esse motivo o estudo dos circuitos espaciais de produção, vistos sob a óptica da escala do lugar, é tão importante, pois revela as realidades escondidas pelas estatísticas de produção do produto interno bruto (PIB), dos 
superávites, de índices da balança comercial, etc. O estudo da especialização produtiva na região de Eunápolis constitui um bom exemplo de investigação do que realmente ocorre no território brasileiro, de situações veladas pela econometria do comércio exterior. O entendimento das motivações que levaram a Aracruz e a Stora Enso a investirem no município baiano de Eunápolis, pode ter pouco haver com o compromisso do desenvolvimento regional, como afirma o material institucional da Veracel.

Logo, muitos circuitos espaciais hoje são, em muitos casos, reveladores dos "espaços nacionais da economia internacional" (Santos, 1994), pois estão cada vez mais voltados para o mercado externo, em detrimento dos reais interesses daqueles que vivem o cotidiano do lugar e da região.

De acordo com Arroyo (2006),

As frações do território vinculadas ao mercado externo estão em permanente transformação por via da ação de empresas e instituições que operam, ou se projetam, na escala mundial. Pretendem, assim, suprimir todo obstáculo à livre circulação das mercadorias, das informações e do dinheiro a partir de uma base material (de ordem técnica: portos, aeroportos, rodovias, ferrovias, hidrovias, armazenagens, etc.) que sirva para regular as novas condições. (Arroyo, 2006:81)

É temerário, portanto, deixar que uma parte considerável do território baiano, especialmente numa região marcada por séculos de desigualdades como o Nordeste, seja, de novo, destinada a uma monocultura voltada para o mercado externo. Mais grave que isso é a permissividade das relações estabelecidas entre as empresas e o poder público em todos as esferas, vendo que este hora se antecipa, hora obedece aos desígnios dos investidores, abrindo mão de seu predicado mais importante, que é o de planejador, e transferindo-o para as empresas.

\section{Considerações finais}

A promessa do desenvolvimento e do emprego, tão desejados pela população da região, que há anos esperava a indústria de celulose se instalar na cidade, acabou por aprofundar as desigualdades e desapontar a sociedade, de maneira geral. Neste início de século XXI, assim como Eunápolis, muitos outros lugares do planeta estão abrigando ou vão abrigar investimentos, de diversos circuitos produtivos, extremamente seletivos como o da Veracel. A ideologia do chamado desenvolvimento local, difundida pelas agências 
internacionais de crédito (como ○ Banco Mundial, o Fundo Monetário Internacional, o Banco de Desenvolvimento Europeu, etc) seduz o poder público e convence o lugar de que todos ganharão com a chegada de um grande investimento privado.

Como no caso da Veracel, vimos que, de fato, há um crescimento inegável da economia local, gerando empregos (especialmente os terceirizados) e a arrecadação de tributos locais. Contudo, o grau de racionalidade produtiva que um empreendimento como este exige, transforma de tal modo a organização espacial vigente que ele acaba por moldar o território à sua maneira, sem que precise se relacionar com o seu entorno imediato, onde moram as relações cotidianas do lugar $e$ onde as conseqüências dessa transformação são vivenciadas.

Com o empreendimento da empresa Bahia Sul Suzano (do mesmo porte da Veracel), instalada há mais de dez anos numa região próxima a de Eunápolis e de semelhantes aspectos socioeconômicos, não foi diferente. Segundo pesquisa do relatório de consultoria, encomendado pelo Ministério do Meio Ambiente, sobre os conflitos socioambientais relacionados ao reflorestamento, a região de Teixeira de Freitas-BA, onde se instalou em 1992 a Bahia Sul, enfrentou problemas relacionados a

aspectos fundiários (concentração fundiária, disputa de terras), migração desordenada, desagregação das comunidades tradicionais da região, poluição de impactos em ecossistemas terrestres e aquáticos ameaçados de extinção e/ou protegidos por lei, questões trabalhistas e impactos em outras atividades econômicas, principalmente o turismo. (Fanzeres, 2005:94)

Logo, estes empreendimentos não devem (e nem é o papel deles) ser reconhecidos como grande solução para o saneamento das mazelas seculares que assombram muitos lugares, inclusive Eunápolis, como a concentração fundiária, a violência no campo, o desemprego, a queda da qualidade de vida na cidade. A finalidade primeira das empresas é gerarem lucro, com o menor gasto possível. Sendo assim, as oportunidades de melhora das condições socioeconômicas de uma região, ou de um lugar, que já abriga esses investimentos, podem ser de fato concretizadas, principalmente, através de políticas públicas.

Contudo, não existem atualmente políticas públicas voltadas para os problemas enfrentados pela população, de modo geral, como já houve, em 
âmbito federal, durante a "era do cacau", quando o governo da Bahia cobrava taxas dos exportadores para custear as melhorias na infra-estrutura urbana da região. Nos anos 60, o governo federal chegou a criar, em Ilhéus, também com recursos dos impostos da exportação de cacau, a Escola Média de Agricultura da Região Cacaueira (EMARC), a fim de formar técnicos e agrônomos especializados na cultura do cacau, qualificando a mão-de-obra local. São contrapartidas legítimas que o poder público deve reivindicar para atenuar os impactos negativos que a especialização produtiva traz aos lugares.

Hoje, os governos afirmam que não podem taxar as grandes empresas, ao contrário, é necessário desonerar ao máximo os investimentos, sob a ameaça de que as empresas migrem para outros lugares. Ou então, afirmam que não podem onerar a produção, pois o produto perderá competitividade no mercado internacional (terá um preço maior) e as conseqüências para a balança comercial do país serão terríveis, porque pagaremos um pouco menos dos serviços (juros) da nossa dívida externa.

Mas no caso da Veracel, especificamente, é muito pouco provável, como já foi dito anteriormente, que esta empresa, depois de ter comprado e reflorestado mais de cem mil hectares de eucalipto na região, venha a deixá-la tão cedo. Ao contrário, já planeja sua expansão em breve, com a Veracel II. A empresa não deixará a região, mesmo que o governo estabeleça cobranças de contrapartidas (não necessariamente através de impostos), onde os recursos poderão ser empregados em investimentos que diversifiquem a economia e que dêem qualificação à mão-de-obra local. O incentivo à criação de um polo moveleiro, por exemplo, ou à prática do uso misto do solo, cultivando outras culturas juntamente com o plantio do eucalipto, são algumas sugestões.

Os habitantes da região de Eunápolis, hoje desapontados com a relação distante que a Veracel mantém com o lugar, cobram da empresa ajuda para amenizar os problemas, guardando, talvez, os resquícios das relações paternalistas que o coronelismo plantou na região. O poder público municipal, possivelmente por motivos eleitoreiros, se diz decepcionado com a empresa, que depois de instalada não resolveu os problemas sócio-econômicos da região, que só pioraram. E a Veracel, por sua vez, afirma que paga devidamente seus tributos e cumpre à risca todas as exigências dos estatutos de responsabilidade sócio-ambiental, não competindo a ela esse dever. Com a 
futura expansão da fábrica, quando novamente muitos migrantes se dirigirão para Eunápolis, essas relações, provavelmente, ficarão ainda piores.

Assim, mais do que se limitar a questionar o volume absurdo de papel consumido pelos países desenvolvidos, como fazem as ONG's ligadas aos temas da monocultura do eucalipto e empresas do circuito, esta pesquisa procurou mostrar que é preciso uma reflexão mais aprofundada. É preciso repensar, com urgência, novas formas de implantação de empreendimentos desta magnitude, que hoje só necessitam de um estudo de impacto ambiental (licenciamentos, áreas de proteção, tratamento de efluentes) e um plano de operações (transporte, rotas, distâncias) para ser legalmente aprovado. Criar mecanismos de compensação, exigindo das grandes empresas apoio financeiro para investir em setores que a sociedade civil organizada indique (educação, saúde, saneamento, transporte) e deixando a administração nas mãos do poder público (diferenciando das ações de responsabilidade social), constitui uma sugestão para, ao menos, tentar diminuir as desigualdades sociais nos lugares onde se instalam os grandes empreendimentos, que só as aprofundam. $\mathrm{Na}$ realidade, o papel do Estado, em relação aos grandes investimentos privados no país, também precisa ser revisto.

O Brasil, que possui tecnologia e indústrias de ponta para produzir papel, de qualidade, pronto para o consumo final, optou por especializar sua matriz exportadora na produção da chamada "celulose de mercado" (na qual o país se tornou um dos maiores produtores mundiais), que consiste na simples produção da pasta de celulose, comprada pelas fábricas estrangeiras de papel propriamente. Além disso, permite que um mesmo grupo empresarial, como a Aracruz Celulose, assim como outros, detenha centenas de milhares de hectares de terras em seu poder. Este dado, em si, já é um expressivo fator gerador de desigualdade.

Porém, o fato mais questionável dessa política econômica, que optou por exportar o produto de menor valor agregado, é permitir que os recursos nacionais subsidiem a "produção com venda casada" de uma empresa estrangeira, como a Stora Enso faz, através da Veracel. Ou seja, a Veracel (que tem $50 \%$ dos ativos pertencentes à multinacional) exporta, a custos mínimos, matéria-prima para a própria Stora Enso, líder mundial na produção de papel. 
Em outras palavras, em troca da geração de alguns empregos, o BNDES custeia os lucros da multinacional escandinava.

Portanto, a tomada de consciência do lugar sobre o que ocorre no seu território se faz urgente. É preciso que a população se organize, fortaleça as instituições independentes que, apesar de poucas, já existem na região do extremo sul da Bahia, (como o CEPEDES e a Rede Alerta) para então pressionar os governos a tomarem medidas que beneficiem a sua população e não somente as empresas. O fato de, nas eleições de 2006 para o governo do estado da Bahia, o grupo político que ocupou o poder nos últimos dezesseis anos, perdeu, ainda no primeiro turno, para a oposição, pode indicar algum movimento da população no sentido de se conscientizar, ou pelo menos de desejar uma mudança.

É preciso que o lugar desperte e veja o poder da sua força de transformação, que pode ajudar a fortalecer os processos democráticos numa das regiões do país que ainda convive com os espólios da política coronelista. Afirmar que a resistência mora no lugar pode parecer quixotesco, mas é somente nele que se abriga o desejo de que a realidade mude, e isso já é um início.

\section{Referências bibliográficas}

ALVARADO, Raquel. La globalization perversa y el conflicto de las plantas de celulosa: ¿ un caso de manual? Mimeo. Buenos Aires: Universidad de Buenos Aires, 2006. Não paginado.

ARROYO, M. M. Dinâmica territorial, circulação e cidades médias. In: SPOSITO, E. S.; SPOSITO, M. E. B.; SOBARZO, O. (Orgs.). Cidades médias produção do espaço urbano e regional. São Paulo: Expressão Popular, 2006. 71-85 p. (Geografia em Movimento).

BAHIA (Estado). Plano Pluri-anual para os exercícios de 2000 a 2003.

Secretaria Estadual de Planejamento do estado da Bahia. Salvador, 2000. 170 p. (Disponível em: < http:// www.seplan.ba.gov.br Acesso em: 12 de Janeiro de 2005). 
BRASIL (país).Temas conflituosos relacionados à expansão da base florestal plantada e definição de estratégias para minimização dos conflitos identificados. Coordenadora Anna Fanzeres. Ministério do Meio Ambiente. Secretaria de Biodiversidade e Florestas. Brasília, 2005. 261p. (1 cd rom).

BRASIL (país). Roteiro metodológico para elaboração de plano de manejo para reservas particulares do patrimônio natural (RPPN), Ministério do Meio Ambiente. Instituto Brasileiro do Meio Ambiente e dos Recursos Naturais Renováveis (IBAMA). Brasília, 2004. 97 p. (Disponível em: <http:// www.mma.gov.br Acesso em 20 de Janeiro de 2007).

BRASIL (país). Configuração atual e tendências da rede urbana. Série caracterização e tendências da rede urbana do Brasil. v. 1. Ministério do Planejamento, Orçamento e Gestão. Instituto Brasileiro de Geografia e Estatística. Brasília, 2002. 396 p.

CANO, W. Desequilíbrios regionais no Brasil: alguns pontos controversos. In: BELLUZZO, L. G. M.; COUTINHO, R. (Orgs.). Desenvolvimento capitalista no Brasil: ensaios sobre a crise. 4. ed.v. 2. Campinas: Ed. da Unicamp, 1998. 275293 p. (Universidade Estadual de Campinas, Instituto de Economia)

CATAIA, M. A alienação do território - o papel da guerra fiscal no uso, organização e regulação do território brasileiro. In: SOUZA, M. A. A. (Org.). Território Brasileiro - usos e abusos. Campinas: Edições Territorial, 2003. 397-407 p.

CENTRO DE ESTUDOS E PESQUISAS PARA O DESENVOLVIMENTO DO EXTREMO SUL DA BAHIA. Relatório de pesquisa dignóstica da situação socioeconômica do entorno da fábrica de celulose na microrregião de Eunápolis. Coordenador Cristiano Raykil Pinheiro. Eunápolis, 2005. Não paginado. (Disponível em: <http:// www.cepedes.org.br Acesso em: 17 de Agosto de 2006).

DALCOMUNI, S. M. A implantação da Aracruz Celulose no Espírito Santo - principais interesses em jogo. 1990. 258 p. Dissertação (Mestrado em Economia) - Instituto de Ciências Humanas e Sociais, Universidade Federal Rural do Rio de Janeiro, Itaguaí, 1990.

FAUSTO, B. História do Brasil. 8. ed. São Paulo: Edusp, 2000. 657 p. 
FERREIRA, S. R. B. Da fartura à escassez: a agroindústria de celulose e o fim dos territórios comunais no extremo norte do Espírito Santo. 2002. 226 p. Dissertação (Mestrado em Geografia Humana) - Faculdade de Filosofia, Letras e Ciências Humanas, Universidade de São Paulo, São Paulo, 2002.

GARCEZ, A. N. R.; FREITAS, A. F. G. Bahia cacaueira: um estudo de história recente. Revista de Estudos Baianos, Salvador, n. 11, p. 12-26, 1979. (Universidade Federal da Bahia).

MAMIGONIAN, A. O processo de industrialização em São Paulo. Boletim Paulista de Geografia, São Paulo, n. 50, p. 83-101, Mar. 1976. (Associação dos Geógrafos Brasileiros - Seção São Paulo)

MARCOVITCH, J. Pioneiros \& empreendedores - a saga do desenvolvimento no Brasil. v. 2, São Paulo: Edusp, 2005.193-225 p.

PIQUET, R. Cidade-empresa. Presença na paisagem urbana brasileira. Rio de Janeiro: Jorge Zahar Editor, 1998.113-128 p.

PONTES, B. M. S. As mudanças no processo capitalista e suas repercussões nas cidades médias nordestinas. In: SPOSITO, E. S.; SPOSITO, M. E. B.; SOBARZO, O. (Orgs.). Cidades médias - produção do espaço urbano e regional. São Paulo: Expressão Popular, 2006. 327-346 p. (Geografia em Movimento).

SANTOS, M. Zona do cacau - introdução ao estudo geográfico. 2. ed. São Paulo: Companhia Nacional, 1957. 110 p.

, Metamorfoses do espaço habitado - fundamentos teóricos e

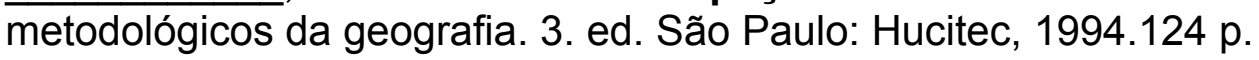

A natureza do espaço - técnica e tempo, razão e emoção. São Paulo: Hucitec, 1996. 308 p.

, Espaço e método. 4. ed. São Paulo: Nobel, 1997. 88 p.

, O retorno do território. In: SANTOS, M.; SOUZA, M. A. A.; SILVEIRA, M. L. (Orgs.). Território: globalização e fragmentação. 4. ed. São Paulo: Hucitec,1998. 15-20 p. (Associação nacional de pós-graduação e pesquisa em planejamento urbano e regional - ANPUR). 
, Modo de produção técnico-científico e diferenciação espacial.

Revista Território. Rio de Janeiro, ano IV, n. 6, Jan./Jul., 1999. 5-20 p.

(Universidade Federal do Rio de Janeiro).

, Por uma outra globalização - do pensamento único à

consciência universal. 3. ed. Rio de Janeiro: Record, 2000. 174 p.

SANTOS, M.; SILVEIRA, M. L. O Brasil - território e sociedade no início do século XXI. Rio de Janeiro: Record, 2001. 471 p.

\section{Artigos de jornal}

Folha de S. Paulo, São Paulo, 30 abr. 2006. Folha Dinheiro.

AMÉRICA do Sul é o eldorado da indústria de papel e celulose. Correio Popular, Campinas, 04 jun. 2006. Caderno Economia.

ARACRUZ investe no RS US\$1,3 bi em nova fábrica. Folha de S. Paulo, São Paulo, 30 jun. 2006. Folha Dinheiro, p. B 9.

Folha de S. Paulo, São Paulo, 12 jul. 2006. Folha Dinheiro.

Gazeta Mercantil, São Paulo, 09 jun. 2003.

CAPACIDADE chega ao limite e indústria já prevê reajuste. Folha de S. Paulo, São Paulo, 01 ago. 2006. Folha Dinheiro, p. B 1.

Revista Cerrado Rural, Salvador, dez. 2005.

On line

BRASIL. Ministério do Meio Ambiente. Disponível em: <http:// www.mma.gov.br Acesso em: 15 mar. 2006.

BRASIL. Ministério do Desenvolvimento, Indústria e Comércio Exterior. Banco Nacional de Desenvolvimento Econômico e Social. Disponível em: <http:// www.bndes.gov.br Acesso em: 21 ago. 2005. 
BRASIL. Ministério do Desenvolvimento, Indústria e Comércio Exterior. Instituto Brasileiro de Geografia e Estatística. Disponível em: <http:// www.ibge.gov.br/home Acesso em: 23 nov. 2005. 